\title{
الثناكرية ودورهم فى الدولة العباسية فى القرن الثالث الهجرى
}

د. محمد السيد فياض

\section{الثاكرية ودورهم فى الاولة العباسية فى القرن الثالث الهجرى(')}

تأتى فئة الثاكرية كو احدة من أطر اف معادلة القوة العسكرية والسياسية فى تاريخ الدولة العباسية إبان فترة الدراسة، وتأتى خصوصية هذه الفئة أنها ساهمت فى كثير من الأحيان فى تغيير مبزان القوى، فعملو اكقوات خاصة() أو كمرتزقة، أو فى الحر اسة الشخصية، متعاملين بكل بر اجماتية فى تعاطيهم مع كافة الأحداث السياسية التى انخرطو ا فيها كما سبتضح من خلا الدراسة .

وبطبيعة الحال فعلينا أولاً أن نناقش مصطلح الدراسة هذا المصطلح المرتبط بفرقة عسكرية ذات أصول متعددة ، لم تنتم لقائد بعينه، ولا جنس محدد، والشاكرية كلمة فارسية تعنى الخدم، وكان هؤلاء الأفراد يقومون لقادته بالخدمات العسكرية ذاتها التى كان يقوم بها الفرسان لملوكهم فى العصور الوسطى فى أوربا، وظل هؤلاء الأفر اد فى خدمة قادته الذين عينوا مو الى للحاكم ()، وكان

(') اقتصر الباحث فى عنوان الدر اسدة على كلمة دورهم ( أى دور الثشاكرية) وذلك لتداخل الأدو ار التى قامت

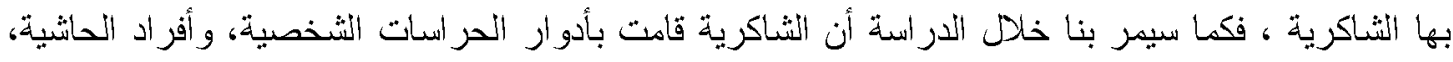

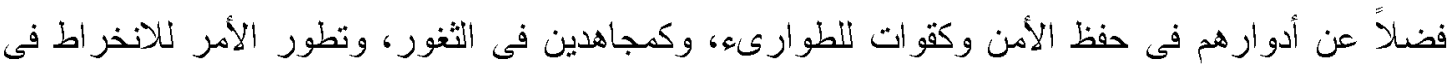

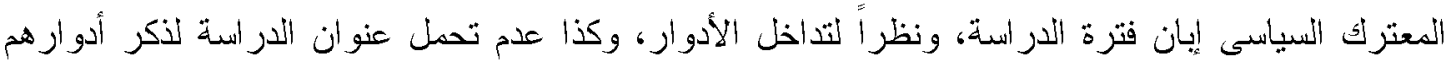

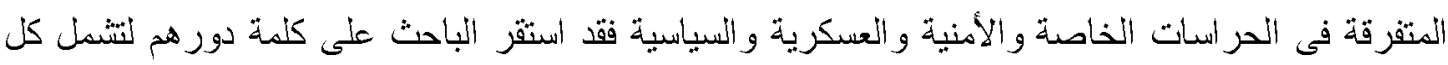
هذه الأدوار، أما فيما يتعلق بعدم ذكر سنوات محددة للاراسة فعلينا أن نقر بقلة المادة العلمبة المتعلقة

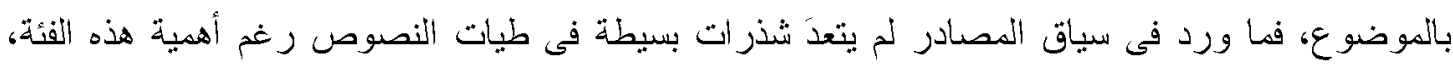

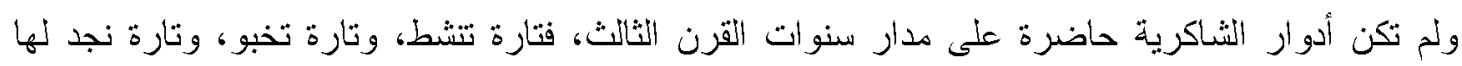

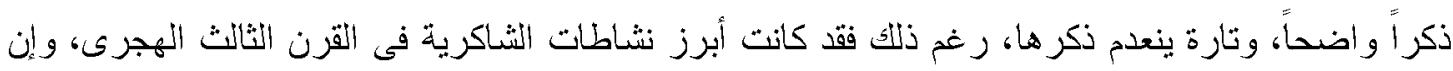

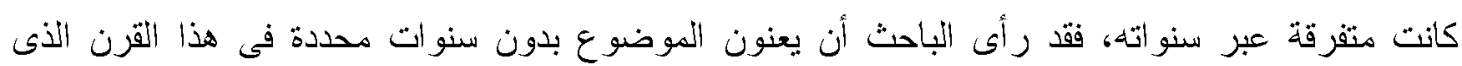

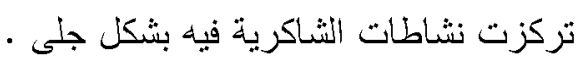
KHALIL, ATHAMINA, AL-SHAKIRIYYA, The Encylopadeia of Islam, Vol. IX, Leiden, (") $1997, p 249$.

(ץ) محمد عبد الحى محمد شعبان: الدولة العباسية، الفاطميون، الأهلية للنشر والتوزيع، بيزوت، (919)،

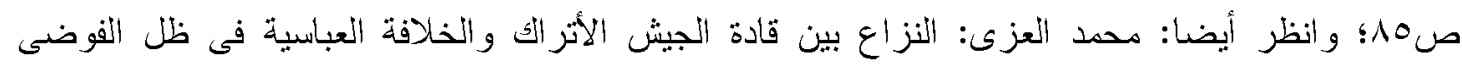

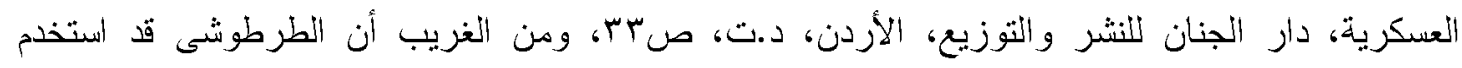

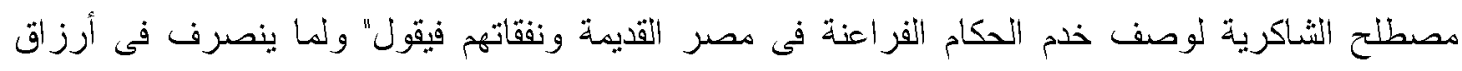


التعبيز الذى استعمل لهذا المنصب هو الغلام جمعها غلمان وهو الترجمة العربية الدقيقة للكلمة الفارسية "شاكر" أو "جاكر" ثم عُربث هذه الكلمة فيما بعد بالثاكرية (')، وتعنى العبد أو المسخر، وهو وتُطلق على التابع (r)، وحسب طروحات أخرى فسرت مصطلح الثاكرية بالخدم، وهم من المرتزقة المرتبطين بالو الى أو القائد، ويشكلون جزءً من مو اليه و غلمانه(")، وفسر ها آخرون بأن معناها الأجير المستخدم (๕)، وحسبما يذكر الجاحظ قائلاً" ألا ترى أن اسم الثاكرية وإن خالف فى الصورة و الهجاء اسم الجند فإن المعنى فبهما ليس ببعيد؛ لأنهم برجعون إلى معنى واحد وعمل واحد ، والذى إليه

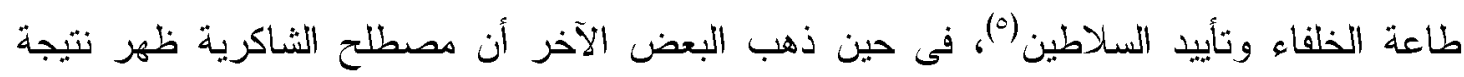
لتعدد عناصر الجيش واختلاف كل عنصر عن الآخر فى اللغة والوطن الأمر الذى أثز فى انقسام الجيش إلى عدد من الطو ائف و الفرق كان منها الثاكرية. (ٓ)

الأونياء المرسومين بالسلاح ، وحملته - يقصد حملة الفرعون- من الثشكرية والغلمان وأثياعهم" انظر :

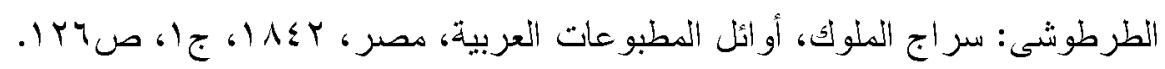

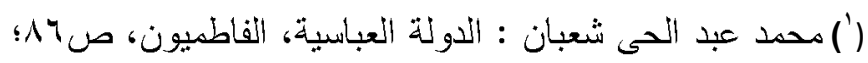
KHALIL , AL-SHAKIRIYYA, The Encylopadeia of Islam, ,p249.

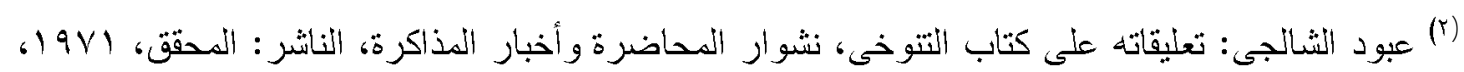

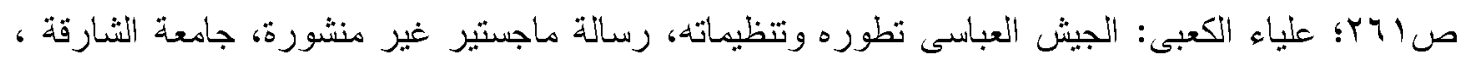
.1790 ص. T. PV

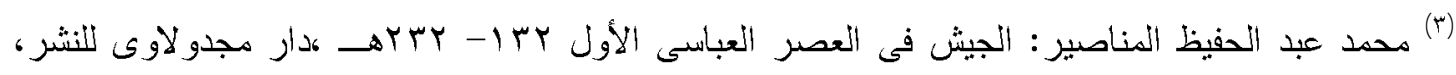

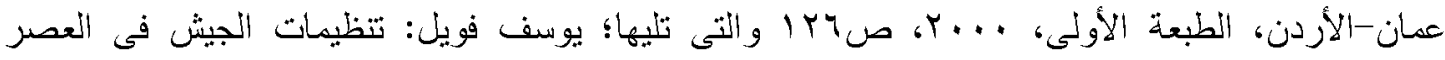

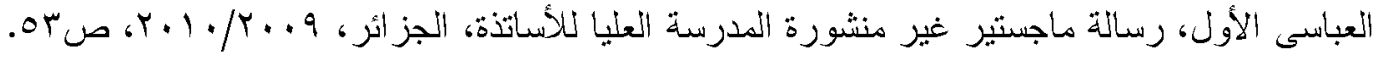

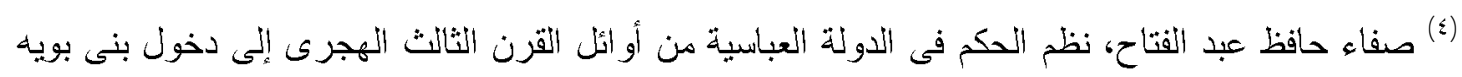

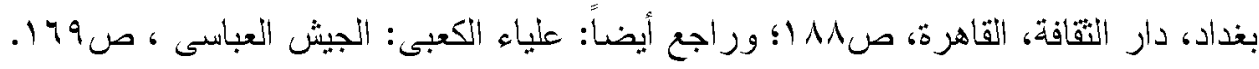

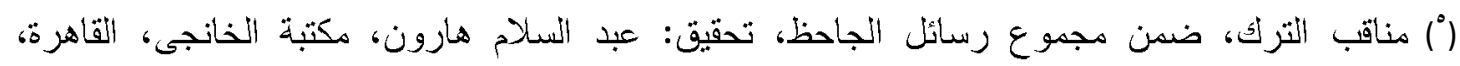

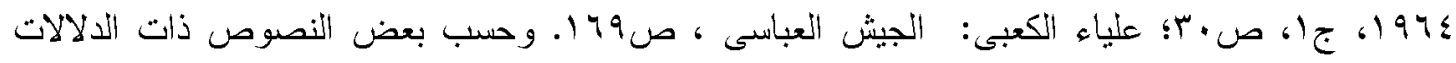

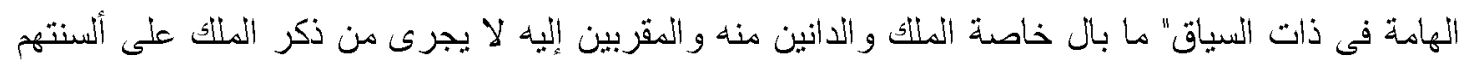

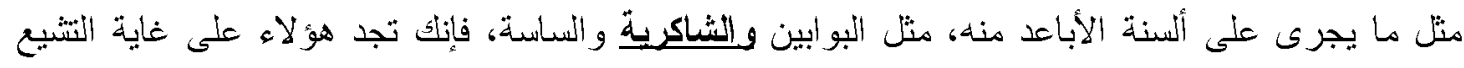

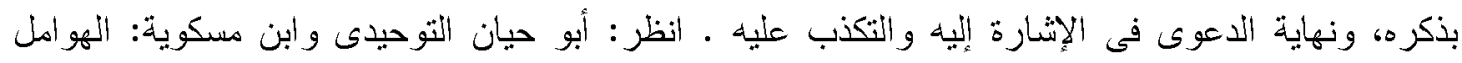

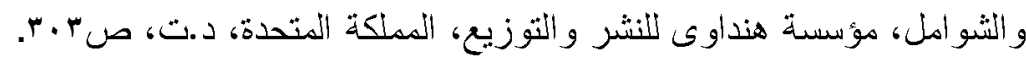

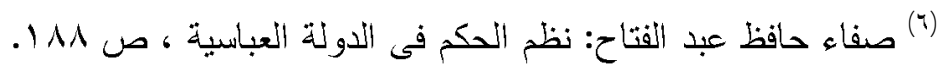


أما عن تاريخانية ظهور المصطلح، فيمكننا أن نستطلع أو ائل ذكره فى بعض النصوص، فقد ذكر

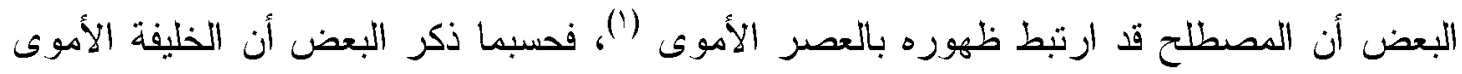

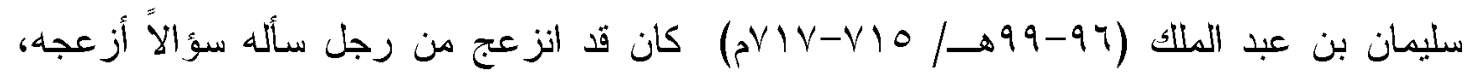
وحسبما أوردته بعض النصوص أنه ما إن بدت مظاهز الانزعاج على وجه الخليفة حتى أخذ بيد

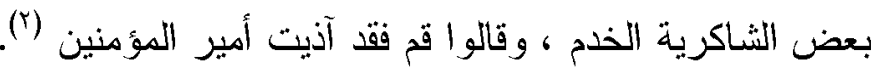
ولكن فى الواقع فإن لفظة الثاكرية بما تحملة من دلالة اصطلاحية ضاربة فى القدم، فرغم كل ما ظهز من اجتهادات حول توقيت بروز مصطلح الثاكرية، إلا أن الباحث وجد أن مصلح الثشاكرية

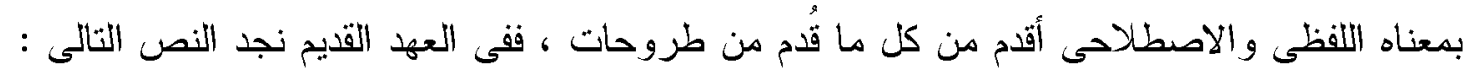

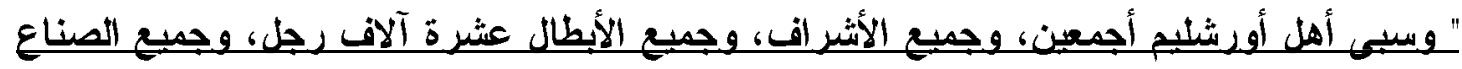

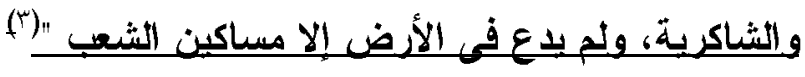
وفى الحقيقة فلم يكن الثاكرية ينتمون لأصل معين ولا إلى قيادة محددة ، ولكنهم انتموا إلى قيادات

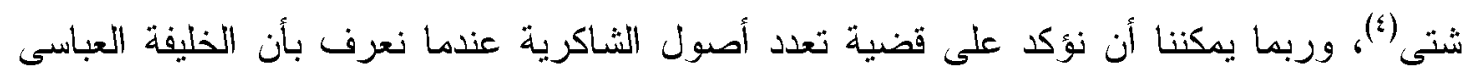

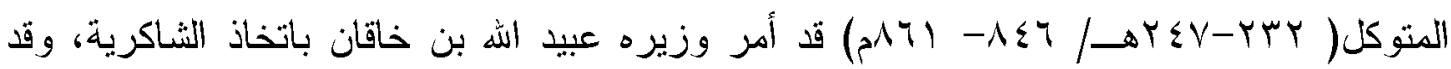
ضدت قوات الثناكرية الخاصة به اثنى عشر ألفاً من العرب والصعاليك وأهل الجزيرة و العراق

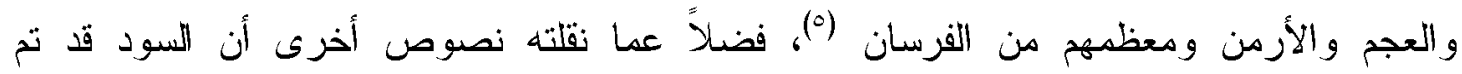

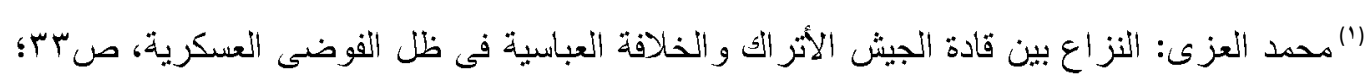
KHALIL , AL-SHAKIRIYYA, The Encylopadeia of Islam, ,p250.

(") أبى عبيد البكرى: سمط النلالى فى شرح أمال القالى، تحقيق: عبد العزيز الميمنى، دار الكتب العلمية،

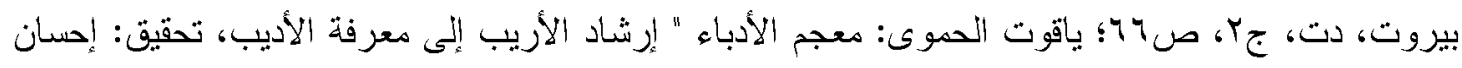

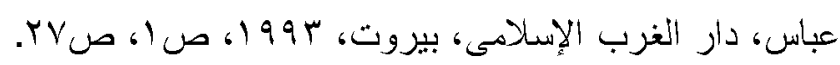

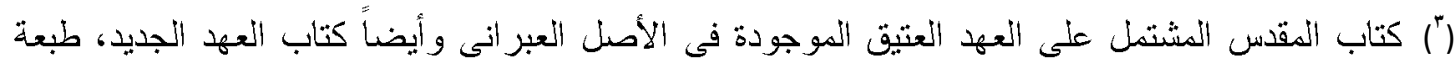

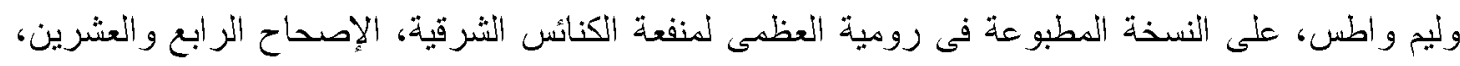

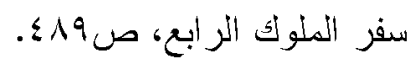

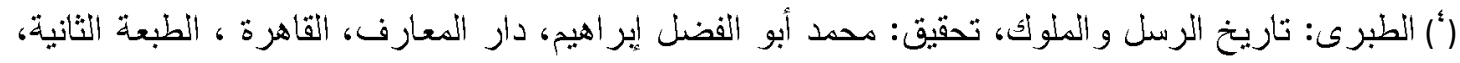

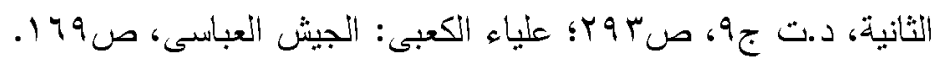

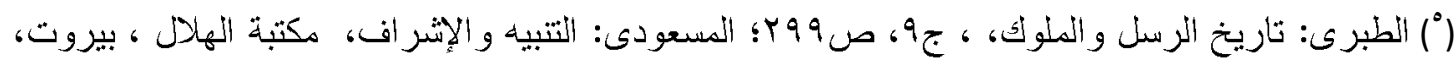

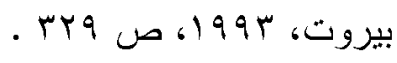


استخامهم كشاكرية فى بعض الأحيان نظراً لثجاعتهم وقوتهم (")، وما بساعدنا أيضاً على تعضيد

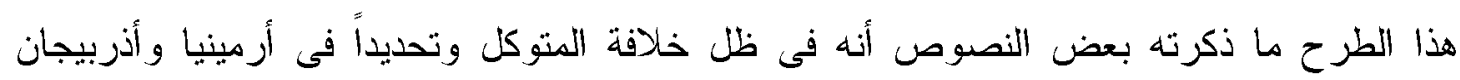

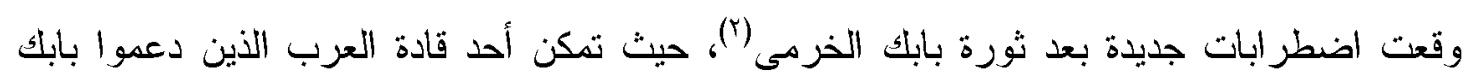

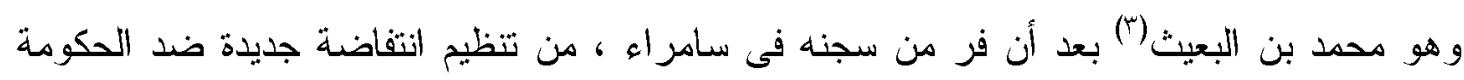

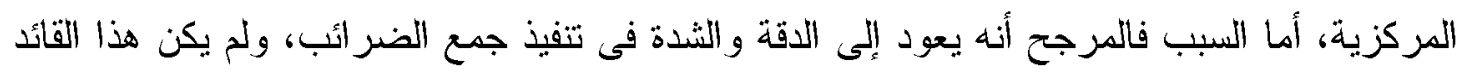
يحظى بدعم كبير، لذلك أُخدت الحركة بسرعة، ومن الطريف أن أبناءه تجندوا فى جيش الثاكرية

(') التتوخى: الفرج بعد الثدة، تحقيق: عبود الثثالجى، دار صادر، بيروت، 9 اج؛؛ ص، و9 1؛ فهمى عبد

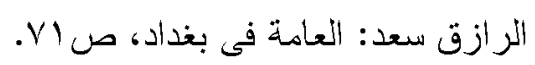

() تعد حركة بابك إحدى الحركات الفارسبة التي ظهرت في العصر العباسي الأول ، وترجع أصول هذه

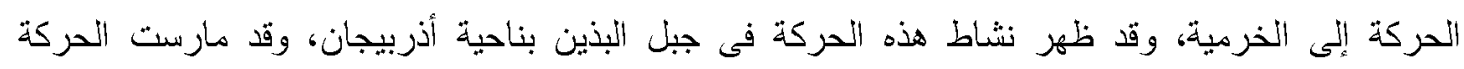

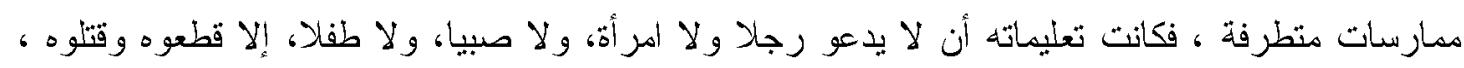

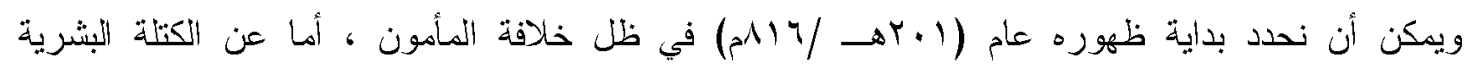

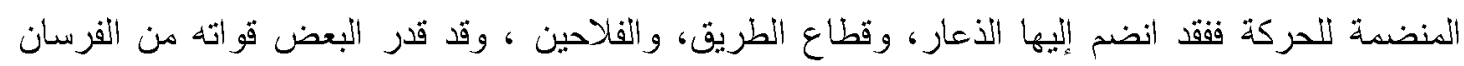

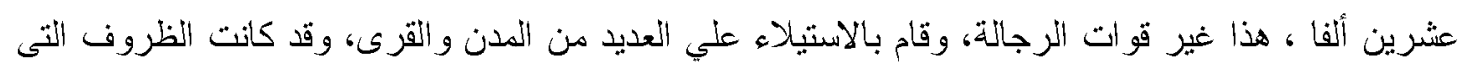

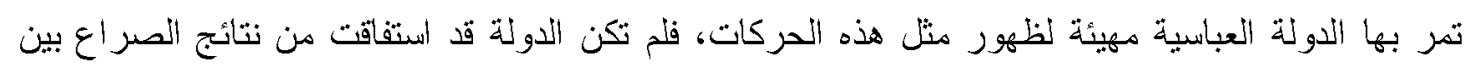

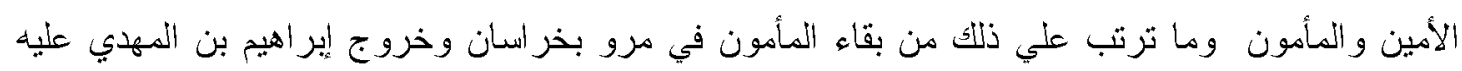

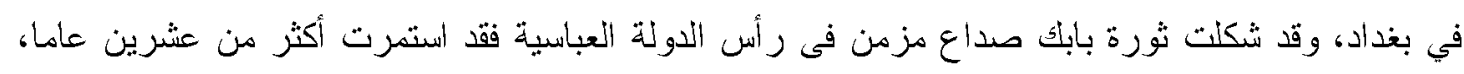

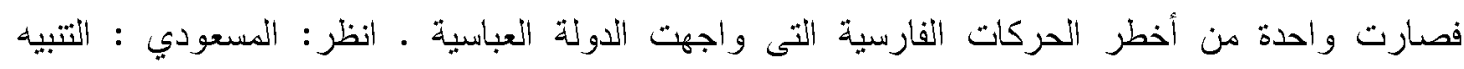

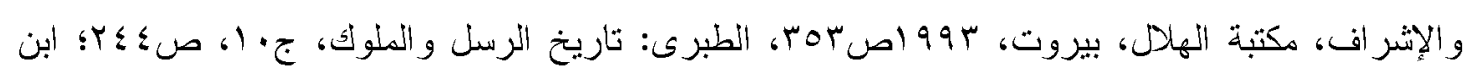

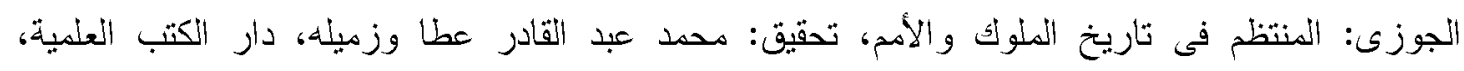

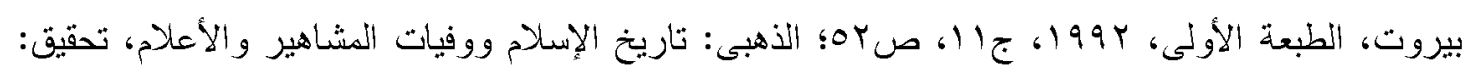

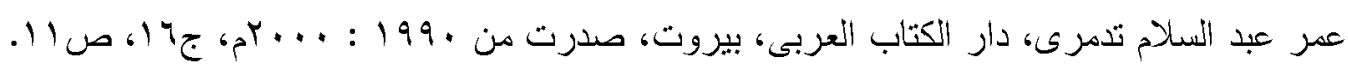

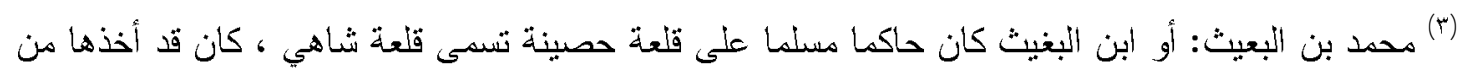

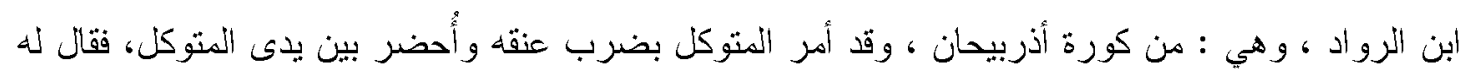

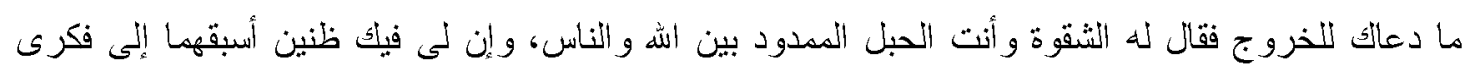

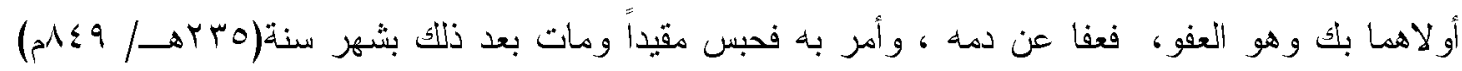

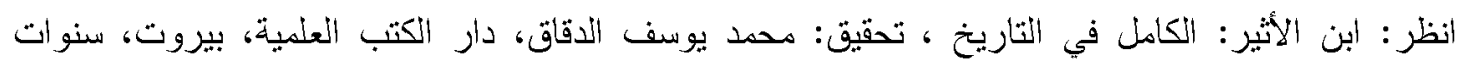

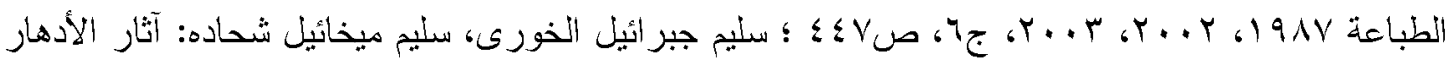

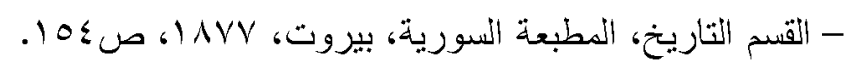


مع عبيد الله بن يحيى بن خاقان إلى جانب بعض أبناء بلادهم (')، وربما توضح لنا هذه النقطة ملمحاً

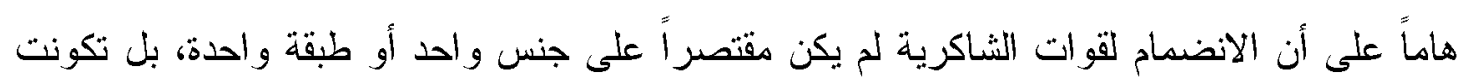

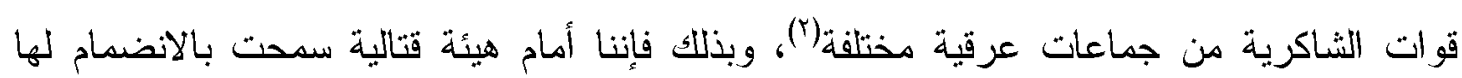
بكل مرن حسب مقتضيات كل مرحلة .

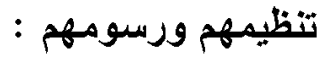

تميزت الثاكرية بوضعية مختلفة عن باقى الفرق العسكرية (")، فتصنيفها كقوات خاصة جعل لها

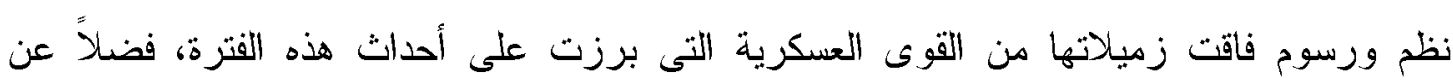

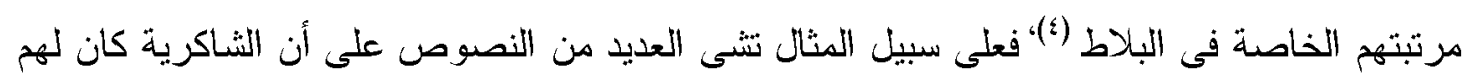
وضع مخصوص فى الأعطيات والمستحقات المالية فاقت كافة العناصر الأخرى (o) ، فنجد مثلخً أنه النه

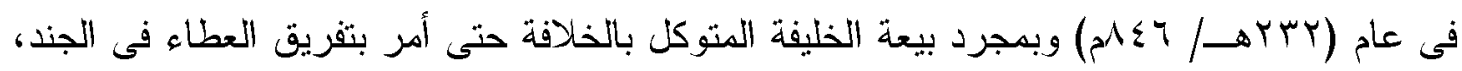
و الغريب أنه ميز الثاكرية عن باقى عناصر الجند، ففى حين أمر بعطاء أربعة شهور للمغاربة،

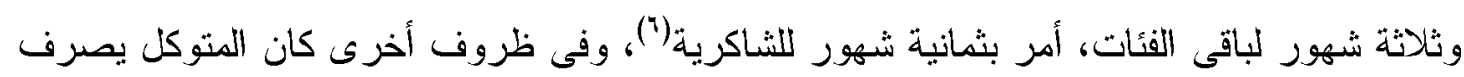

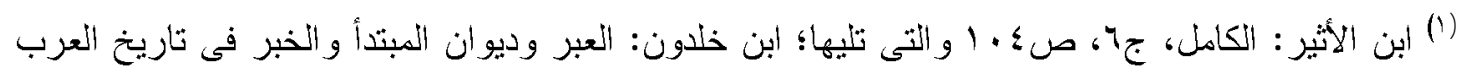

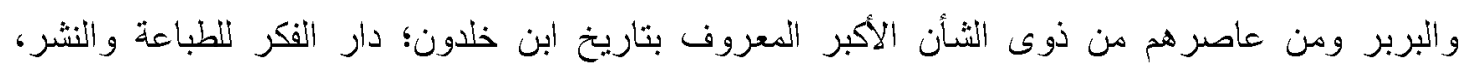

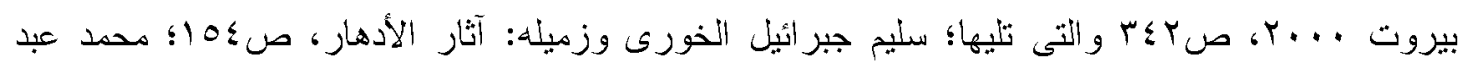

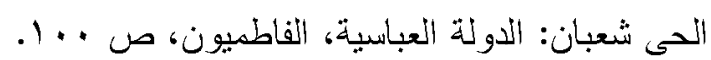
KHALIL, AL-SHAKIRIYYA, The Encylopadeia of Islam, ,p250.

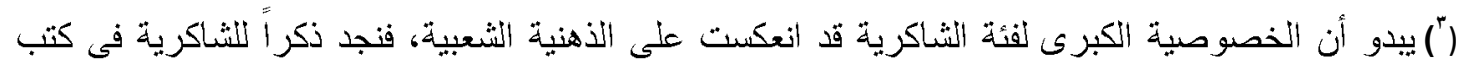

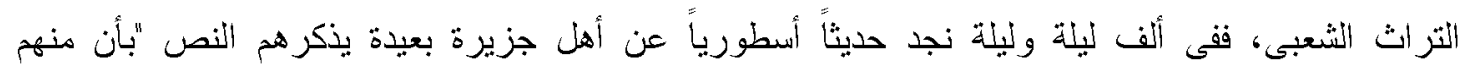

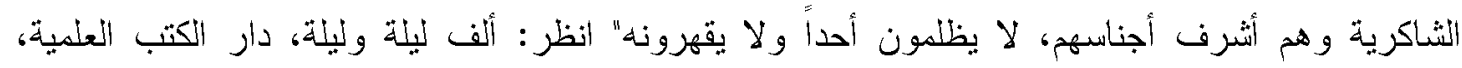

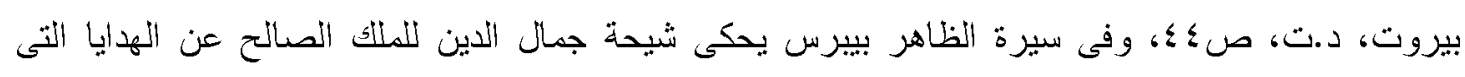

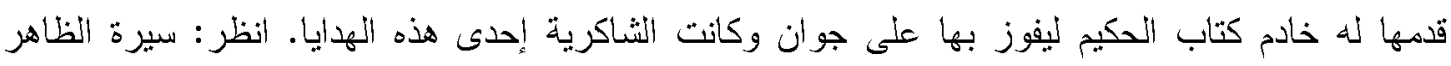

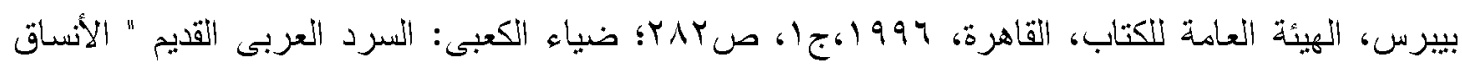

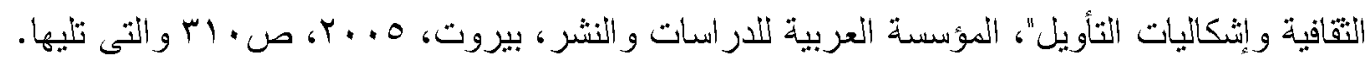

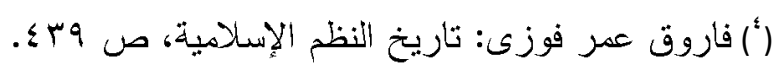
KHALIL , AL-SHAKIRIYYA, The Encylopadeia of Islam, ,p250.

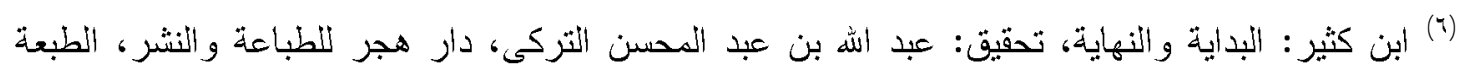

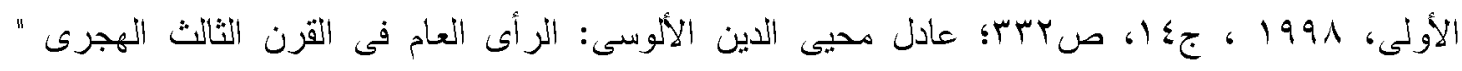


له مكافأة عشرة أشهر (') فى إجر اء له دلالة واضحة عن الوضعية الممبزة للثاكرية فى ذلك الوقت،

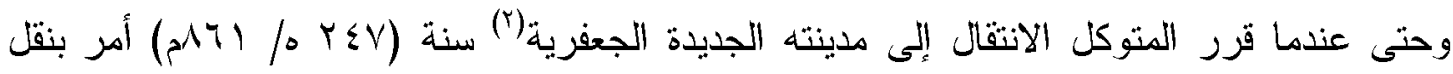
الدواوين معه وكان أبرز هذه الدو اوين التى أمر بنقلها ديوان الجند و الثاكرية (“) .

وارتباطاً بالطرح السابق فبعد أن بايع الأترالك الخليفة المعتز بالخلافة استهل عهده بمجموعة من القررات كان أبرزها صرف العطاء للثاكرية (؛)، وهو الأمر الذى يساعدنا على استقراء الوضعية الحقيقة لقوة الشاكرية آنذاك .

وفى واقع الأمر فقد كان التطور الكبير الذى لحق على الثاكرية هو انضمامه الرسمى للمؤسسة العسكرية بشكلها النظامى، ففى أواخر العصر العباسى الأول تم تسجيل الثـاكرية فى ديوان واحد مع الجند سمى ديوان الجند والشاكرية"() بعد أن كانوا مجرد قوات غير نظامبة (') وحسبما

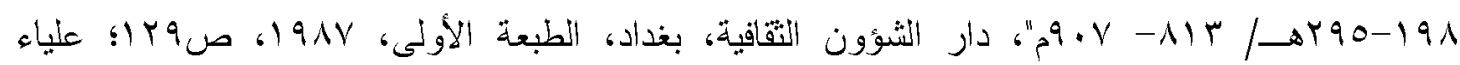

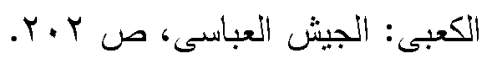

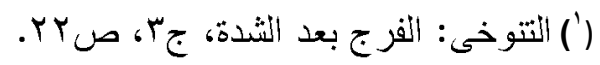
(') نسبث إلى القصر الذى بناه الخليفة المتوكل قرب سامر اء بموضع بسمى الماحوزة، فاستحدثت عنده مدينه

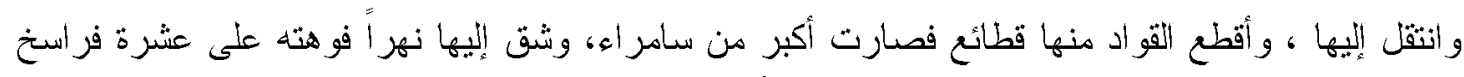

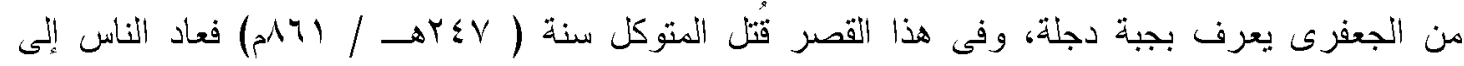

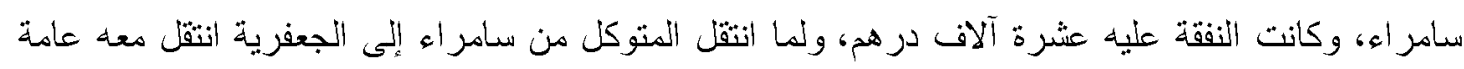

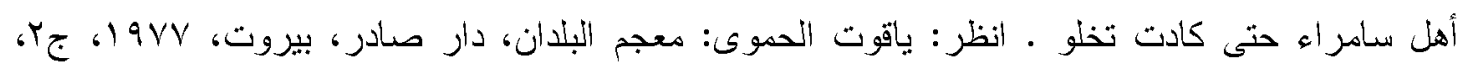
صن

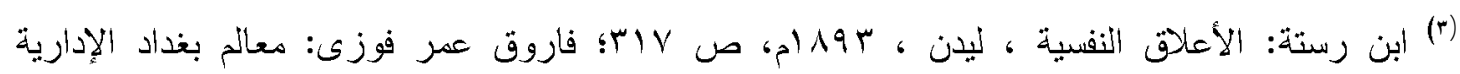

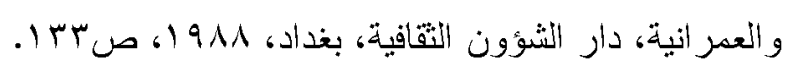

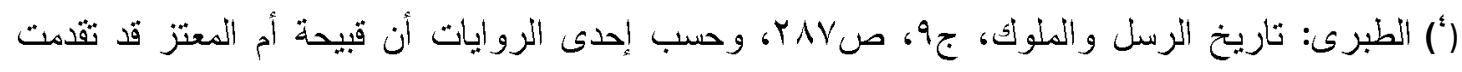

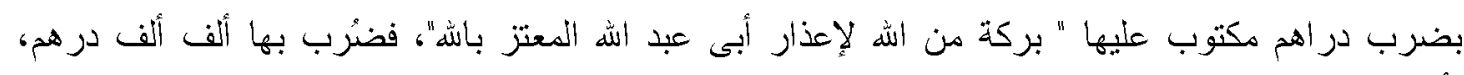

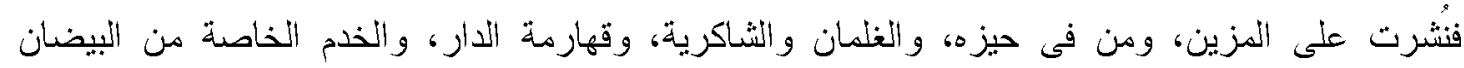

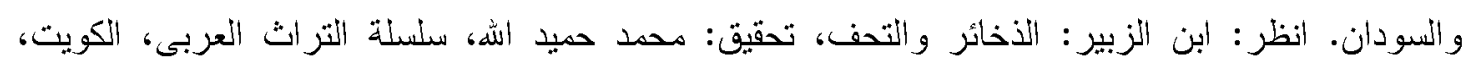

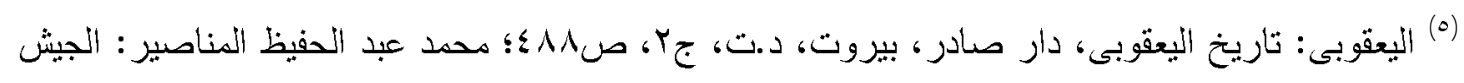

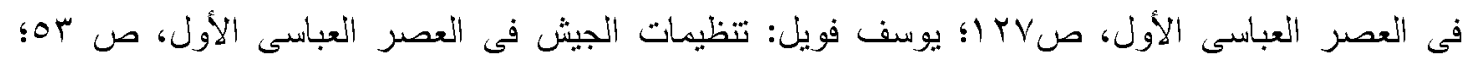

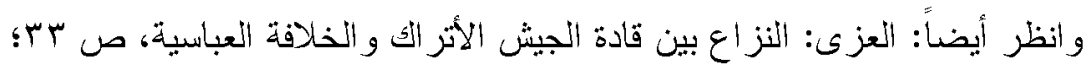
KHALIL , AL-SHAKIRIYYA, The Encylopadeia of Islam, ,p250. 
فسر أحد الباحثين أن فى تسمية الديوان بهذا الاسم دلالة واضحة على كثرة عددهم أو دورهم الهام

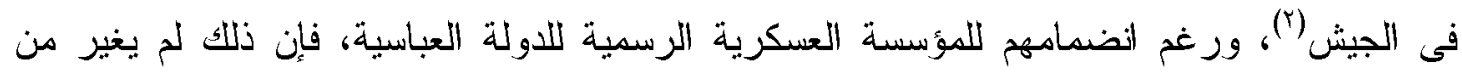

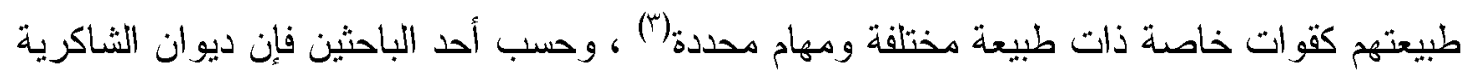

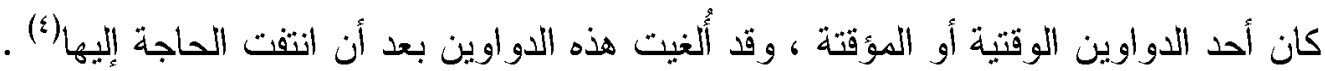
كما يُفهز من خلال نصوص عدة أن النشاكرية كانت لهم دواب معروفة ومميزة للجميع (م)، فكانت تكسى ديباجاً ببراقع (") ، وكانت توسم أسماء من يقوم الثاكرية بحر استهخ من أمراء أو كبار رجال

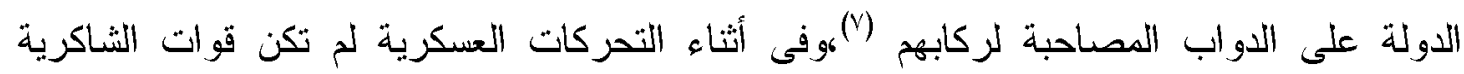

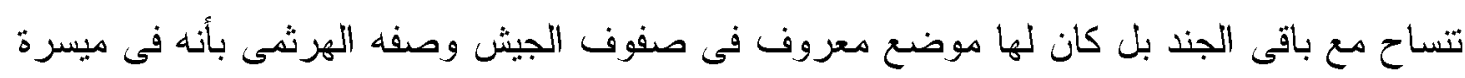

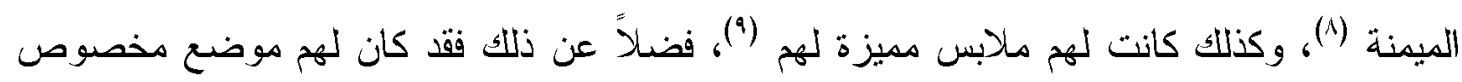

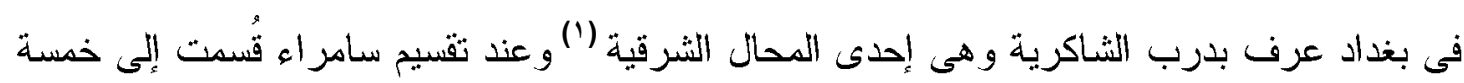

(1) علياء الجيلى: عناصر الجيش العباسى وآثارها العباسية على الخلافة العباسية، بحث منشور بمجلة كلية

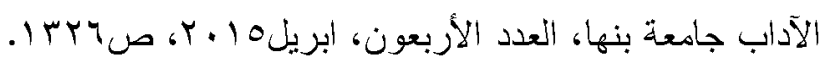

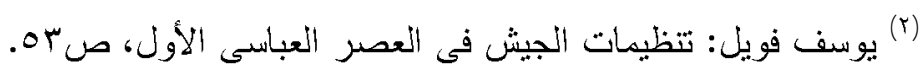
KHALIL, AL-SHAKIRIYYA, The Encylopadeia of Islam, ,p250.

(أ) فاروق عمر فوزى: تاريخ النظم الإسلامية دراسة لتطور المؤسسات المركزية فى الدولة فى القرون

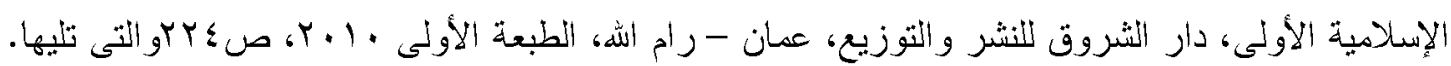

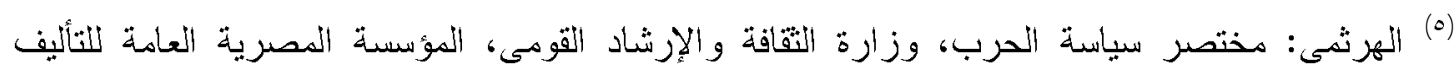

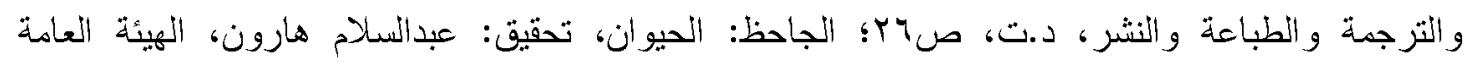

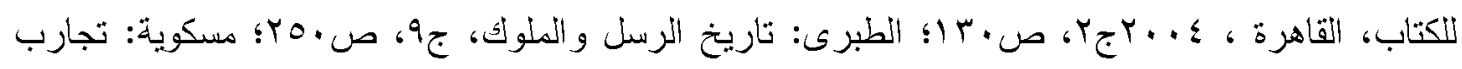

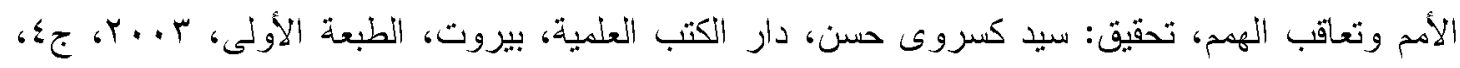

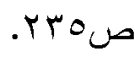

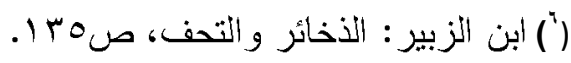

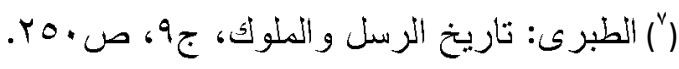

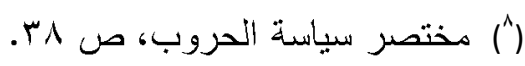

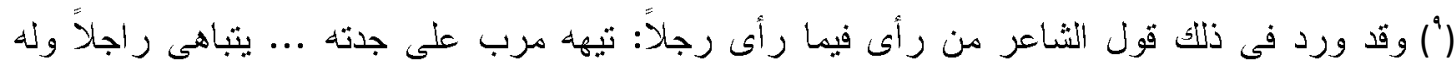

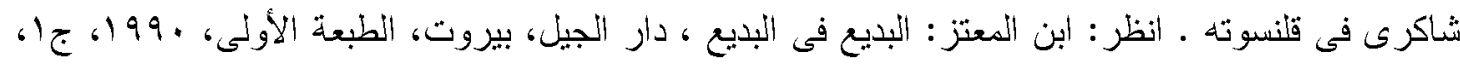


خمسة شوارع رئيسية، كان أحدها مخصوصاً للشاكرية، فى الشارع الثالث وهو شارع " الحير" الذى توجد فيه قطائع الجند و الثاكرية(r).

\section{دور الثاكرية فى التثريفات والحر اسات الخاصة :}

ارتبط ظهور الثاكرية فى التاريخ العباسى بالوجاهة الثخصية فى المواكب والحاثية، فعلى سبيل المثال تذكر بعض النصوص أن أم جعفر بنت جعفر المنصور أول من اتخذت الشاكرية من الخدم يركبون الدواب ويختلفون فى قضاء حوائجها برسائلها وكتبها(")، فضدًا عن ذلك فقد كانت الحر اسات الثخصية أحد أبرز الأدوار التى قام بها الثاكرية (๕)، فقد اتخذ الخليفة المهدى(0/1-991هـ|

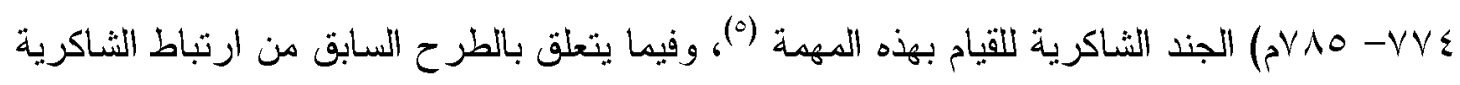

(1) وهى ناحية فى الجانب الثشرفى من بغداد من نهر المعلى انظر: التتوخى: الفرج بعد الثدة، تحقيق: عبود

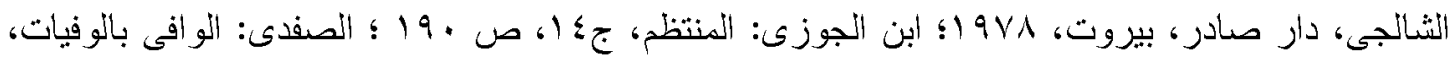

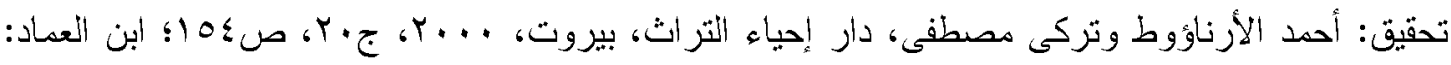

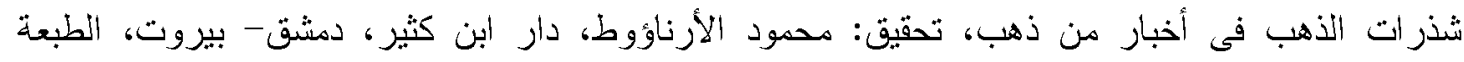

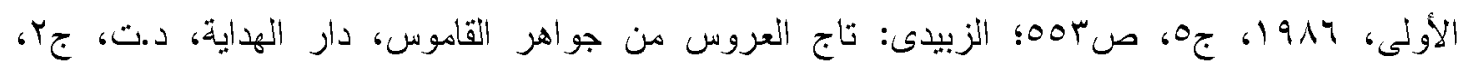

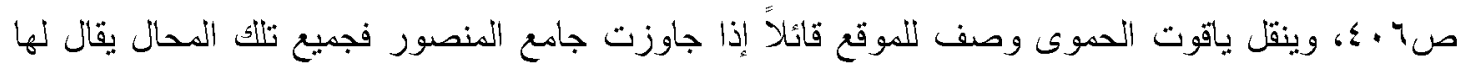

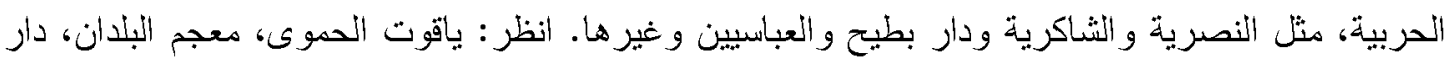

$$
\text { صدادر، بيروت، (19VV) }
$$

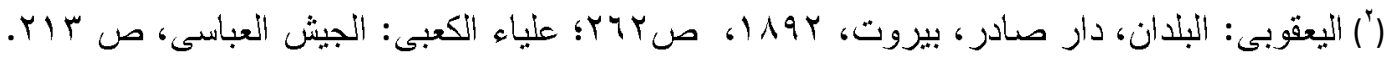

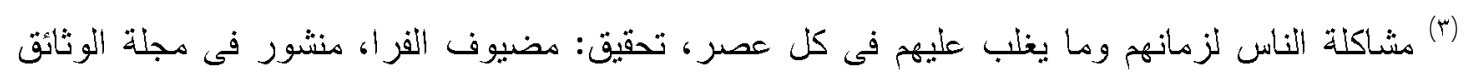

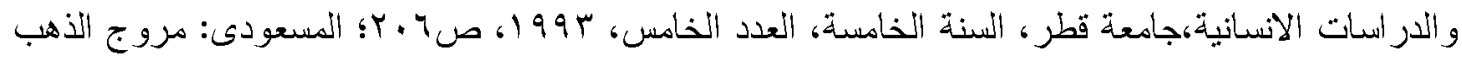
ومعادن الجوهر، تحقيق: محمد محيب الدين عبدالحميد، مكتبة الرياض الحديثة، الرياض، الطبعة الخامسة،

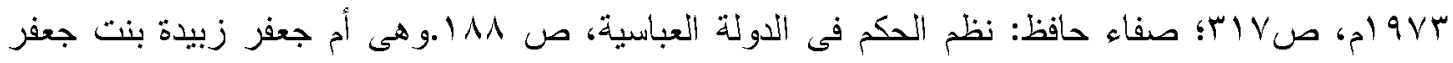
بن أبى جعفر المنصور ، اسمها أما العزيز، ولقبها جدها أبو جعفر المنصور زبيدة، لبضاضتها ونضدارتها،

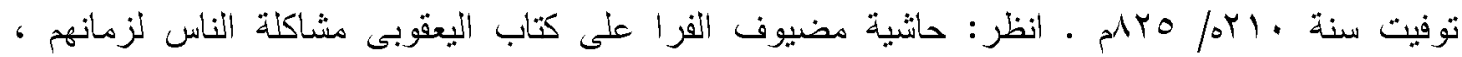




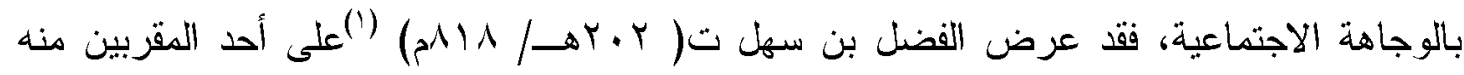

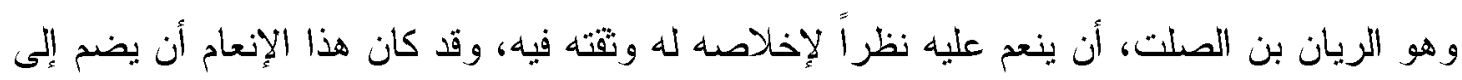

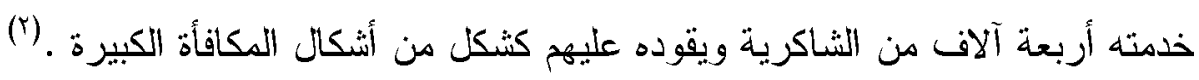
وفى واقع الأمر فقد تم توظيف عناصر الثاكرية من قبل معظم الأمزاء المحليين كحراس

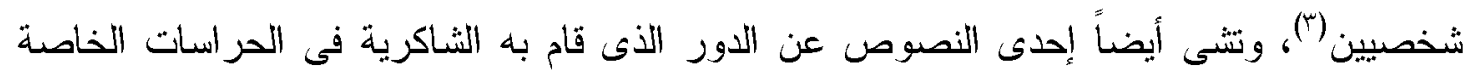

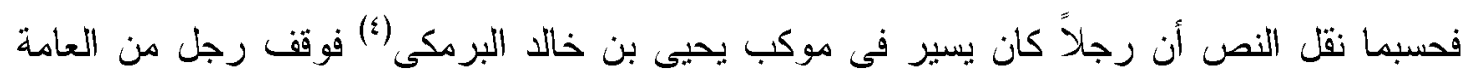

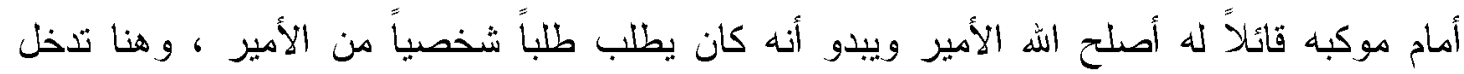

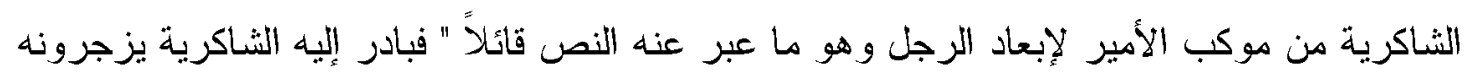
من حو اشى موكبه". (0) من موكب الامين

هذا وقد كانت التثريفات أحد أبرز الأدوار التى قامت بها الثاكرية، فقد أمر الخليفة المتوكل

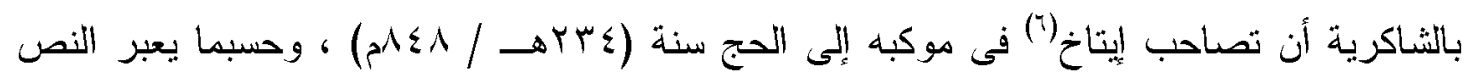
(') الفضل بن سهل السرخسي الوزير أخو الوزير الحسن بن سهل، أسلم أبوهما على بد الكهدي وأسلم الفضل

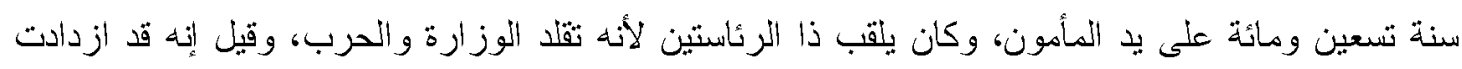

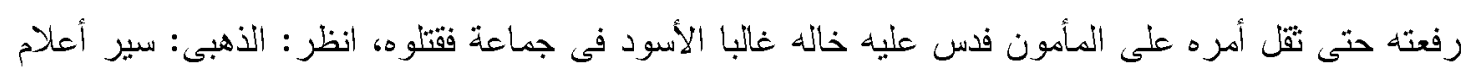

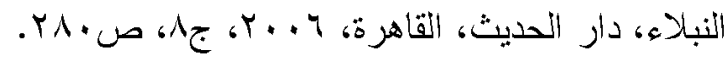

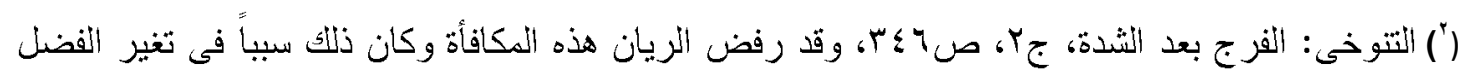

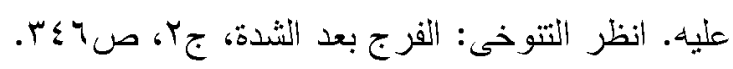
KHALIL, AL-SHAKIRIYYA, The Encylopadeia of Islam, ,p250.

(if يحيى بن خالد بن برمك أبو علي الوزير و اللا جعفر البرمكي، ضم إليد المهدي ولده الرشيد فرباه،

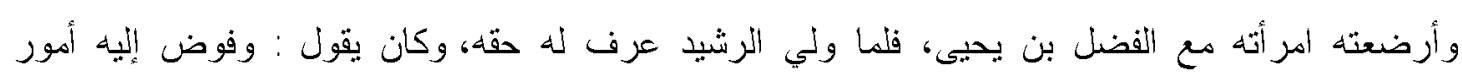

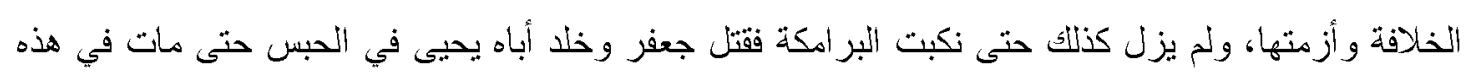

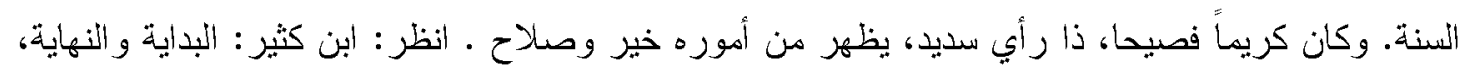

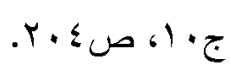
(0) البيهقى: المحاسن والمساوقه، تحقيق : محمد أبو الفضل إبر اهيم، دار المعارف، القاهرة، ابلام جاه ص 9 ص 9

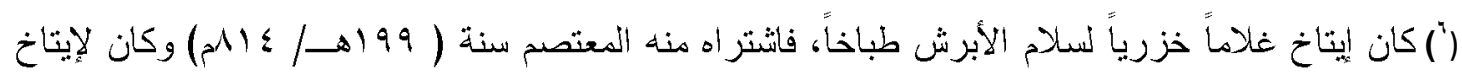

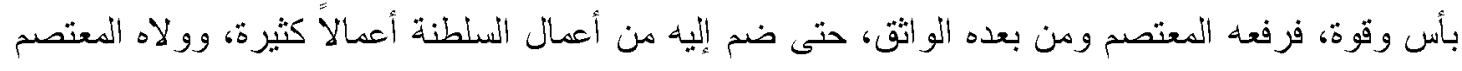

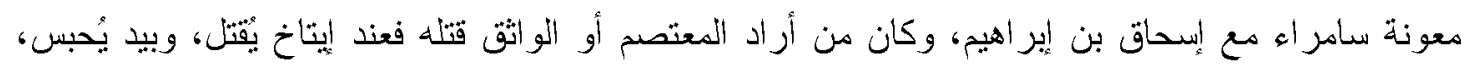


أنه " خلع عليه، وركب جميع القو اد معه ، وخرج معه من الثاكرية و القو اد و الغلمان سوى غلمانه وحشمه بشر كثير" (')، ومن المثير اللسخرية أن الشاكرية الذين تم استخدامه كحراس وحاشية لإيتاخ، نجدهم حاضرين بعد ذلك فى مشهد القبض عليه تمهيداً لقتله فى سنة( هبrهـ / حيث صدرت الأو امر لو الى بغداد بشحن الجسر بالجند و الثاكرية (').

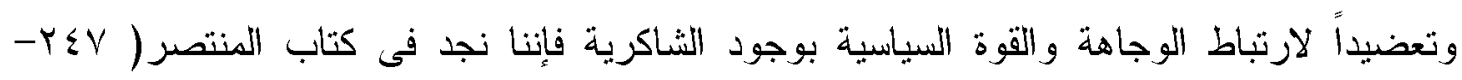

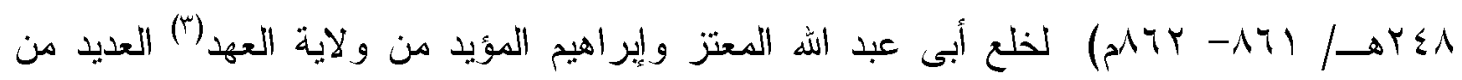
الثروط ، كان أبرزها تخليهم عن شاكريتهم، فاشترط عليهم قائلاً " وأن يخرج من كان ضُم إليهما ممن فى نواحيها من قو اد أمير المؤمنين، ومو اليه، و غلمانه، وجنده، وشاكريته ...، وأن بزال عنه

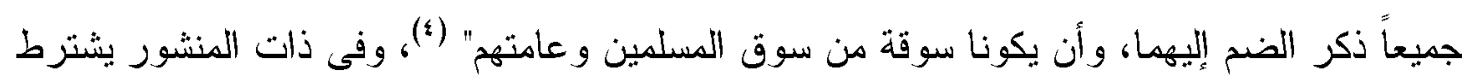
عليهما شرط آخر وهو " أن يزيلوا ما على الأعلام والمطارد من ذكرهما، وما وُسمت به دواب الثاكرية و الر ابطة من أسمائهما"(0).

منهم محمد بن عبد الملك الزيات، فلما ولى المتوكل، كان إيتاخ فى مرتبته، إلبه الجيش والمغاربة والأتر الك

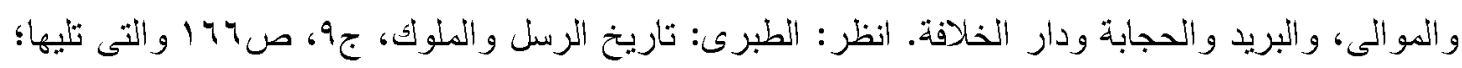

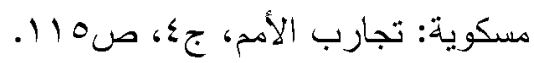

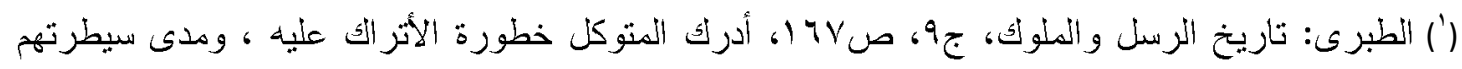

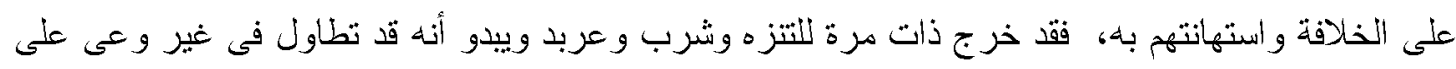

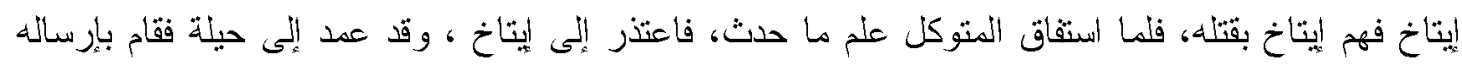

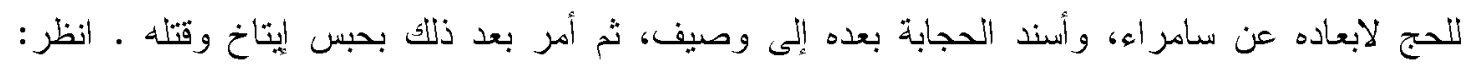

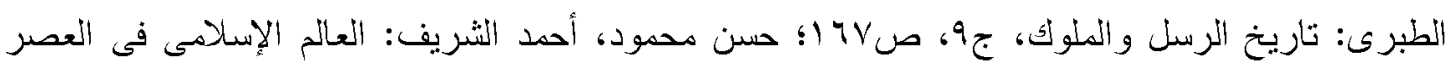

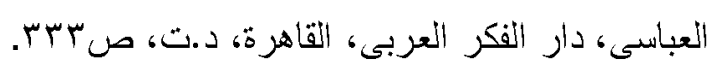

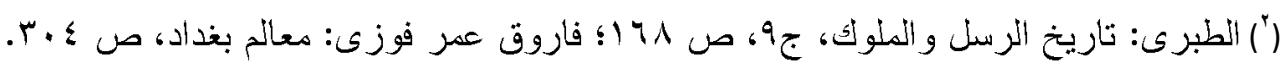

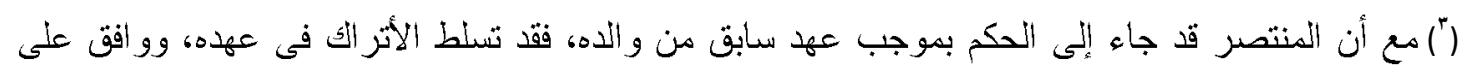

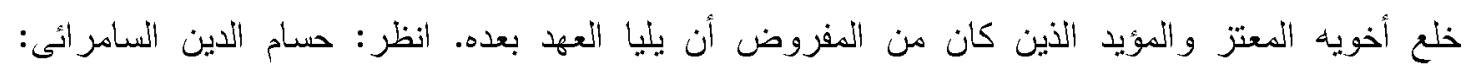

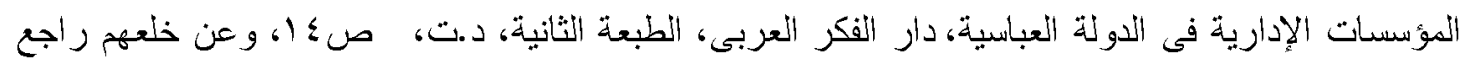

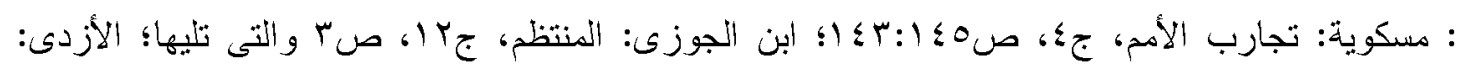

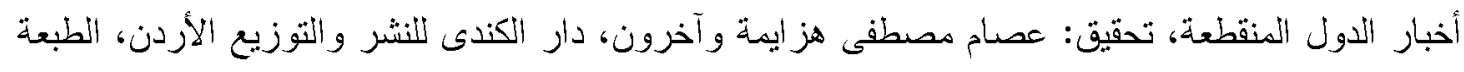

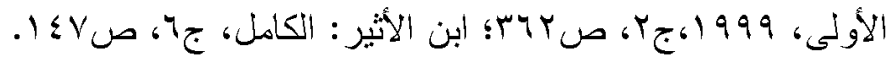

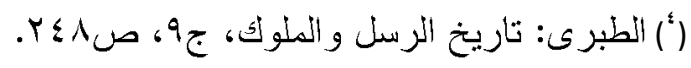

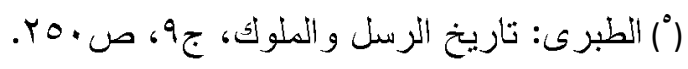




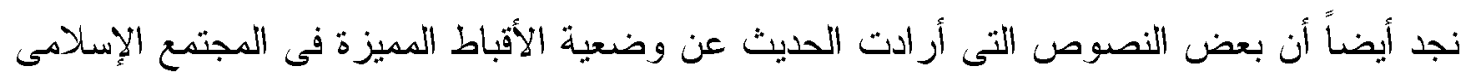

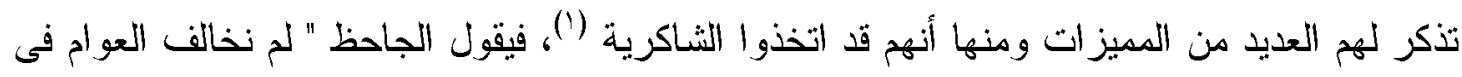

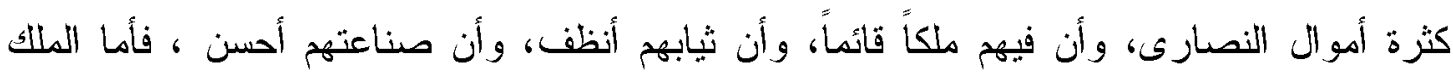

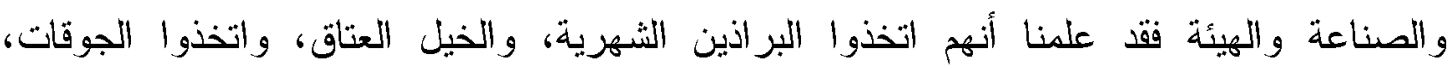

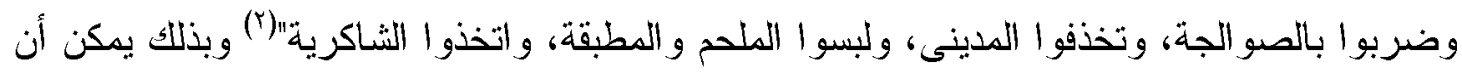

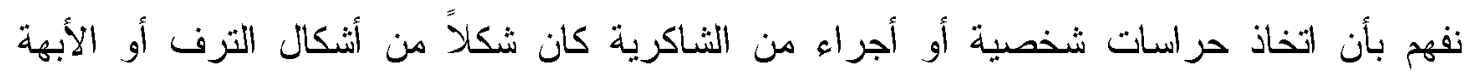

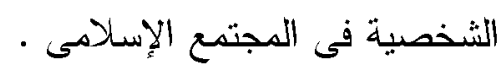

كما نطالع أيضاً فى سياق إحدى النصوص أن وصيفاً (") كان يستخدم الثاكرية فى الحر اسة الخاصة،

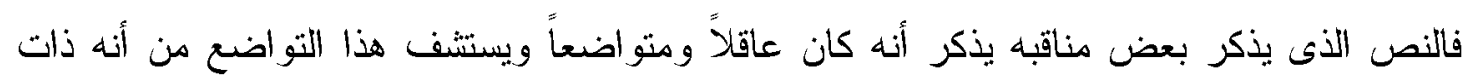

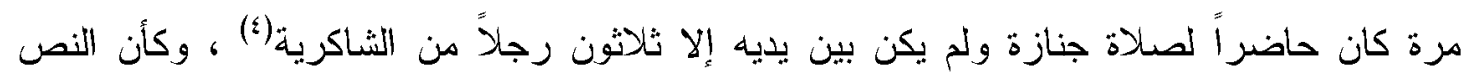
بستقل هذا العدد البسيط ، وما بعنيا هو أنه كان بعتمد على الشاكرية فى حراسته الثخصبة أثناء

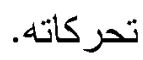

\section{الثاكرية ودور هم فى المهمات الخاصة :}

نستطيع أن نصنف قوات الشاكرية كقوات خاصة(0) ، أو كقو ات للتنل السريع اعتمدت عليها العديد من القوى فى الدولة العباسية لتتفيذ مهمات طارئة ذات طبيعة خاصة ، وليس معنى هذا أن كل

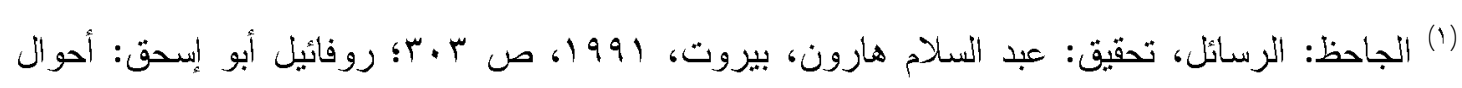

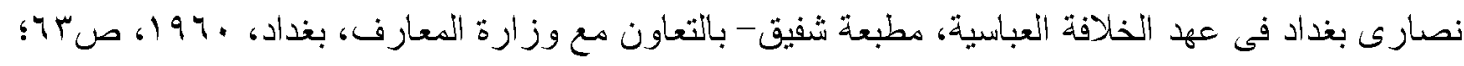

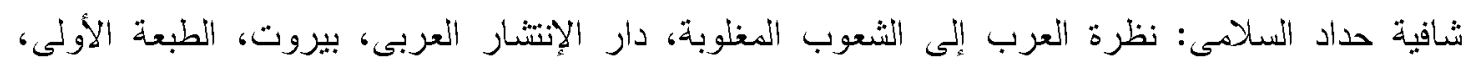

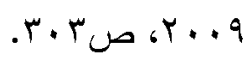

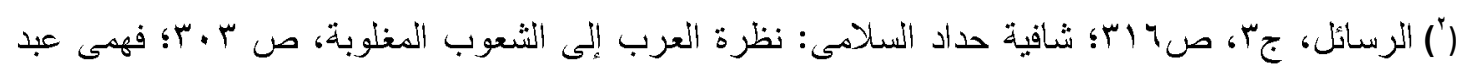

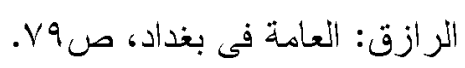

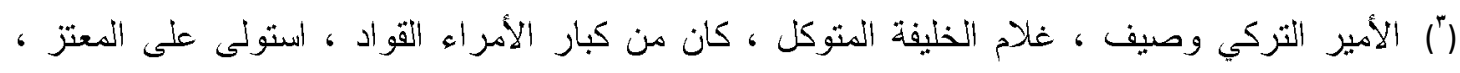

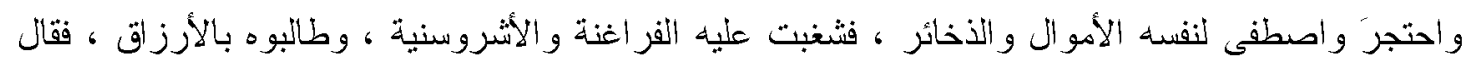

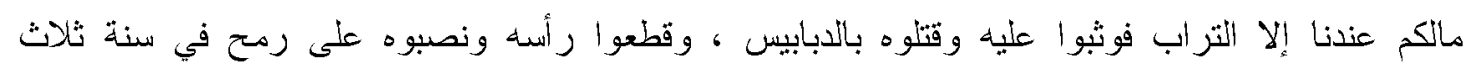

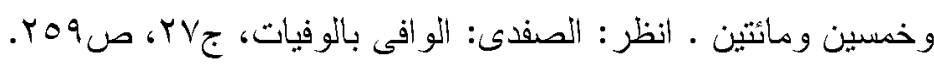

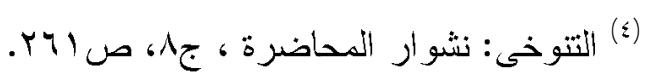

KHALIL, AL-SHAKIRIYYA, The Encylopadeia of Islam, ,p250. 
تدخلاته كانت ناجحة بطبيعة الحال، ولكنه رغم ذلك ظلوا محافظين على تصنيفهز كقوات مميزة

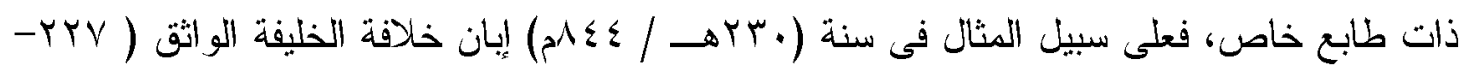

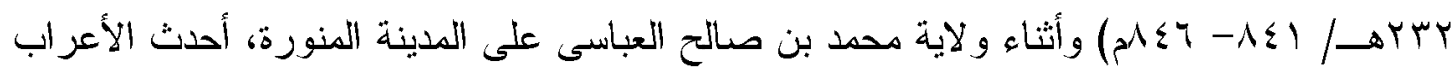
اضطر ابات وتهيدات حول المدينة المنورة الأمر الذى شكل تهديداً أمنياً على المنطقة، وبناءً عليه

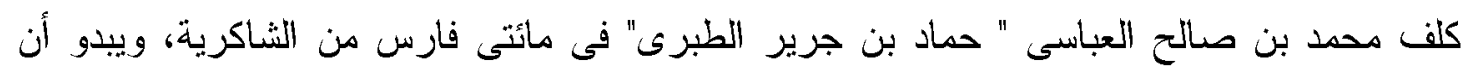
عدد الأعراب وتجهيزاتهم كانت تفوق قوات الثاكرية، الأمر الذى ترنب عليه قتل حماد وهزيمة

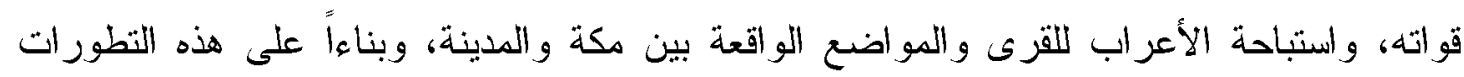

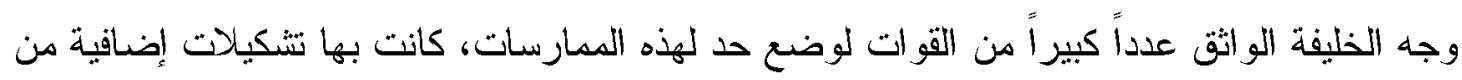

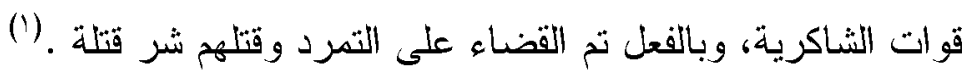

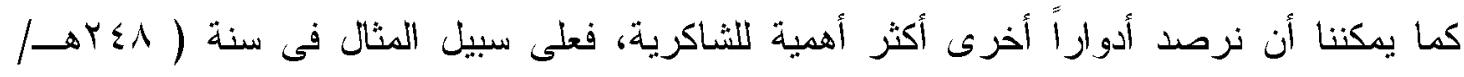

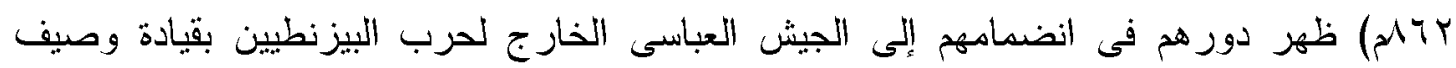

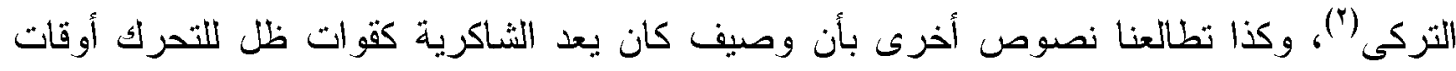

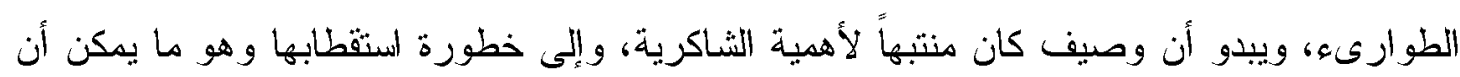

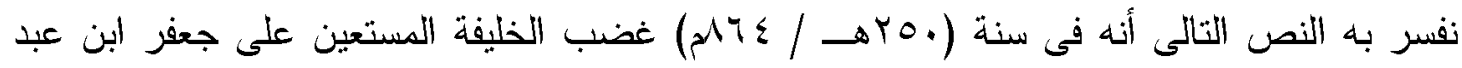

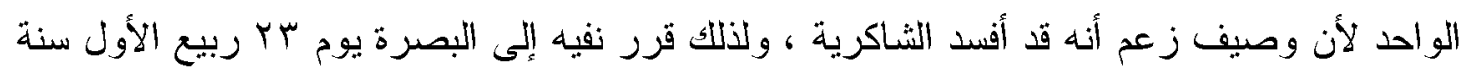

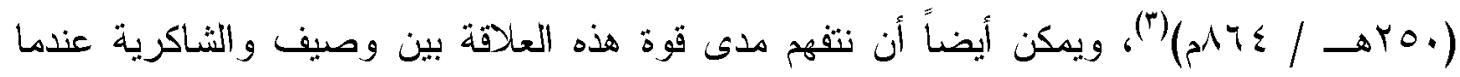

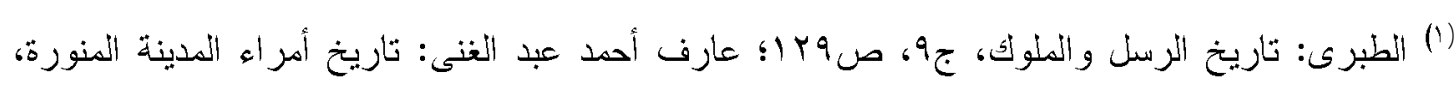

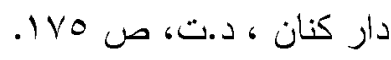

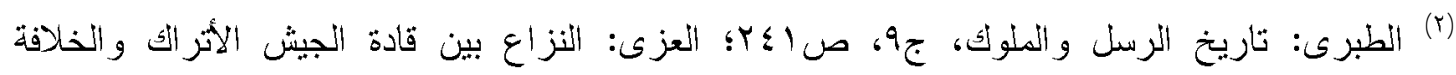

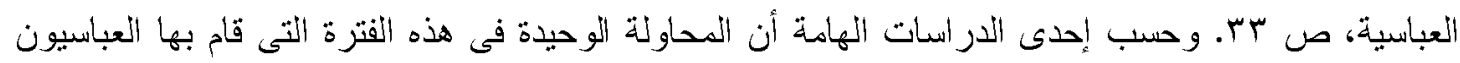

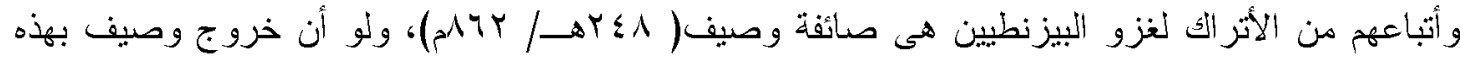

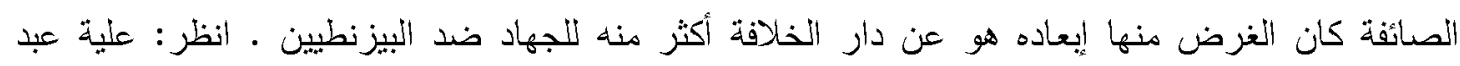

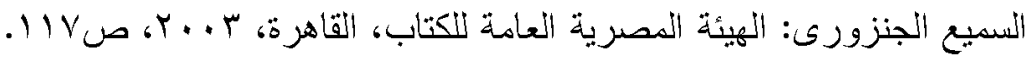

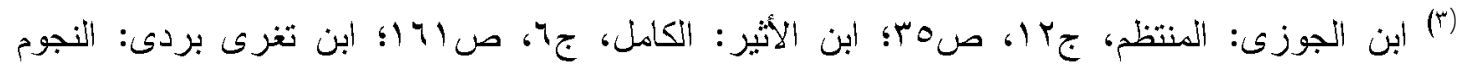

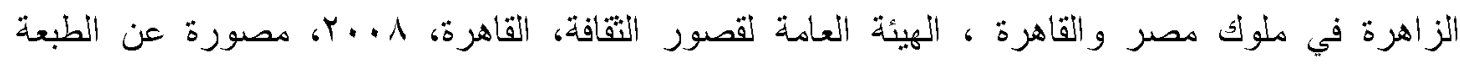

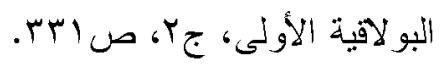




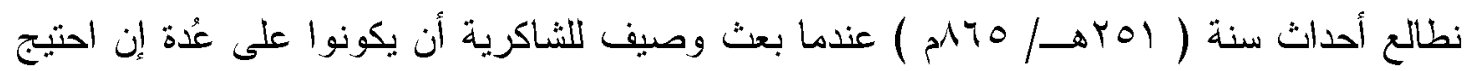

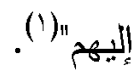

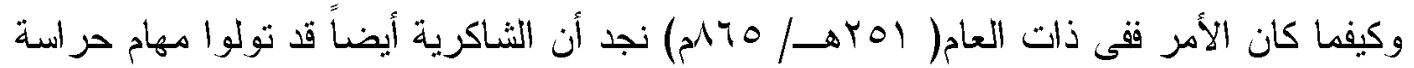

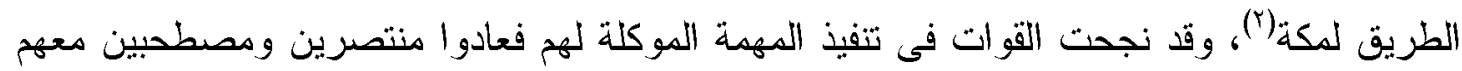

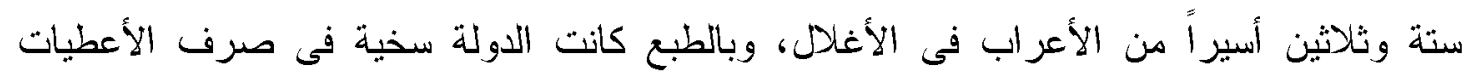

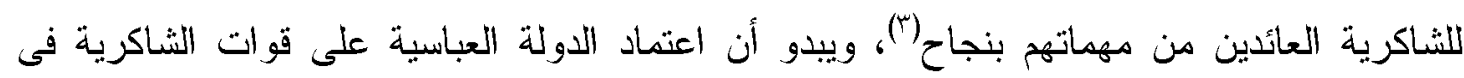

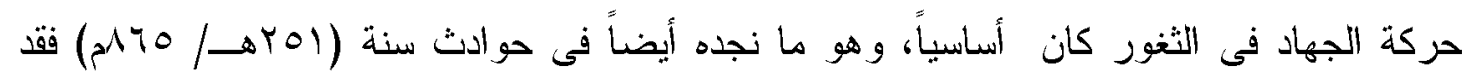

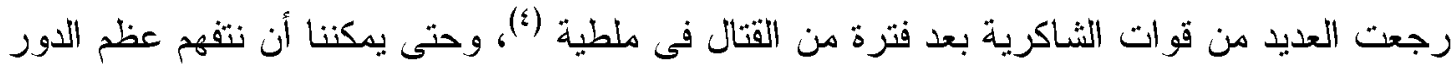
المنوط بهذه القوات فقى ذات العام نجد بعض الاضطرابات قد حدث فى الأنبار ، فكلفت السلطة

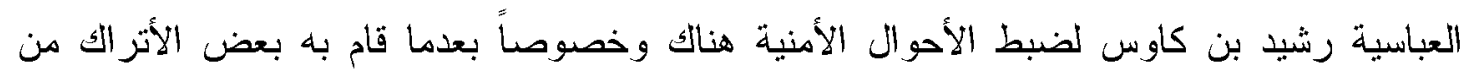

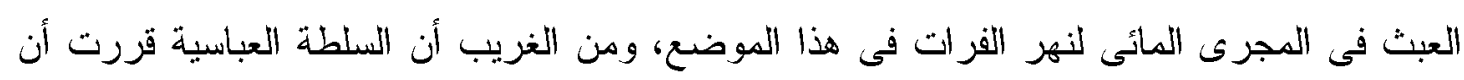
تحرك قوات الثاكرية التى عادت لتوها من ملطية، مما جعل الثاكرية يفرضون شروطهم ، ويبدو من وصف النص أنها كانت قوات ضخمة، فحسبما وصفه النص" فامتنع من كان قدم من ملطية من

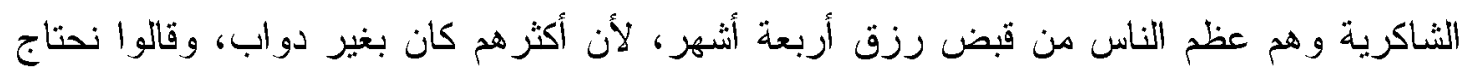

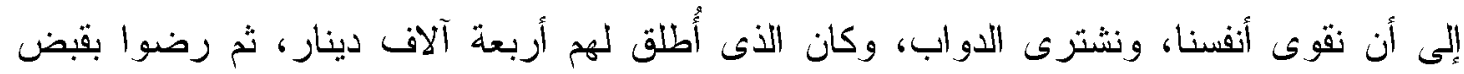

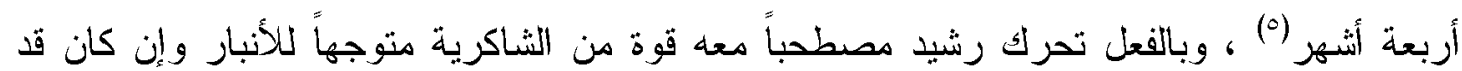

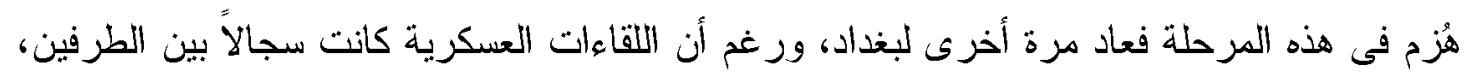

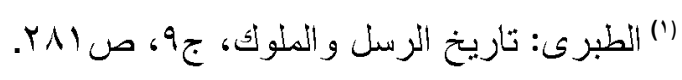

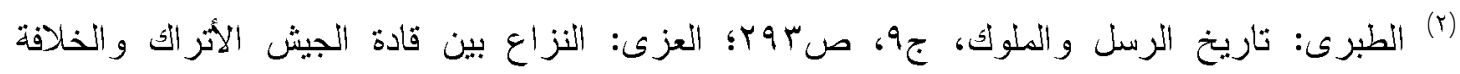

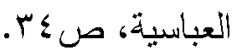

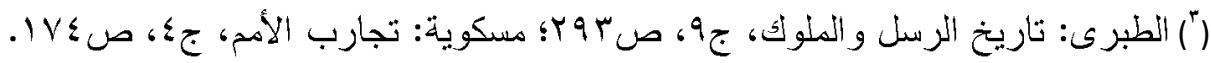

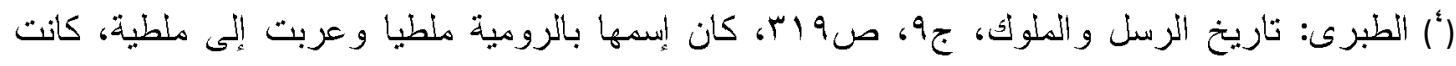

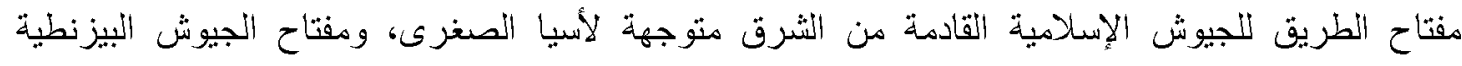

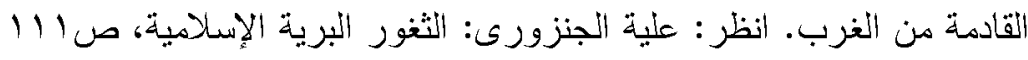

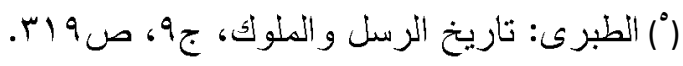


إلا أن ما بعنينا هنا أن كل الإمدادات التى أخرجتها السلطة العباسية لم تكن تخلو من وجود قوات للثاكرية فيها (1)

\section{بروز الثاكرية على المسرح السياسى فى الثرن الثالث الثهرى :}

بدأ الثاكرية خلال أحداث القرن الثالث الهجرى فى البروز على المشهد السياسى بأدوار جديدة، فالفئة التى عملت كخدم أو كأفر اد فى الحاشية أو فى أعظم الظروف كحراس شخصيين أو كقوات للتنخل السريع ، بدعوا فى تقديم أنفسه بشكل جديد، فصاروا فى كثير من الأحيان شركاء فى صناعة القرار، وصاروا طرفاً فاعلاً فى العديد من الصراعات السياسية التى شغلت أحداثها هذا القرن، وباستطلاع الخريطة السياسية للدولة العباسية آنذاك نستطيع أن نرصد أدوارًا عدة للشاكرية على جبهات متعددة، فستجد الثاكرية مشاركين فى حفظ الأمن فى مواضع الاضطر ابات كقوات للتخخل السريع، وللمر ابطة فى الثغور، و أخيرًا كمشاركين فى المعادلة السياسية الداخلية للدولة العباسية. إذن فقد أدركت السلطة العباسية أهمية الشاكرية كفرقة عسكرية قتالية، ويمكننا أن نتفه مدى خطورة قوة الثاكرية فى المعادلة السياسية عند مطالعة مرسوم الخليفة العباسى المتوكل بتولية العهذ لأبنائه الثلاثة عام ( هبrهـ/ العسكرية للشاكرية ونقتبس بعض ما جاء فى المرسوم على النحو التالى :

" وفى هذه السنة عقد المتوكل البيعة لبنيه الثلاثة لمحمد وسماه المنتصر، وولأبى عبد الله بن قبيحة ...ولقبه المعتز، ولإبر اهيم وسماد المؤيد بولاية العهد، ...و لا يُنقل عن واحد منهما أحدّ من ناحيته من القو اد و الجند والثاكرية و المو الى و الغلمان و غيرهم، ....وأن بطلق محمد المنتصر بالله لإبر اهيم المؤيد بالهد ابن أمير المؤمنين الخروج إلى الثام وأجنادها فيمن ضم أمير المؤمنين ويضمه إليه من مو البه وقو اده وخدمه وجنوده وشاكريته وصحابته وعماله وخدامه،...وأن عليه له فيمن ضم إليه من القو اد و المو اللى و الغلمان و الجنود والثناكرية ..."(r). وبذلك فقد كان الخليفة المنوكل يعتمد بشكل كبير على الشاكرية بل ويؤكد على أبنائه ضرورة الاعتماد عليهخ، وحسبما بعلق أحد الباحثين " أن مرامى المتوكل من بيعة أبنائه الثلاثة بولاية العهد

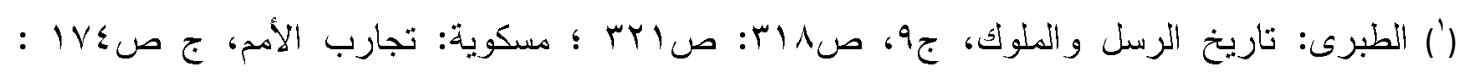

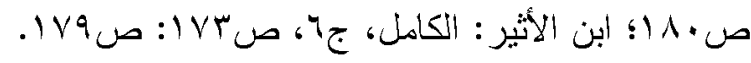

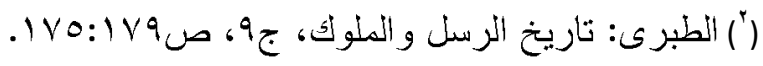


كان الغرض منها إضعاف قوة الجيش السياسية بتفتيث وحدته من جهة، واصطناع ولاءات جديدة له... وقد أكد المعتصم على إلحاق قسم من القواد و الجند و الثاكرية والمو الى والغلمان بكل ولى عهد فى حياته، وأكد المتوكل على ولى عهده الأول المنتصر عدم نقض هذا التقيم عند توليه الخلافة من بعده، مشدداً على عدم المساس بتبعية ما ألحق بأخويه وليى العهد من قوات عسكرية، وأن لا يُنقل عند واحد منهما أحدٌ من ناحيته من القو اد و الجند و الشاكرية والموالى و الغلمان، و ألزمه حال توليه الخلافة أن يُشخص أخاه المعتز إلى ولايته فى خراسان، ومعه جميع من ضم إليه أمير المؤمنين،

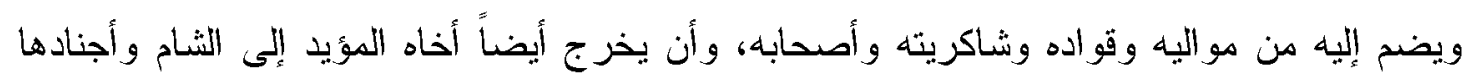
فيمن ضم أمير المؤمنين ويضمه إليه من مواليه وقو اده وخدمه وجنوده وشاكريته، وكان هدف المتوكل من هذه الإجراءات اصطناع ولاءات جديدة للجيش انحصرت بأولاده ولاة العهد (')، وضرب نفوذ قادة الجيش الأتراك(r)، وهو ما أكد عليه "المسعودي" أيضاًُعندا وصف لنا تدابير المتوكل بأنه " جفا الموالي" من الأتراك واطلَّرحه وحط مراتبهم وعمل على الاستبدال بهم و الاستظهار عليهج، وضم إلى وزيره عبداله بن يحيى بن خاقان نحواً من الثى عشر ألفاً من العرب ولهر و الصعاليك و غيرهم ...، وجعل يجبل الآر اء في استنصالهم"(") .

كذلك نجد فى عصر المتوكل أيضاً أن عبيد الهه بن خاقان (؛) قد اعتمد على الثاكرية لتشكيل قوة عسكرية خاصة (')، فقد كان يهدف لتجنيد جيش جديد وتتظيمه، وكان جميع أفراد هذا الجيش خاضعين مباشرة للمتوكل، على أن يكون و لاؤهم له فقط بصفته حاكماً لهم (r).

(') مضر عدنان طلفاح: بيعة الخليفة العباسى المتوكل على الله لأبنائه الثلاثة بولاية العهد فى عام| مبآهـا

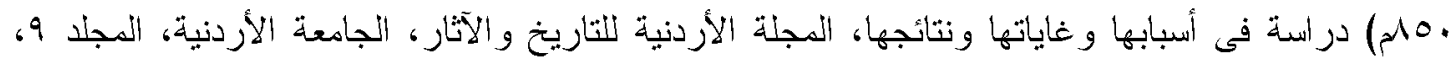

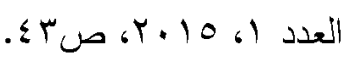

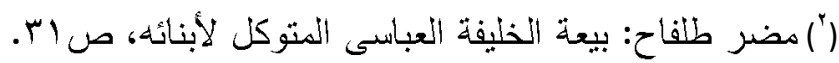

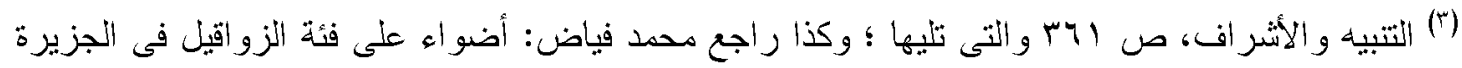

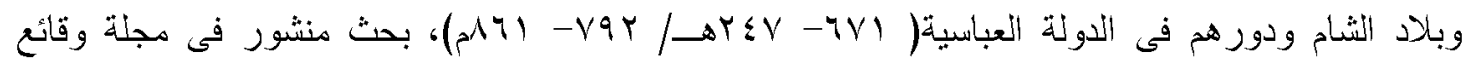

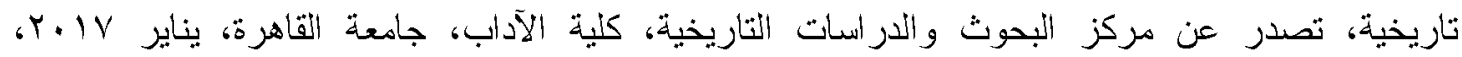
ص1.1. (") عبيد الله بن يحيى بن خاقان بن عرطوج أبو الحسن التزكي وزير المتوكل قدم مع المتوكل دمشق فيما

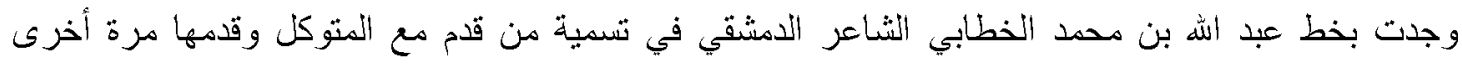

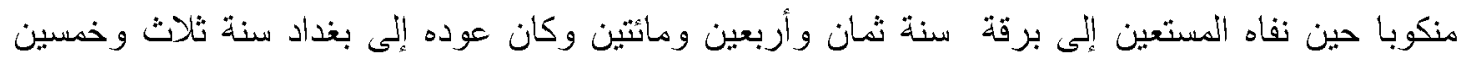

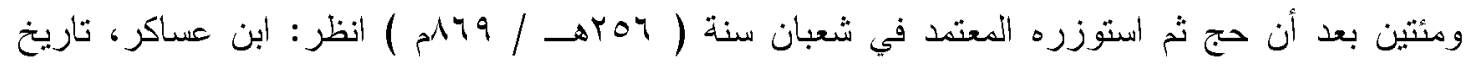

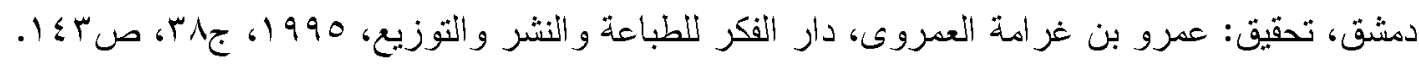


وحسبما عبر أحد الباحثين أنه لما بدا للمتوكل أنه السيد التام للسلطة أراد المتوكل أن يتخذ الخطوة الأخيرة للتأكد من نجاح سياساته نجاحاً تاماً، لكنها كانت الخطوة التى أدت إلى سقوطه، لقد ظن أنه النه يستطيع أن بدمج القوات السابقة فى سامزاء بجيش الثاكرية الجديد، ثم أدرك أن تحقيق هذه الغاية

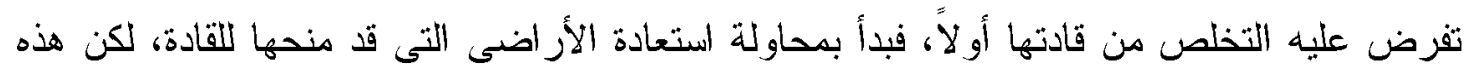
الخطوة كشفته، وبانكشاف نيته قزر هؤلاء القادة أن الوقت قد حان للتخلص منه قبل فوات الأوان، لأنه

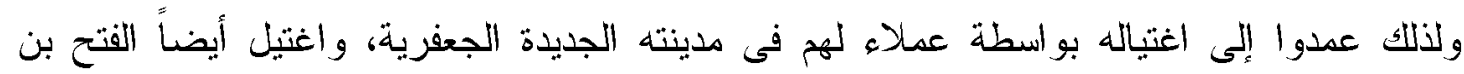

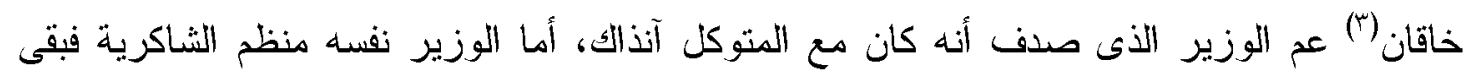

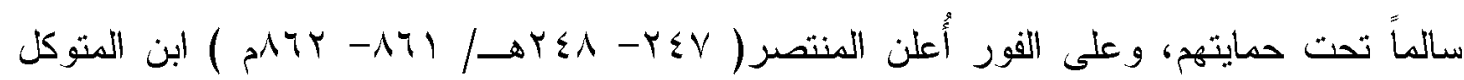

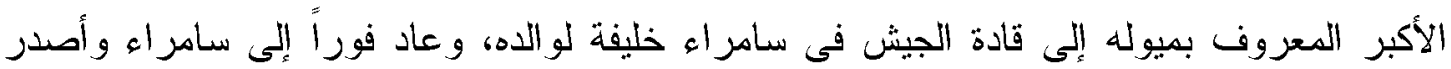

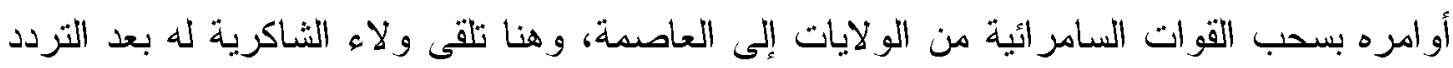

(₹). من ناحيتهم

هذا ويمكنا أن نلمح بعض التطورات الهامة فى الدور السياسى الذى لعبته الثناكرية آنذالك ، فقى سنة

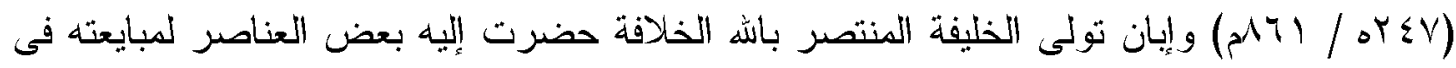

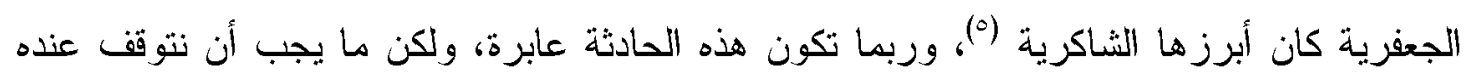

(') قام الخليفة العباسى الكتوكل أيضاً بالتعاون مع عبيد النه بن خاقان بالاعتماد على قوة الزوراقيل للتضاء على التى

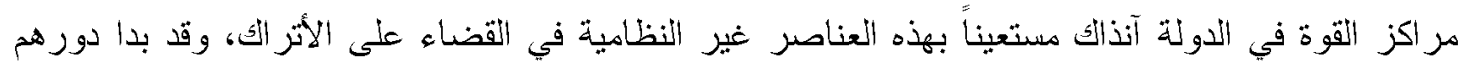

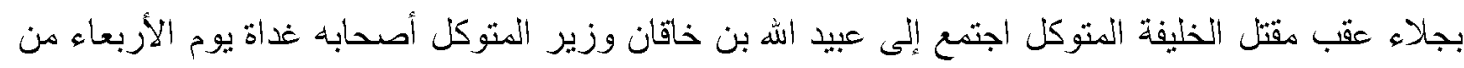

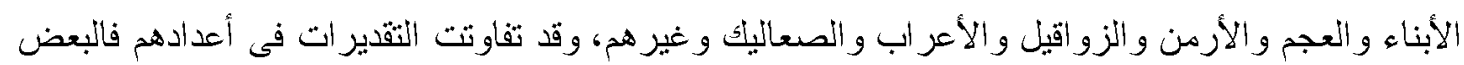

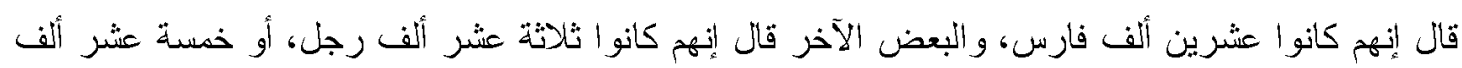

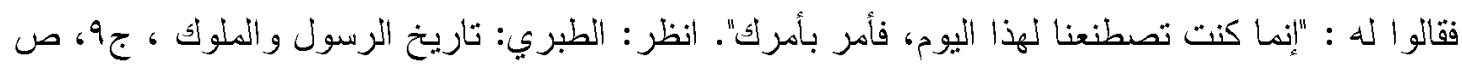

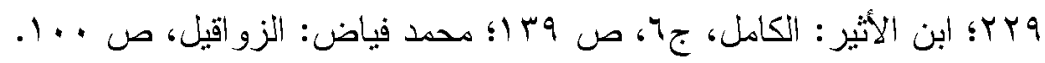

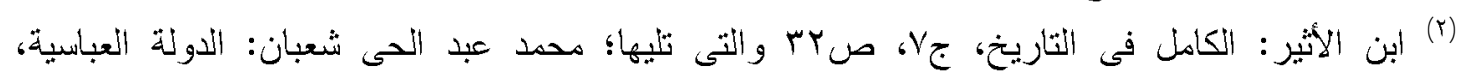

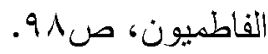

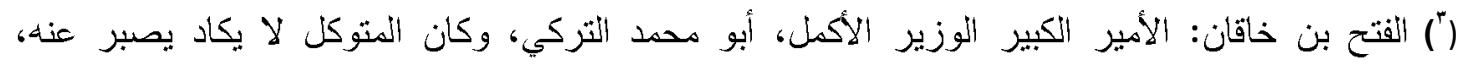

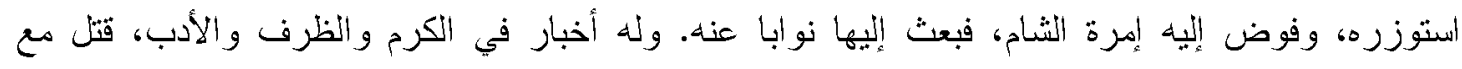

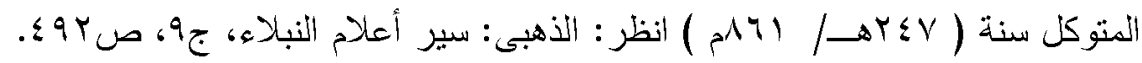

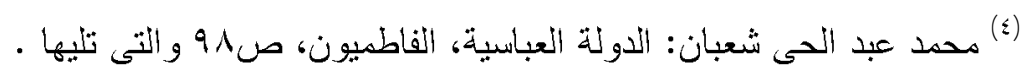

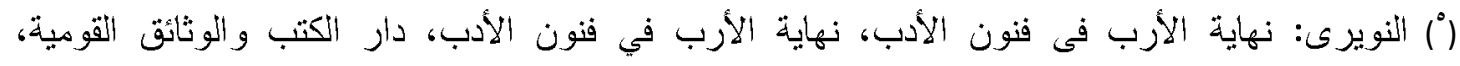

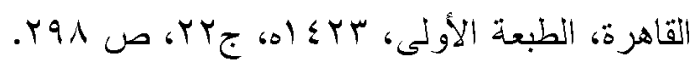


هو التعاطى السياسى للشاكرية التى خرجت عن الإطار المنوط بها وصارت تثارك فى صنع القرار

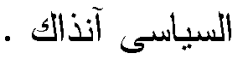

وحسبما تشى به مجريات الأحداث السياسية التى أظهرت دوراً ملحوظاً لفئة الثاكرية فى أعقاب

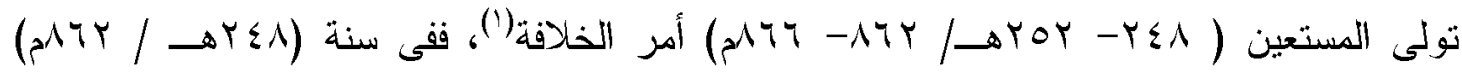
وبعد مبايعة المستعين بالله بالخلافة ، وفى مستهل عهده تحركت جماعة من الثاكرية والغوغاء

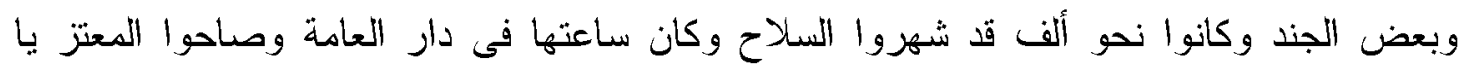

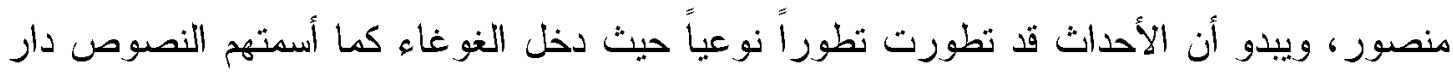

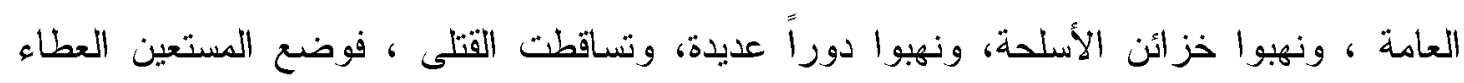

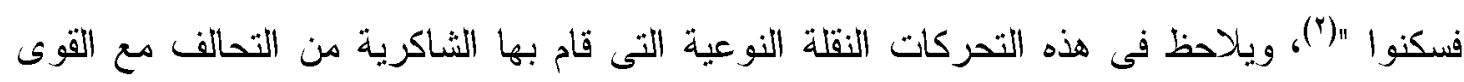

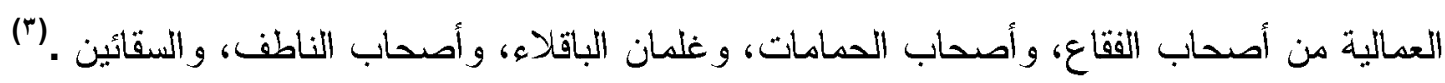
ومن الجدير بالذكر فإن هذه الإشكالية هى أحد أبرز الدوافع التى تحكمت فى تحركات الثاكرية وهو

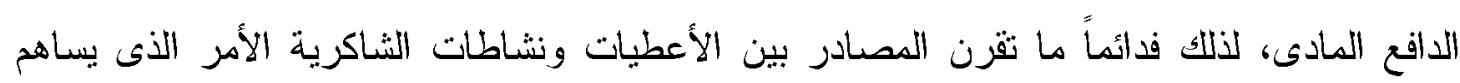
بوضوح فى رسم معالم واضحة للعقيدة العكرية للثاكرية .

وفى الواقع فقد تم توظيف الثاكرية من قبل أطر اف أخرى لتصفية خصومه السياسيين، ويمكننا أن

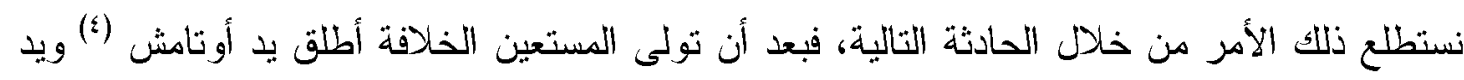

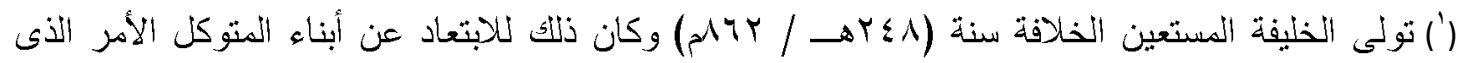

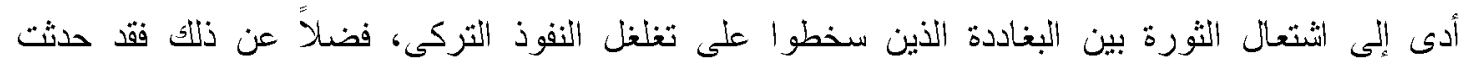

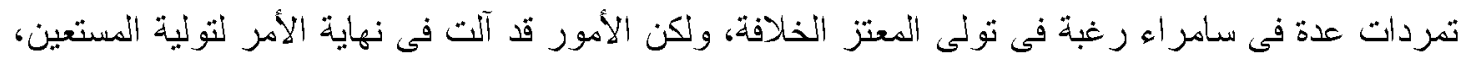

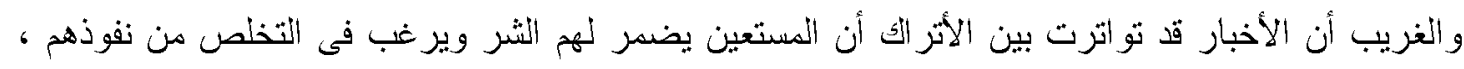

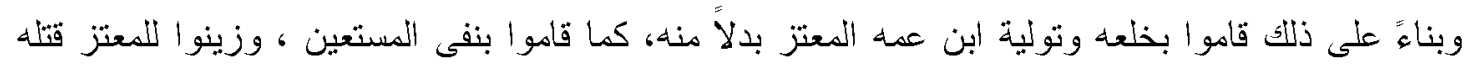

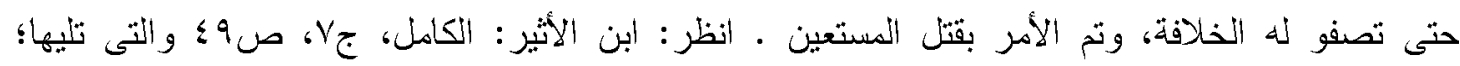

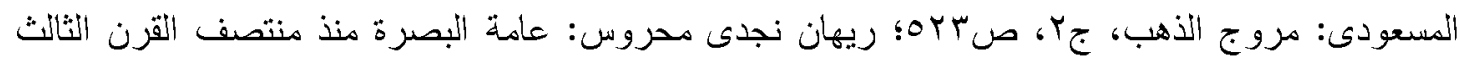

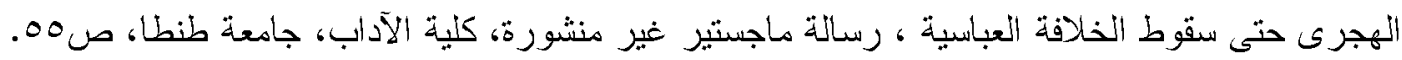

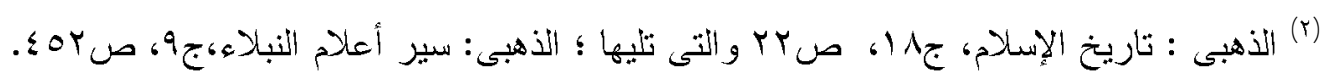

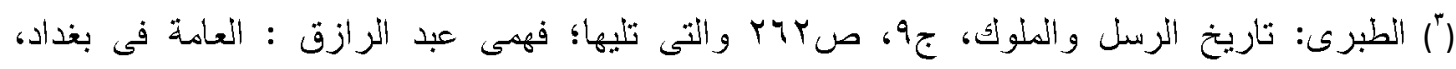

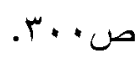

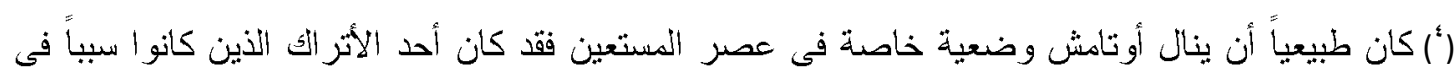

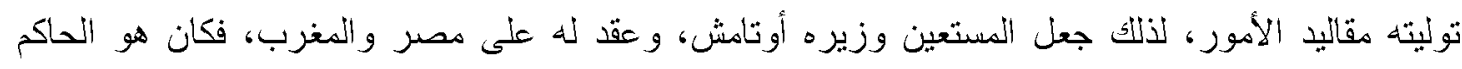


شاهك الخادم فى بيوت الأمراء، وفعل أوتامش التركى الأمز ذاته، الأمر الذى أثر سلباً على نفوذ

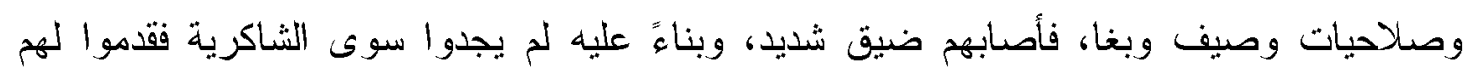
العديد من الإغراءات ليخلصوهم من هذا المنافس السياسى الصلب، وبالفعل تحركت قوات الثاكرية،

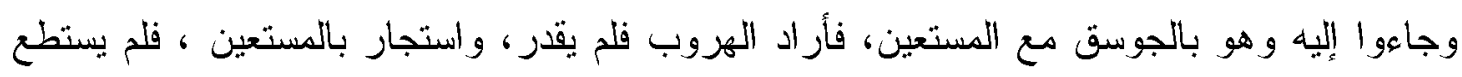

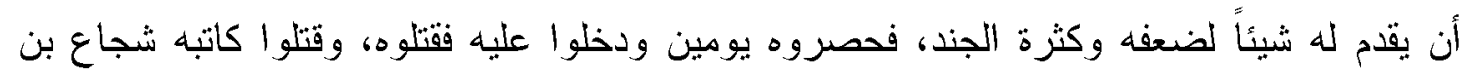

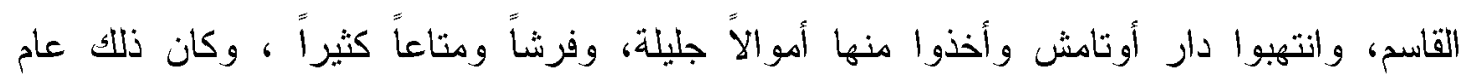

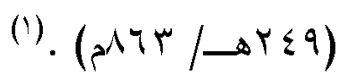

وفى الحقبقة وحسب بعض التفسيرات فقد كان هناك دوافع أخرى لاى الثاكرية فى التخلص من

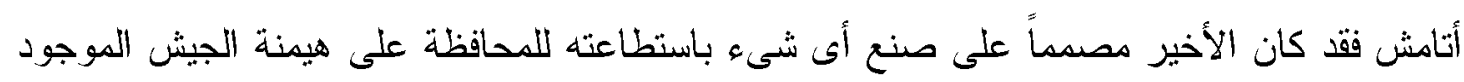

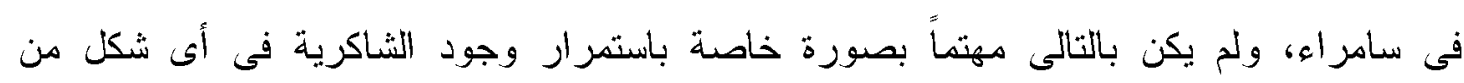

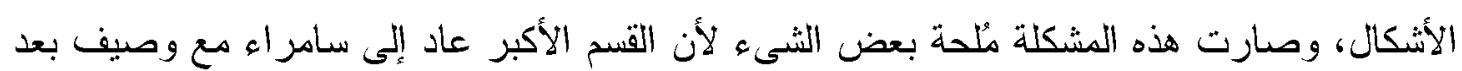

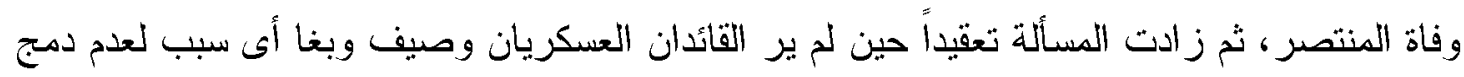

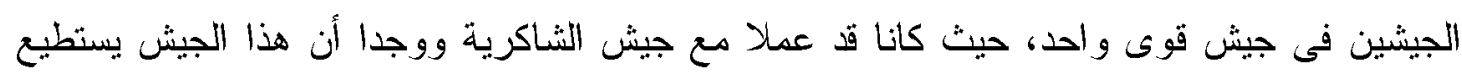

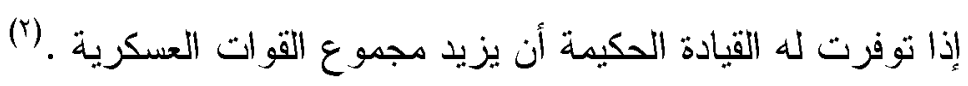

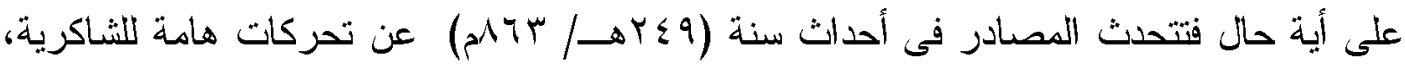

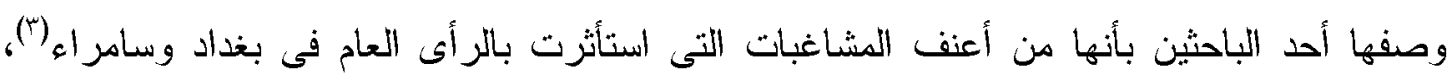

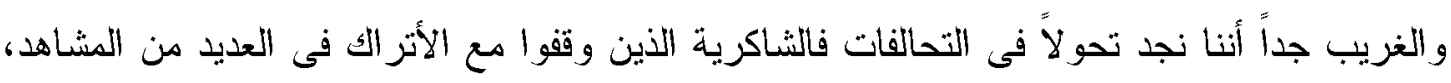

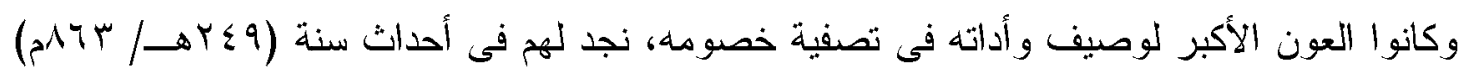
ظهوراً مختلفاً، ففى هذا العام شغب الجند والثاكرية وتتفق النصوص على أسباب تحرك الثاكرية

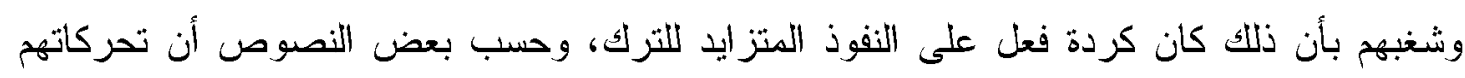
كانت لما رأوا استيلاء الترك على الدولة يقتلون من بريدون ويستخلفون من أحبوه، من غير ديانة ولا

الحقيقى إذ فوض إليه الأمور وأطلق يده فى بيوت الأموال ومعه شاهك الخادم ـ انظر : محمد على حيدر:

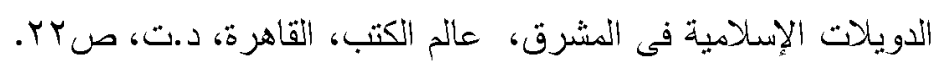

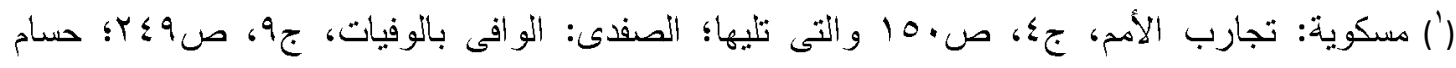

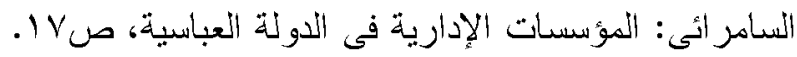

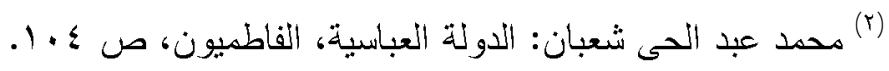

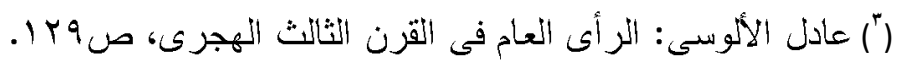


نظر للمسلمين، ولا من غير مصلحة ومن المثير أن هذه الأحداث قد تطورت تطوراً نوعباً خطبراً،

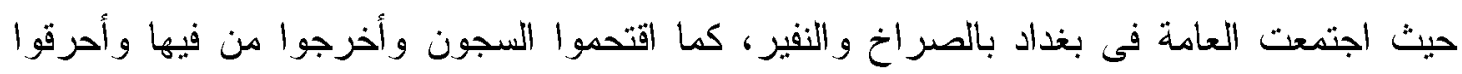

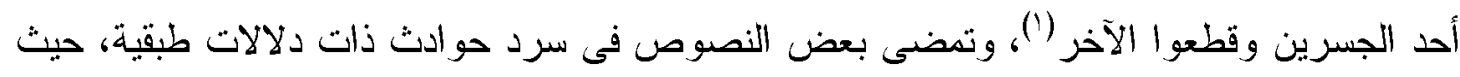

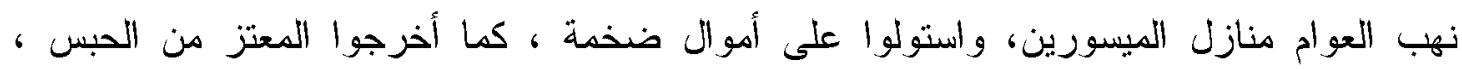

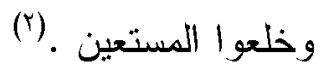

وفى الواقع فإن إسناد دور البطولة للعوام ومن عاونهم من الثشاكرية فى مسألة خلع المستعين هو أمر

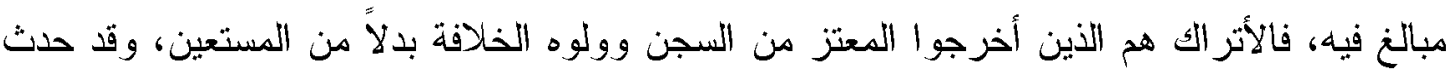

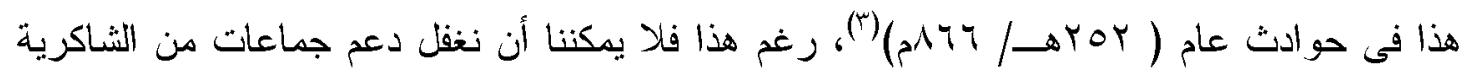
لطرفى النزاع دون تبنى قضية سياسية محددة سوى قضية المال و المصالح . على أبة حال فحسب روايات أخرى اتفقت على نفس الأحداث السابقة التى أدث لحوادث عام

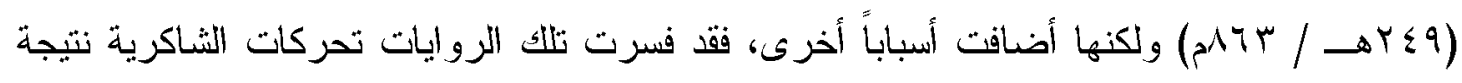

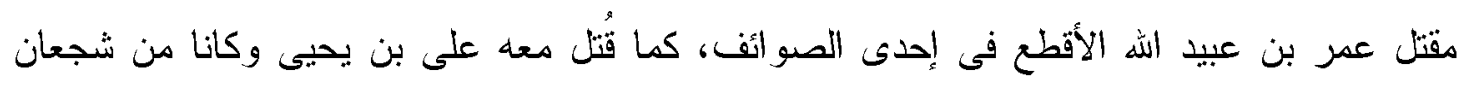

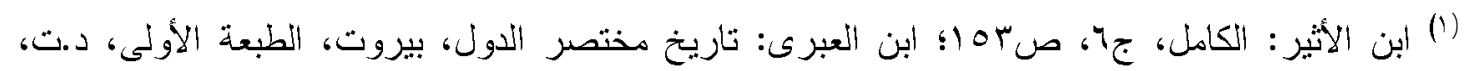

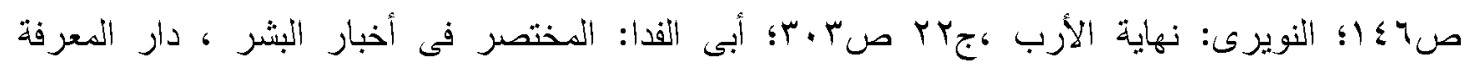

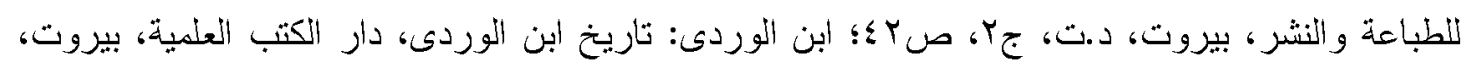

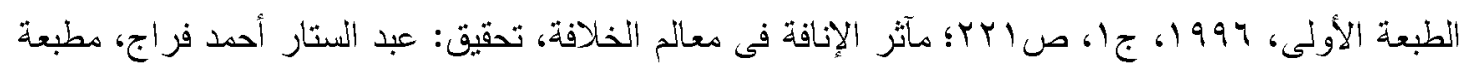

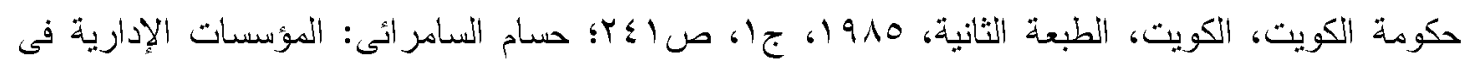

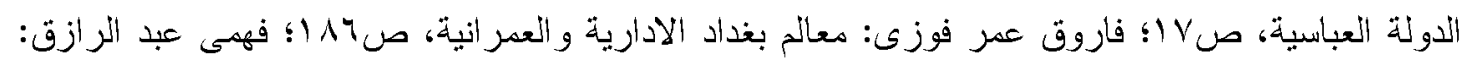

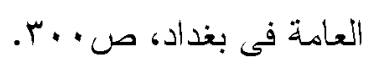

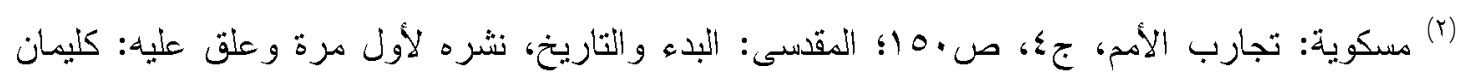

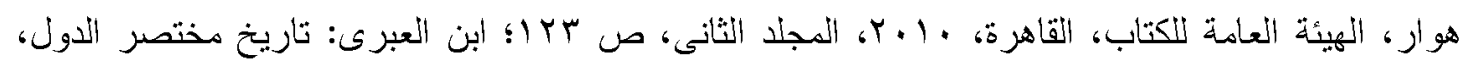

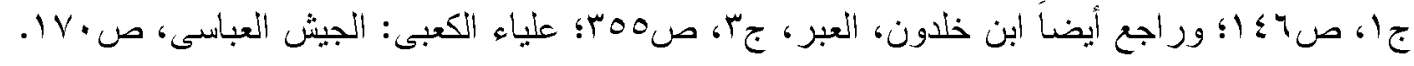

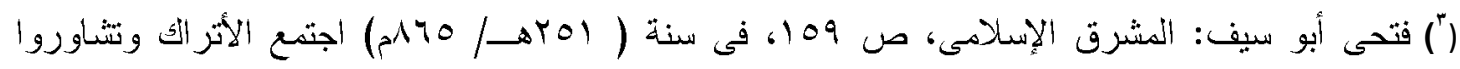

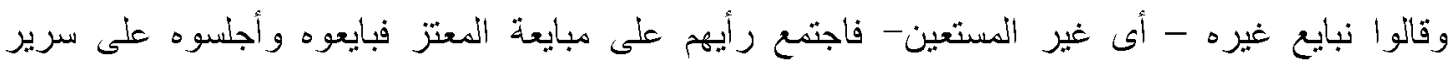

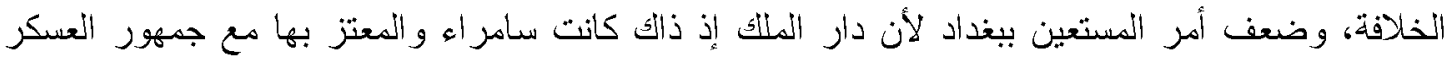

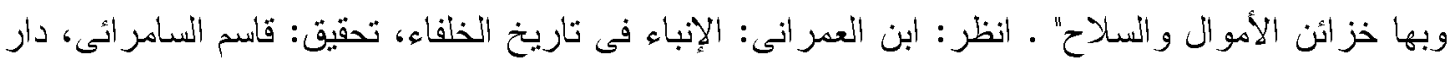

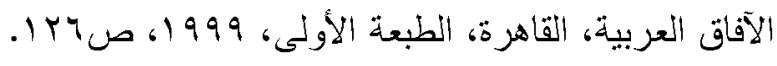


الإسلام، وقد عظم شأنهم فى القتال فى الثغور، فضلاً عن استعظام الشاكرية لقتل الأتراك للخليفة (المتوكل . (1)

أما ابن خلدون فقد صاغ الحادثة صياغة تعطى لنا تفسيراً مختلفاً تماماً عن التفسيرات السابقة فقال " لما اتصل الخبر ببغداد وسامر اء بقتل عمر بن عبيد الله الأقطع وعلى بن يحيي شق ذلك على الناس لما كانوا عليه من عظيم الغناء فى الجهاد، واشتد نكيرهم على الترك فى غفلتهم عن المصالح وتذكروا قتل المتوكل، واستيلائهم على الأمور، فاجتمعت العامة وتتادوا بالنفير إلى الجهاد، وانضم إليهم الثاكرية يطلبون أرزاقهم"(r)، وهو ما ذهب إليه نص آخر بأن العامة قد اجتمعوا فى بغداد بالصر اخ والنفيز، وانضدت إليهز الثاكرية تظهر أنها تطلب الأرزاق(ّ)، وحسب تفسير آخر أن التحركات كانت قد قادت بالفعل، وأن ما أذكى هذه الانتفاضة وزاد من أسبابها وصول خبر مقتل عمر الأقطع، و على بن يحيى (๕).

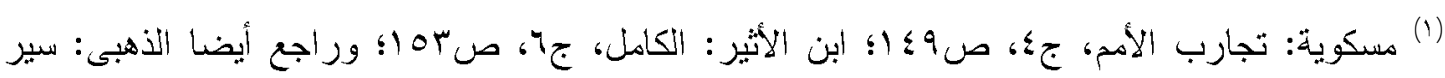

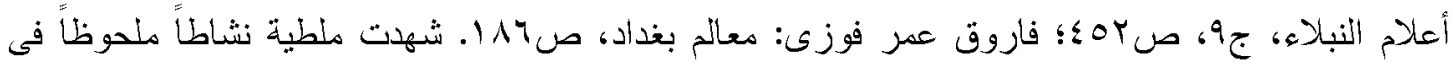

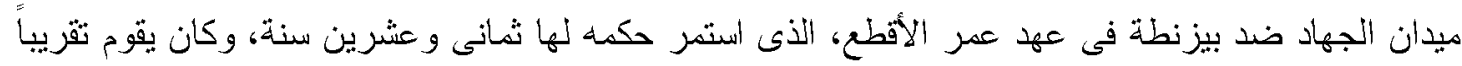

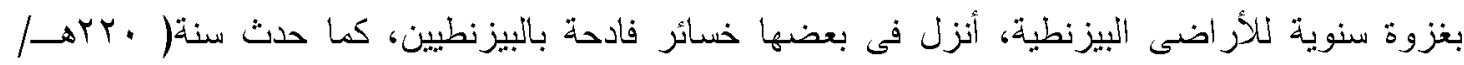

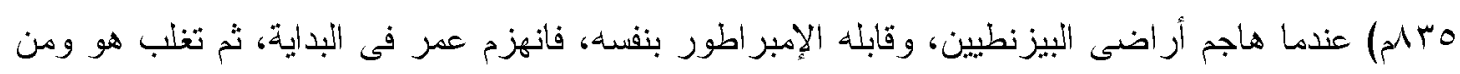

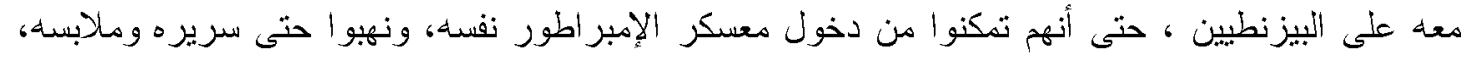

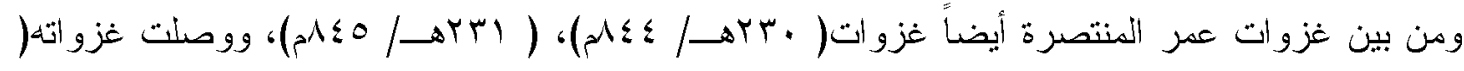

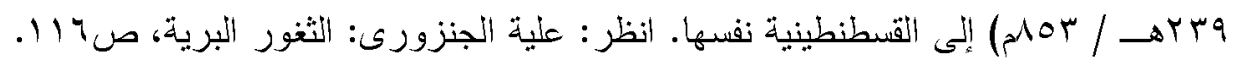

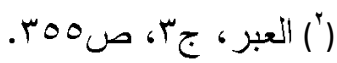

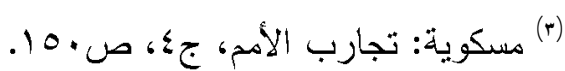

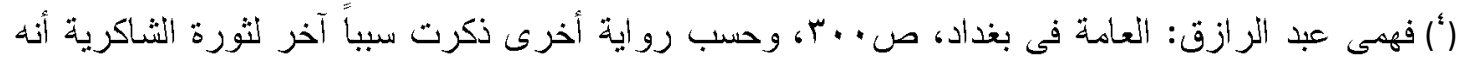

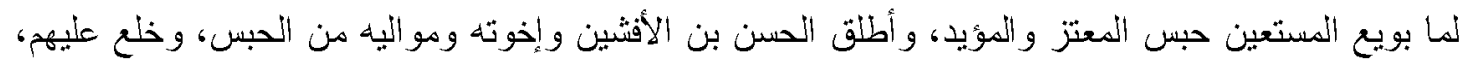

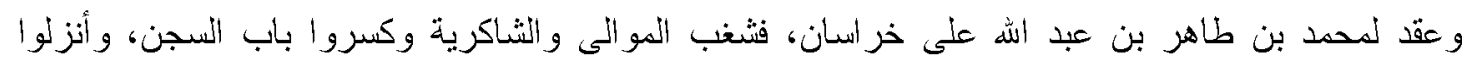

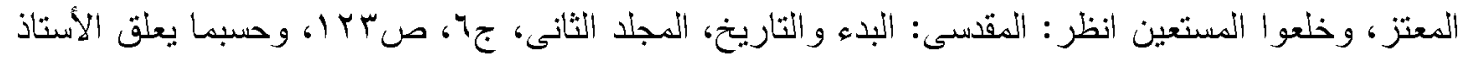

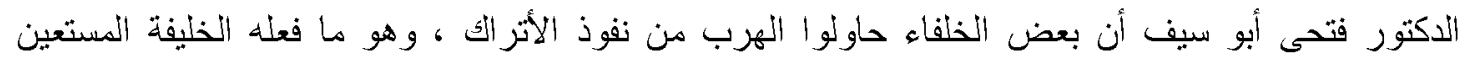

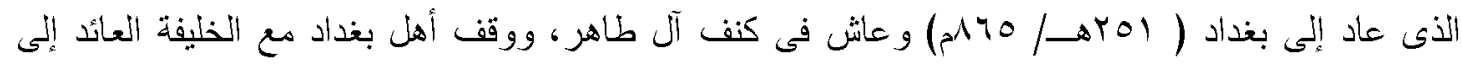

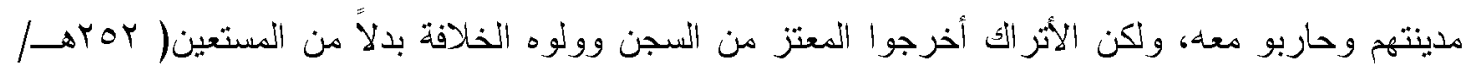

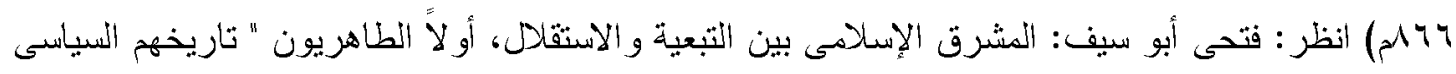

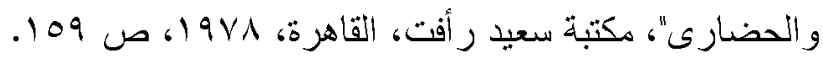


وبذلك فإن نص ابن خلدون يوضح أن الأسباب الدذكورة كلها لم تكن هى الدافع الذى حرك الثاكرية،

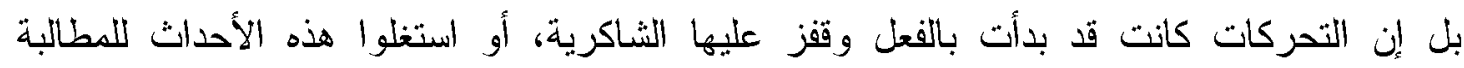

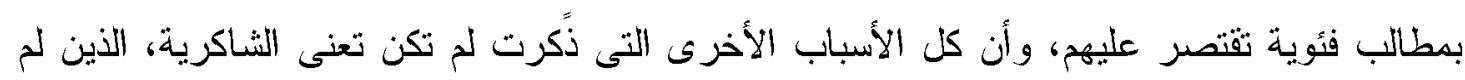

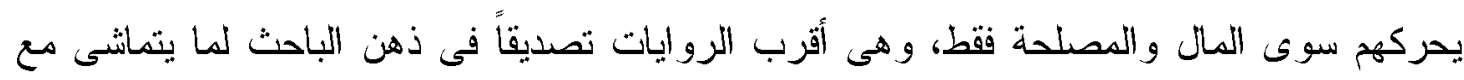
طبيعة الثاكرية وعقيدتهم العسكرية (1)، وخصوصاً لو رصدئ لونا تحركات الشاكرية السابقة، وكونهز

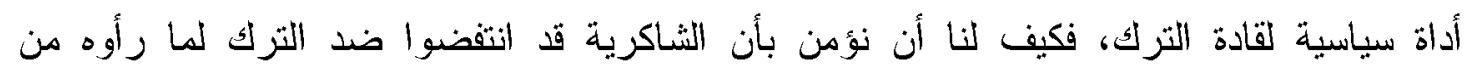
المصلحة العامة، ورغم يقين الدراسة أننا لسنا أمام جماعة واحدة من الثاكرية، وهو ما ذهبت إليه

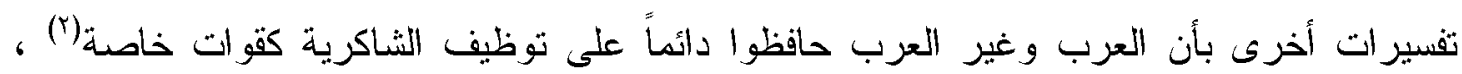
وبذلك فإن فكرة تبنى الثاكرية لقضية ما والاستجاثة لأجلها أبعد ما يكون عن توصيف الثاكرية، تلاك الفئة التى لا يمكن تفسير تحركاتها إلا فى إطار برجماتى قائم على المصلحة المادية فقط. وكما ذكرنا سابقاً فإن دور الثاكرية قد تطور بشكل كبير ، فلم يستمر الثاكرية كقوات مرتزقة،

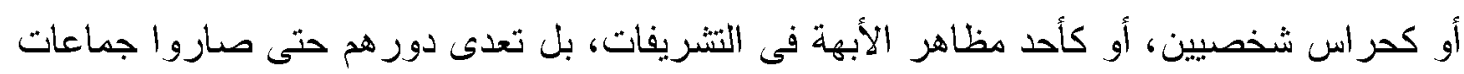

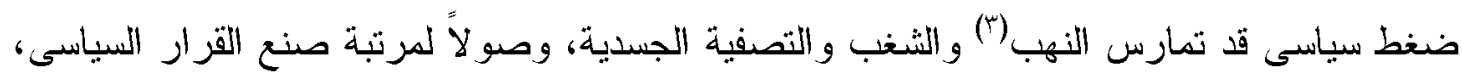

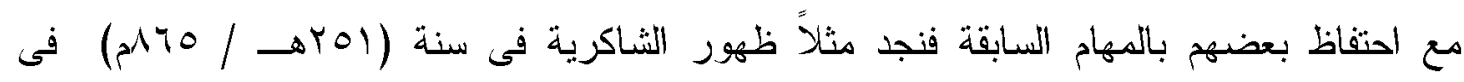

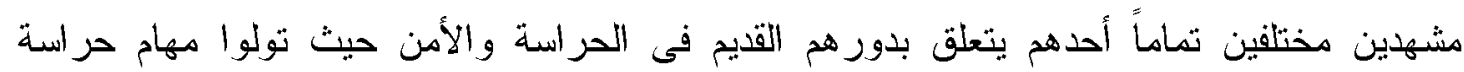

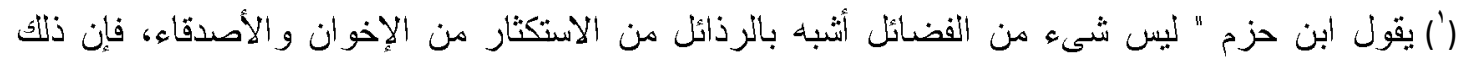

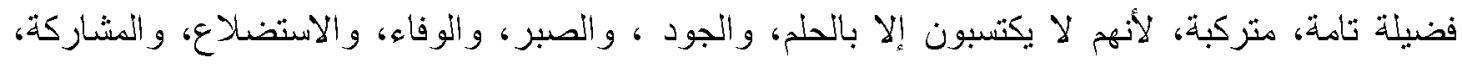

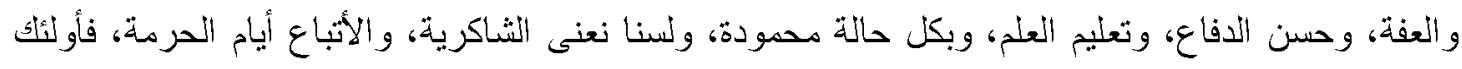

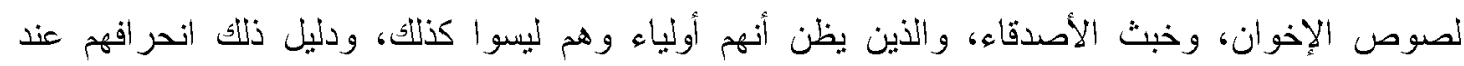

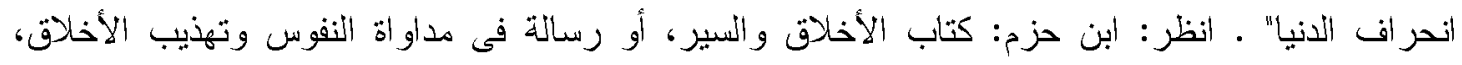

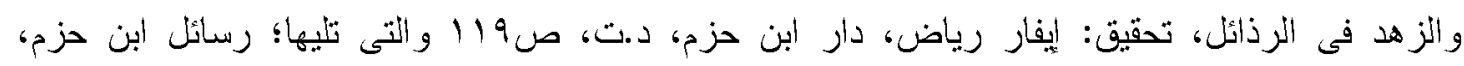

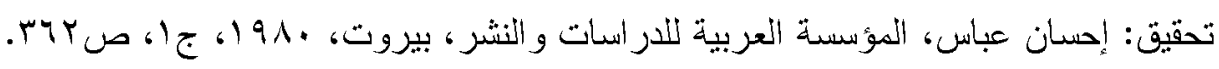
KHALIL , AL-SHAKIRIYYA, The Encylopadeia of Islam, ,p250.

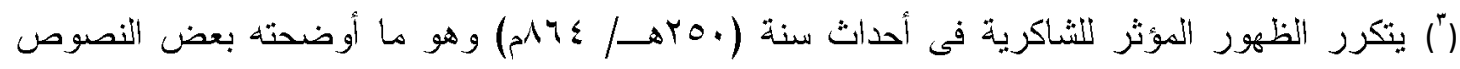

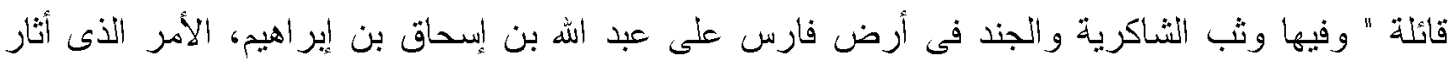

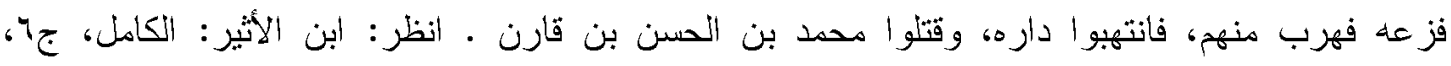

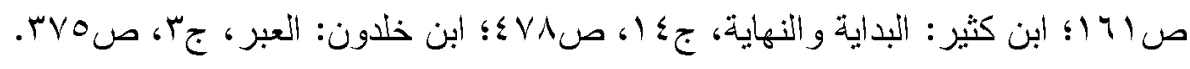


الطريق لمكة(1)، والآخر يمثل قمة المشاركة فى القرار السياسى فى الدولة العباسية فخلال الصراع السياسى بين المستعين والمعتز سنة ( (0بهـ / هبامج) ساندت جماعة من الثاكرية الخليفة

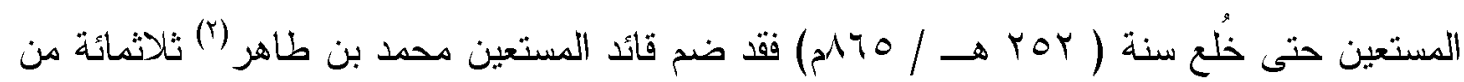

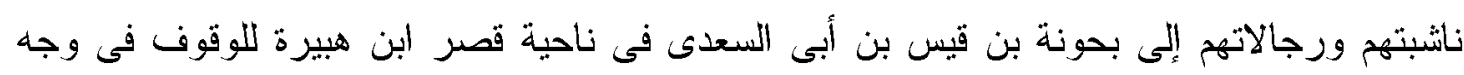
الأتراك، ولما حاول المعتز استمالة بعض عناصر جند المستعين إلى جانبه رفض الثاكرية ذلك رغم موافقة بعض العناصر الأخرى (")، وبناءٌ على ذلك أمر الخليفة المستعين بصرف العند العطاء

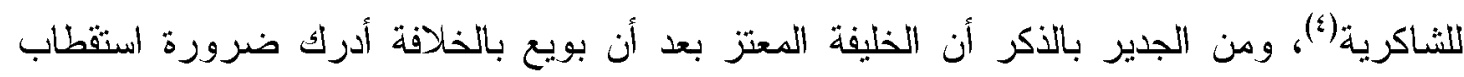

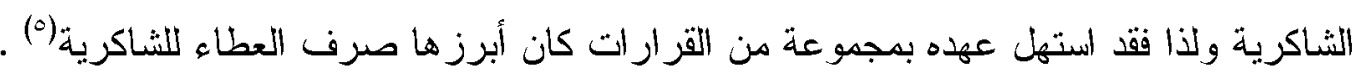

(1) الطبرى: تاريخ الرسل و الملوك، جو، صبهوب؛ العزى: النزاع بين قادة الجيش الأتراك و الخلافة

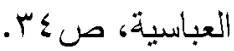

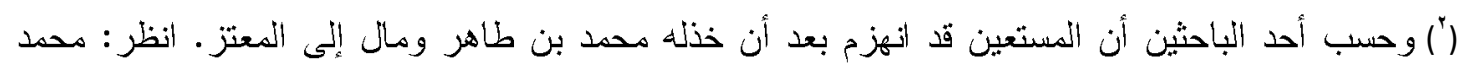

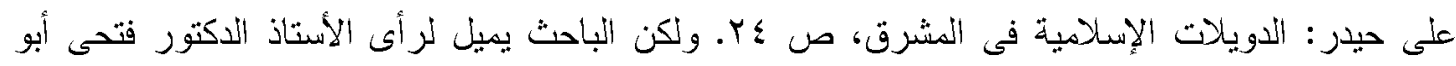

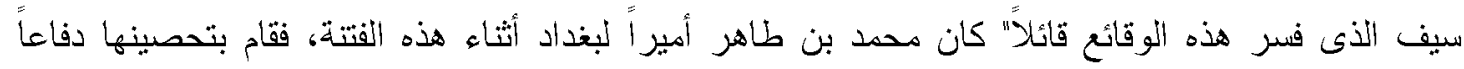

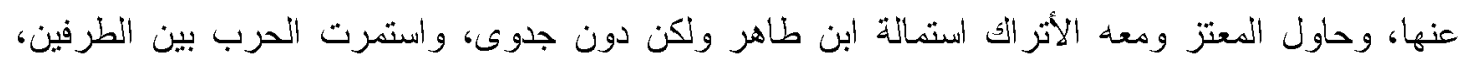

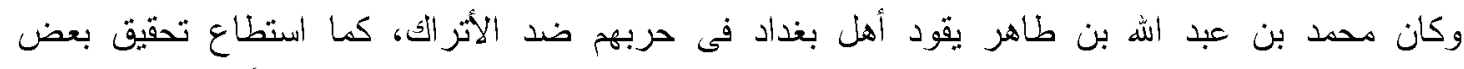

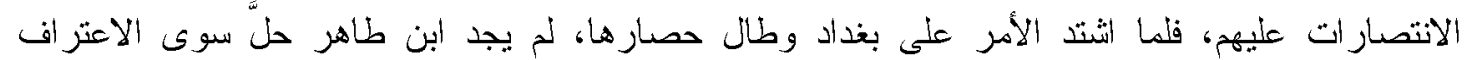

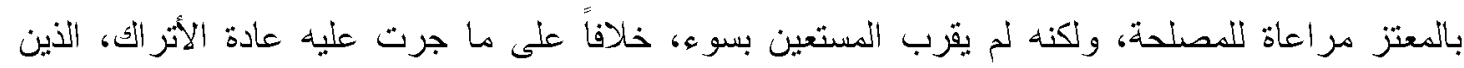

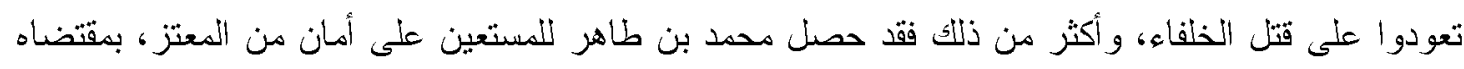

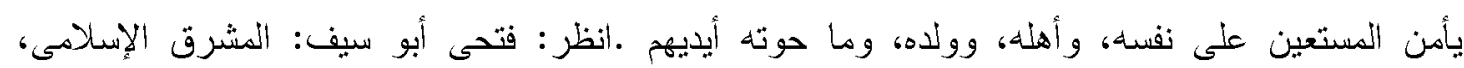
ص. n

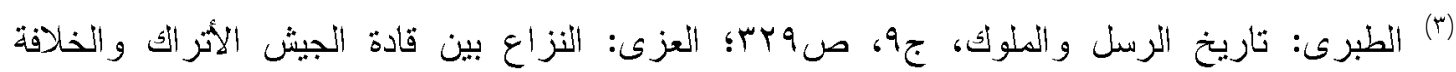

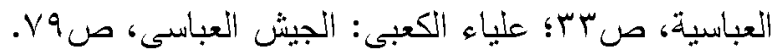

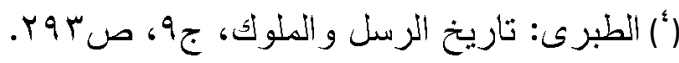

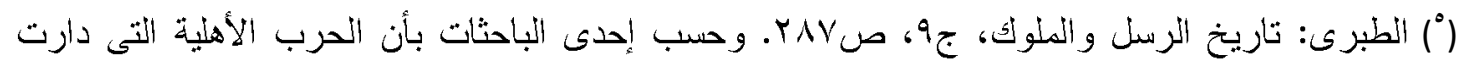

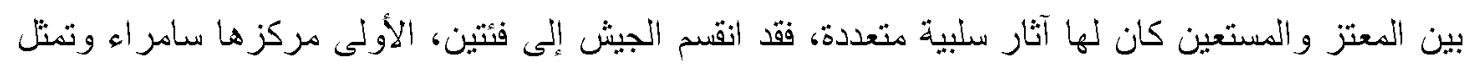

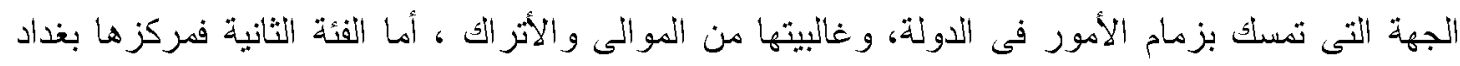

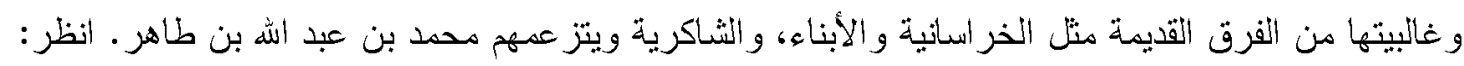
علياء الكعبى: الجيش العباسى، صبه و التى تليها، وإن كان الباحث يتحفظ على هذا التحليل وذلائك لأن

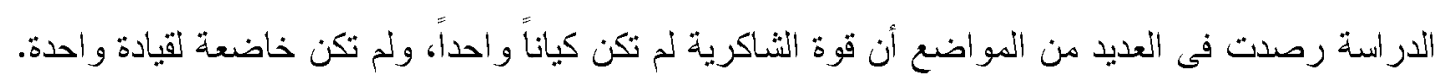


وفى واقع الأمر فإن الباحث يعود ليؤكد بأن المال كان المتحكم الرئيسى فى تحركات الثاكرية ،

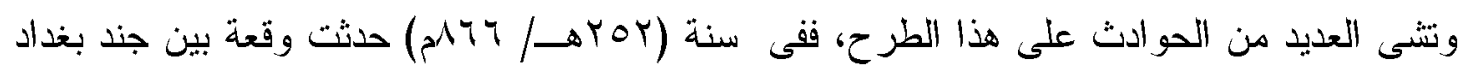

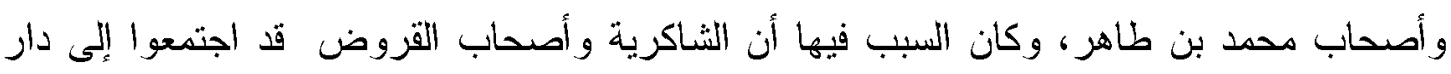

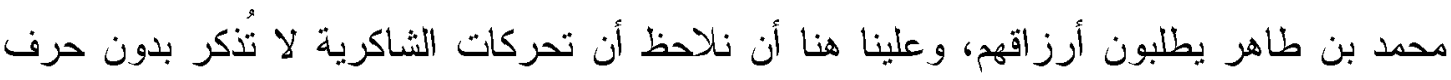

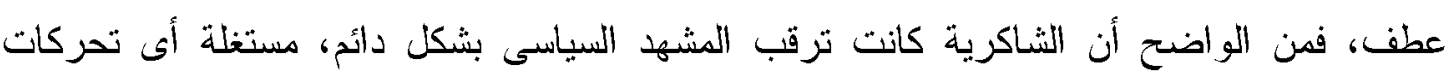

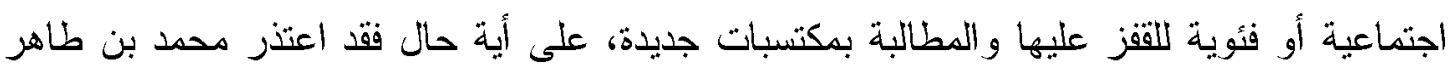

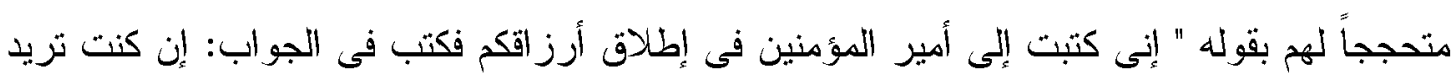

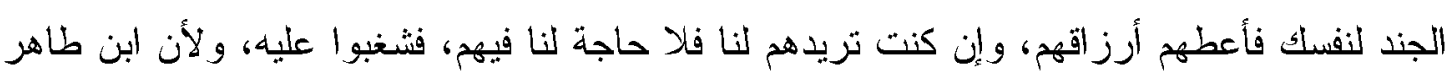
يعلم جيداً دفتاح الثاكرية فأخرج لهم ألفى دينار فسكتوا، ولكن المال الذى تم توزيعه لم يكن مرضياً.

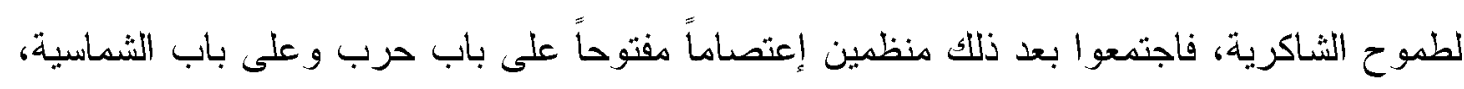

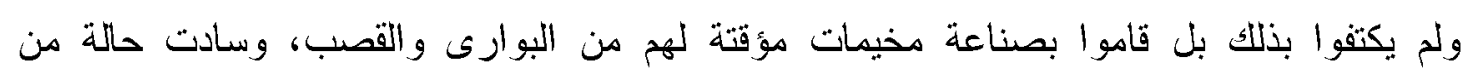
الفوضى حيث انضمت لهم عناصر أخرى، وقرروا منع الخطيب من خطبة الجمعة، كثكل من أشكال

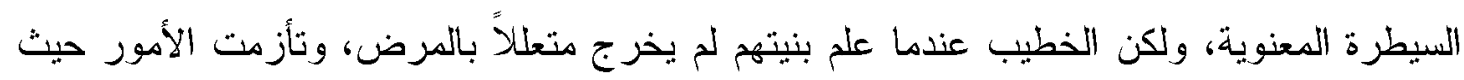

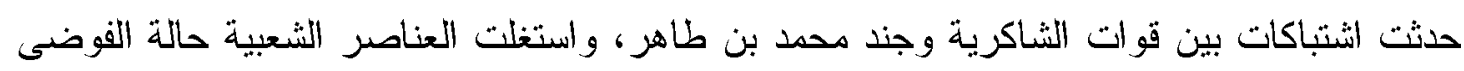

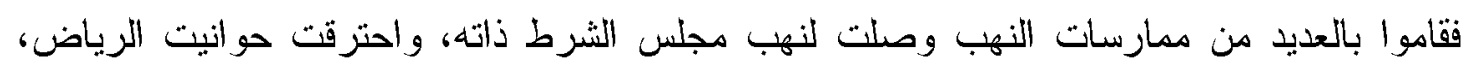
وتأزمت الأمور على ابن طاهر ، ولكن ثمة انفر اجة قد حدثت بعد حدوث خيانة فى معسكر الثاكرية،

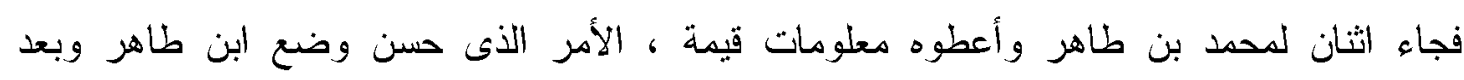

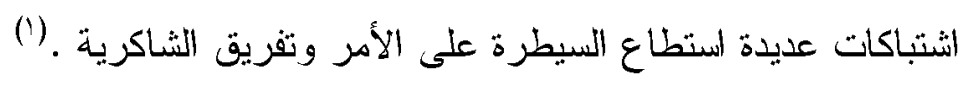

وقبل أن نتجاوز الحادثة السابقة علينا أن نتوقف قليلاً لمناقتشة بعض الششاهد الهامة فقد ألمحت

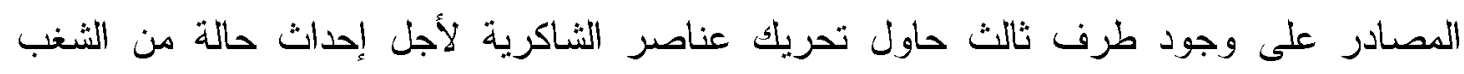

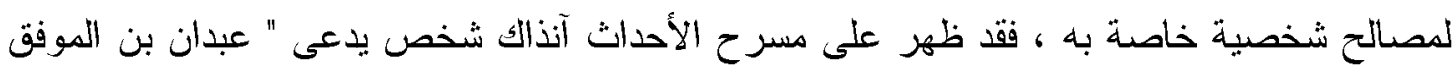
وشهرته أبى القاسم"، تروى لنا النصوص أنه باع داره بقيمة مائة ألف دينار، ولما وثبت الثاكرية

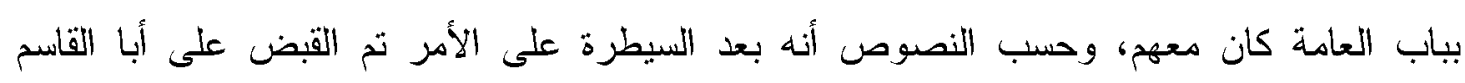

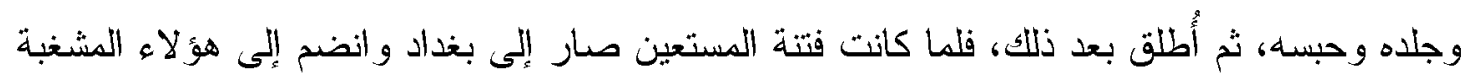

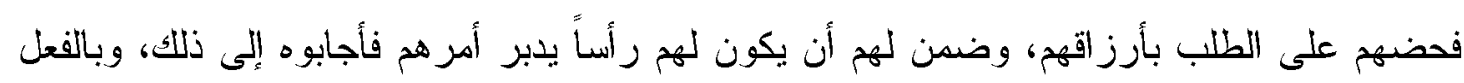

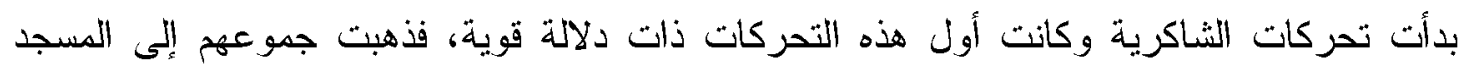

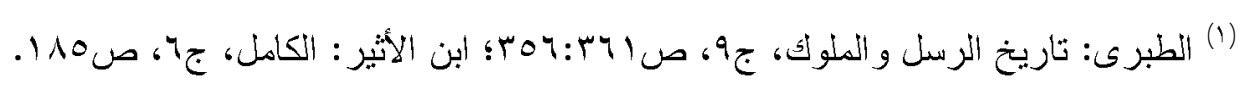


ومنعوا الخطيب من الدعاء للمعتز، وهنا وجه ابن طاهز إليهم قوات محدودة للسيطرة على الأمر،

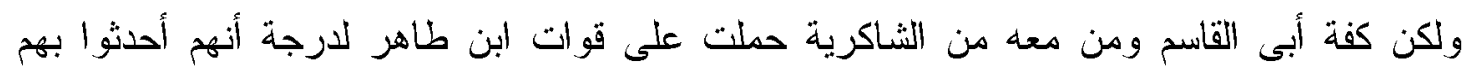
إصابات عديدة، وتظورت الأحداث وتدخل ابن طاهر بنفسه وعبأ قواته تعبئة الحرب، فمالت الكفة ناحيته وتفرقت الثاكرية وتم القبض على أبى القاسم عبدان بن الموفق وفى النهاية حُكم عليه بالصلب (1). حتى مات ونغرن

وفى الحقيقة فإن هذه الحوادث بالغة الأهمية كونها كاثشفة للعديد من الأمور التى تفسر سلوك

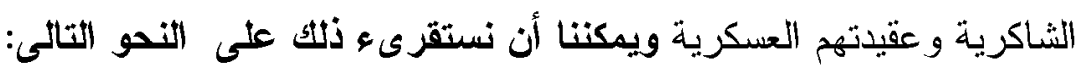
أولاً: بلا شك كانت هناك أزمة قيادة لقوات الثاكرية، فكان أحد عو امل ضعف الثاكرية، فتعرضوا للاستقطاب بشكل واضح وهو ما اتضح من أبى القاسم عبدان عندما ضمن لهم أن يكون لهم رأساً

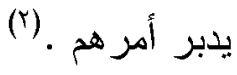

ثانياً: تبرز أكثر النقاط أهمية عند سيطرة قوات ابن طاهز على الأحداث، فقد كان أحد قادته يدعى

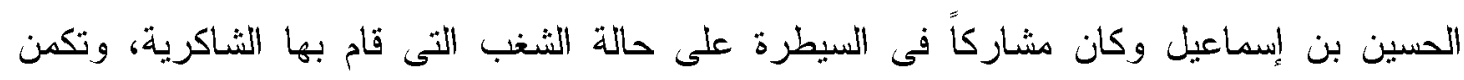

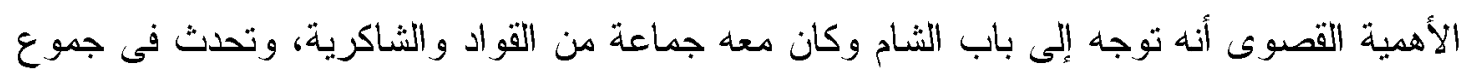

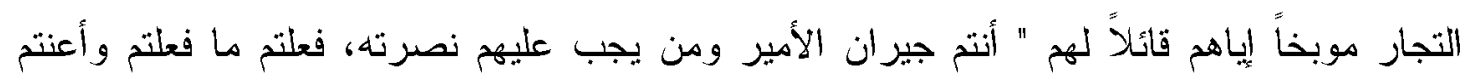
الثاكرية عليه "(").

وفى الحقيقة فإن مكمن الأهمية تبدو عند قراءة النص قراءة متأنية، فالحسين بن إسماعيل كان معه قو اده و الثاكرية، وهو أحد القادة الذين قامو ا بالسيطرة على شغب الثاكرية، وبعد أن انتهى من الأمر

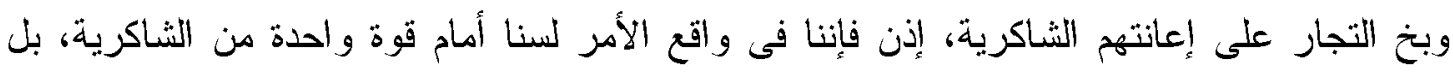
قوات متعددة القيادات، ولاينا نصوص واضحة تعضد هذه الإنشالية مثل ما ذكره الطبرى سنة

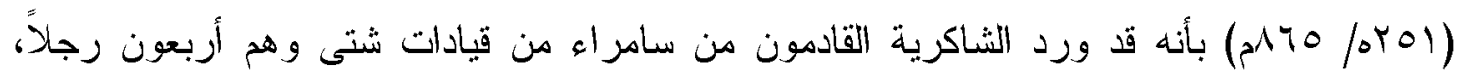
وعلينا هنا أن نربط بين كلمتى قيادات شتى ورقم أربعين رجلاً، أى أن عدداً بسيطاً مثل أربعين

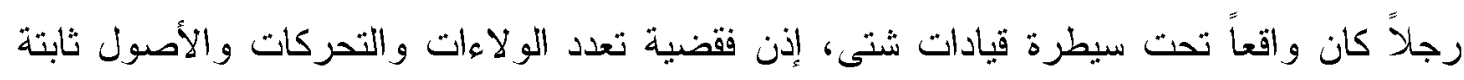

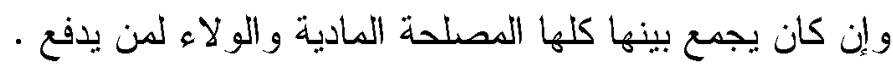

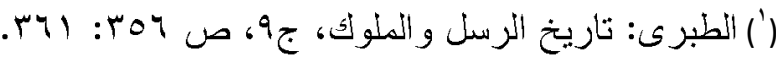

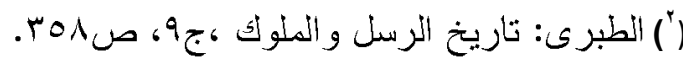

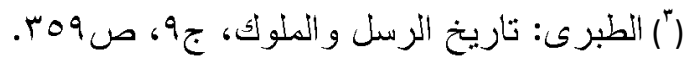


ثالثثاً: كانت مسألة الو لاء لمن يدفع، أو التحرك لأجل المال مسألة محسومة ومعروف لجميع أطراف

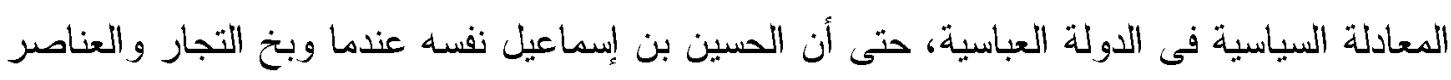

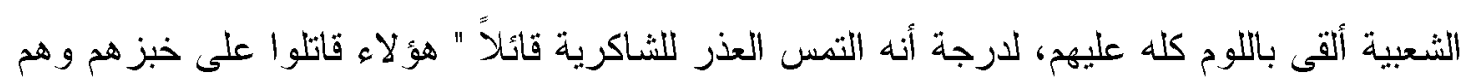

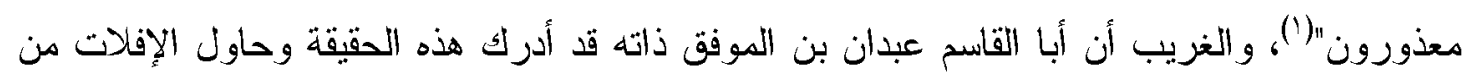

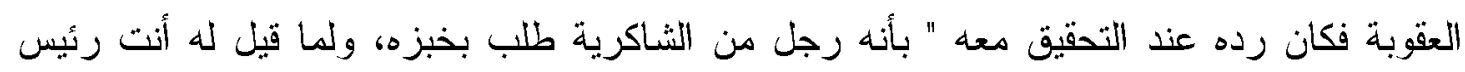

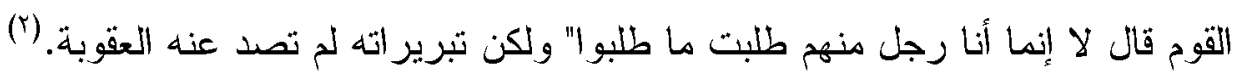
ومهما يكن من أمر فقد استقرت الدراسة على أن نزوع الثاكرية فى تحركاتهج لم يكن محسوباً على

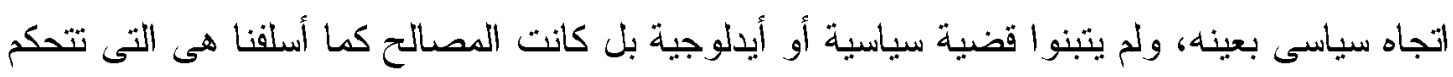

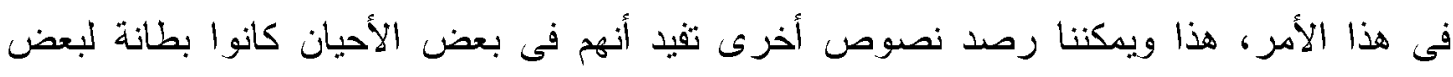

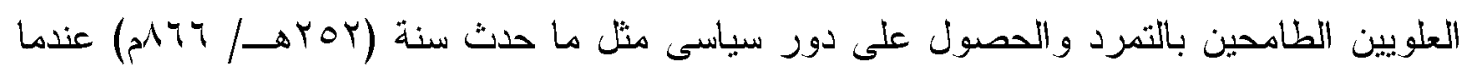

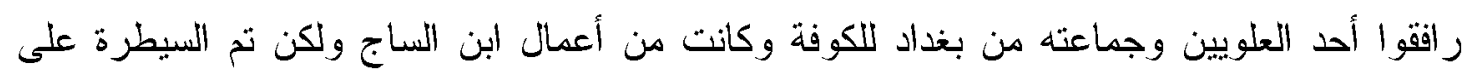

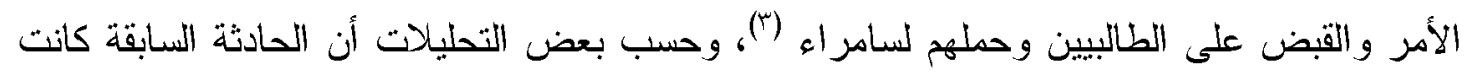
محاولة من الزيدية للاستفادة من تداعى السلطة الذى أعقب الحرب الأهلية بين أنصار المستعين

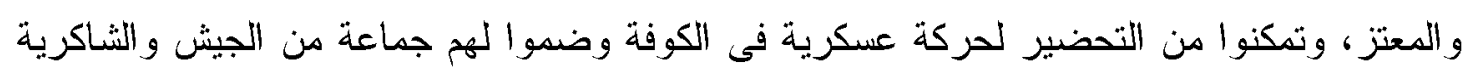

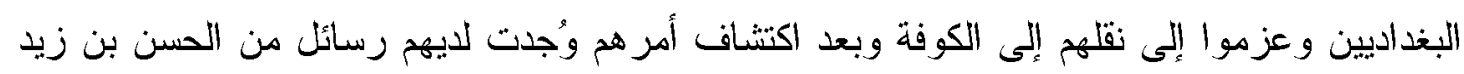

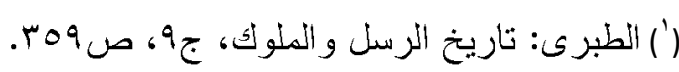

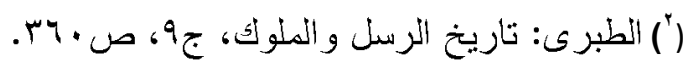

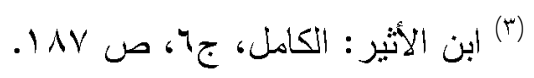

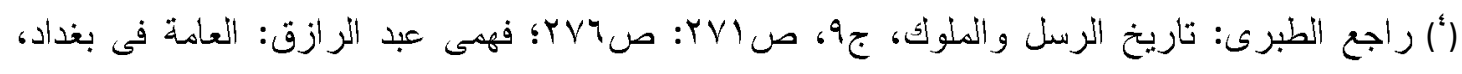

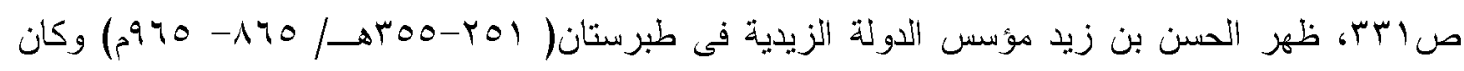

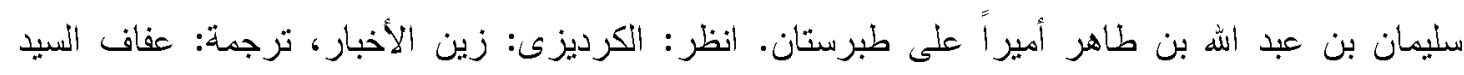

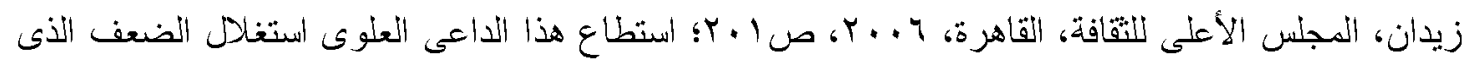

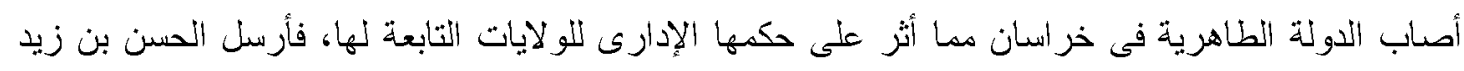

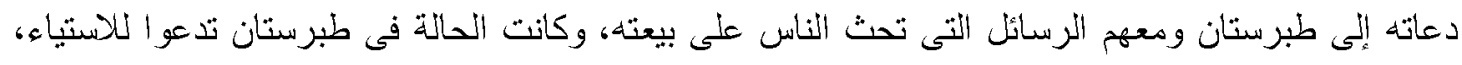

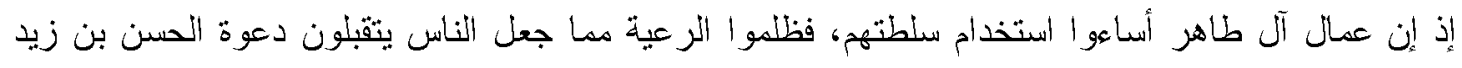

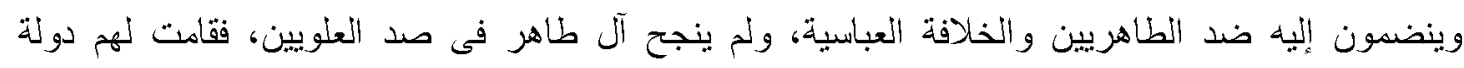

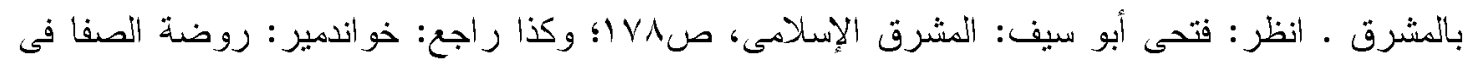

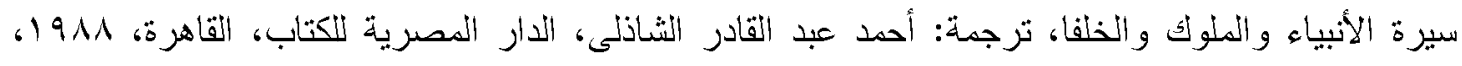




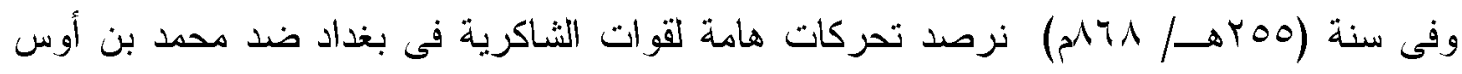

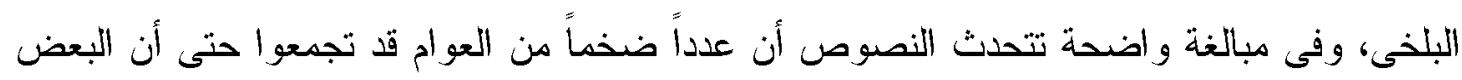
قد قدر عددهم بنحو مائة ألف، وحدثت أثتباكات عنيفة بين طرفى الصدام، (') وانتهى الأمر بهزيمة محمد بن أوس و أصحابه، ونهبت العوام ما وجدوه من أمو اله وكانت أمو الاًً ضخمة (؟).

وفى واقع الأمر فإنه لا يعنينا بحال أن نرصد تفاصيل الصدام بقدر ما يعنينا رصد تحركات الثاكرية ، وكان سبب تحركاتهم هذا العام هو محاربة صعاليك الرى الذين استقمهز سليمان بن عبد الله بن

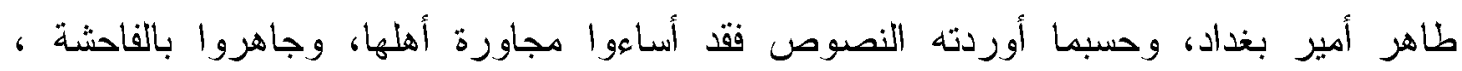

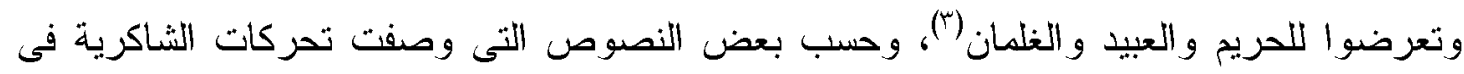

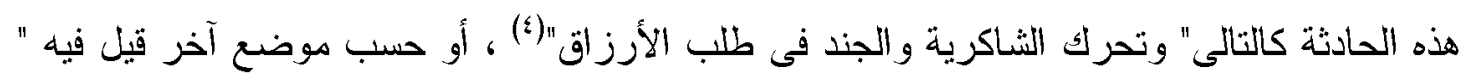

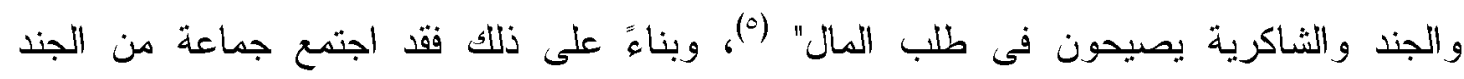

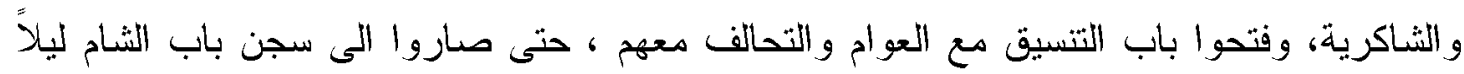
فكسروا بابه وأطلقو ا أغلب من كان فيه، ولو يبق من المسجونين إلا الضعيف والمريض و المثتل "(("). وعلينا التوقف قليلاً عند الحادثة السابقة فالحادثة بها تحركات للشاكرية وتحركات للعوام، وعلة للتحرك، فالعلة التى أعلنها النص هى ما قام به صعاليك الرى من إساءة الجوار، وارتكاب الفو احش،

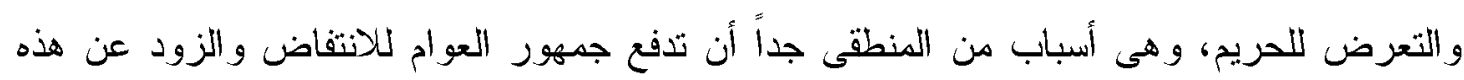

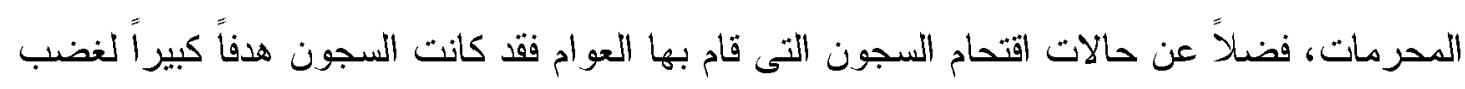

ص ا0، ولعل ضعف عمال الطاهريين على هذه الولاية من أهم العوامل التى مهدت الطريق أمام أعداء

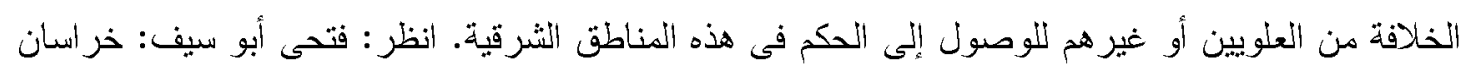

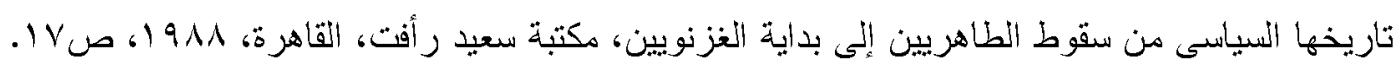

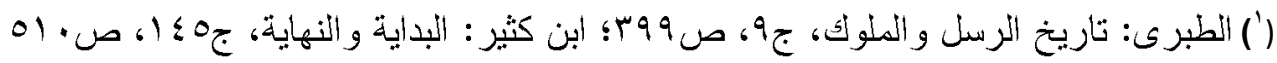

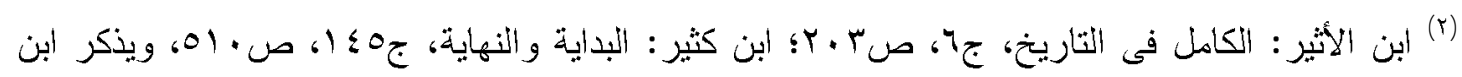

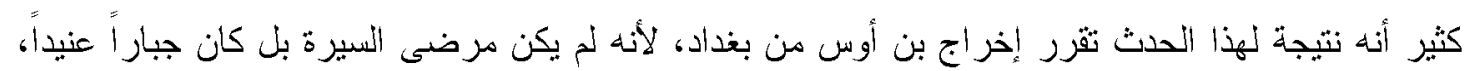

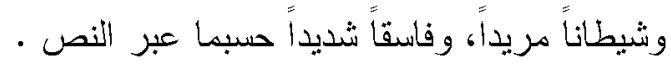

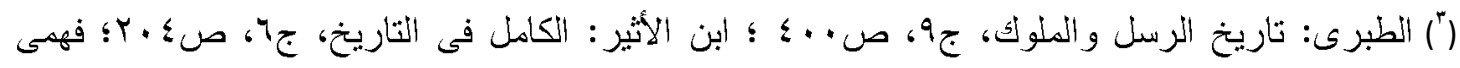

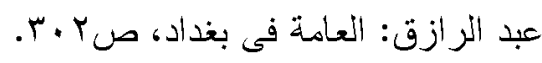

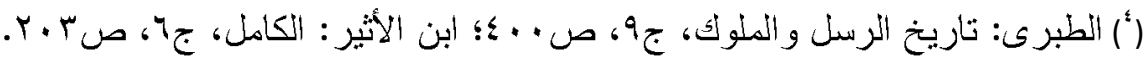

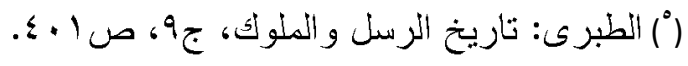

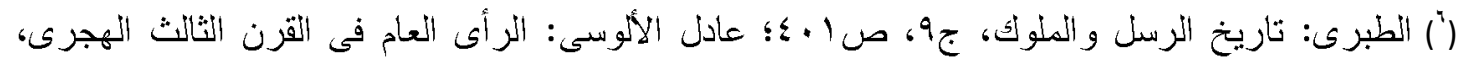

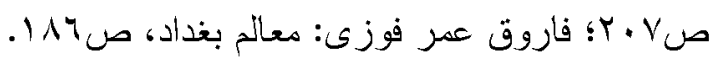


العامة وسخطها ، وكان سخط العوام على السجون تحديداً كما فسر أحد الباحثينً كونها رمزا للهيمنة و الطغيان والقهر (')، ولكن السؤال هل هذه الأمور هى التىى دفعت الثاكرية للتحرك؟ فى حقيقة الأمر فإن الباحث هنا لا يؤمن بأى حال أن هذه التجاوزات هى التى حركت الثاكرية، فقد تعودنا من

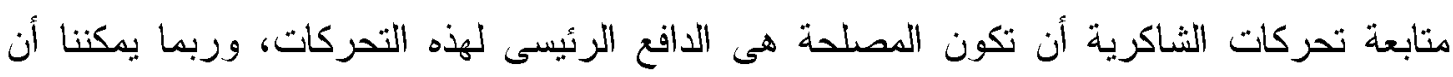
نصل لنتيجة مفادها أن وجود هؤلاء الصعاليك كان سيسبب حالة من حالات تضارب المصالح مع الثاكرية، وخصوصاً لو قر أنا ما صرح بـه الطبرى فى سياق حديثه أن هؤلاء الصعاليك كانوا حر اساً

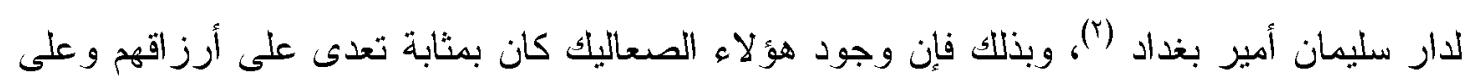
وظائهم التى يرتزقون منها، ولذلك كان استغلاله لتحركات العوام للتصدى لهذا الفصبل الجديد، و هو ما قام به الثاكرية دائماً من عقد تحالفات مع العوام وغيرهم لتحقيق دصالحهم ببز اجماتية شديدة.

لقد كانت كل الحوادث التى انخرط فيها الشاكرية تدلل بوضوح أنهم شكلوا فصبلاً رئيسياً فى معادلة القوة والنفوذ إبان فترة الدراسة، وكان ضمان خدماتهم عاملاً من عوامل فرض القوة، ففى سنة ( ثارت عساكر الثاكرية التابعة لطاهر بن محمد بن عمرو بن الليث، ولحقته ببلاد

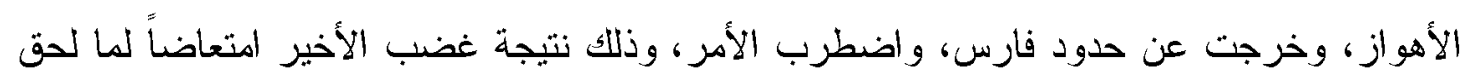
بجده عمرو بن الليث من إهانات، حيث تم تشهيره فى بغداد (")، ويبدو أن ممارسات عساكر

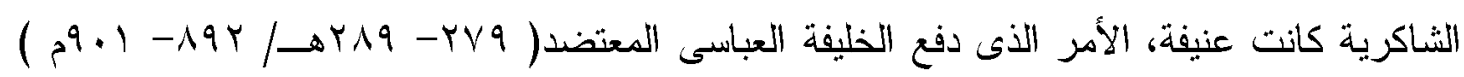
لمحاولة لحتواء السيطرة على الأمر ، فكلف قوات أخرى بالتصدى لهذا الأمر، ورصد لهم تمويلاً

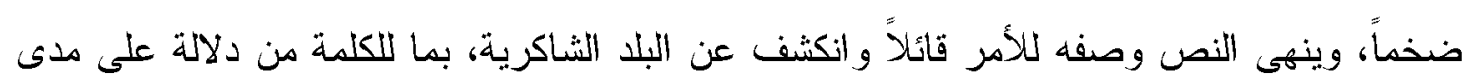
ما قام به النشاكرية إبان فترة الصدام.(๕) ومهها يكن من أمر فقد كانت هذه الحادثة أخر المشاركات

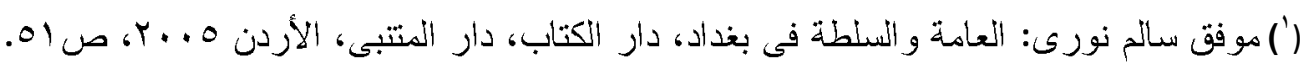

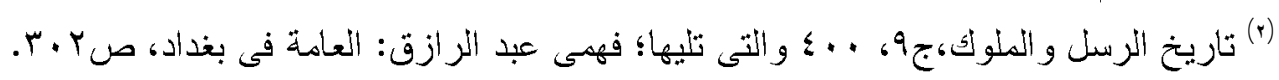

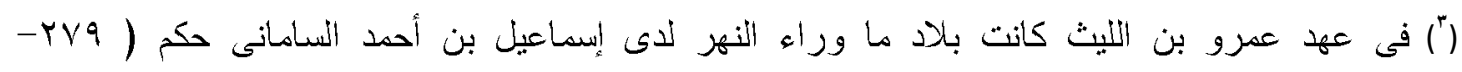

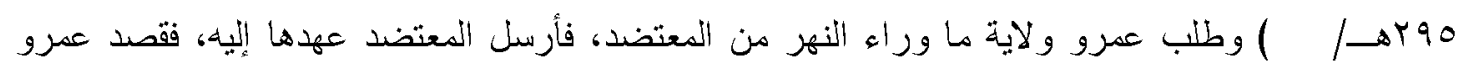

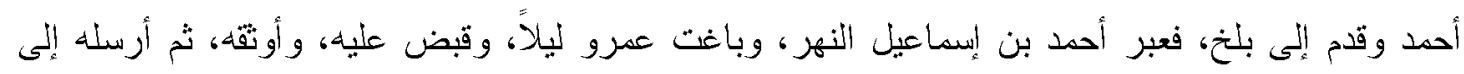

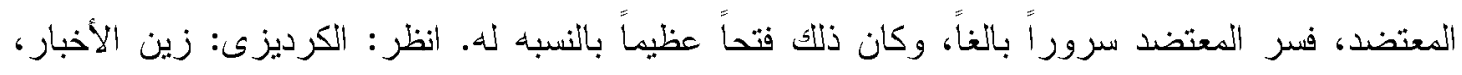

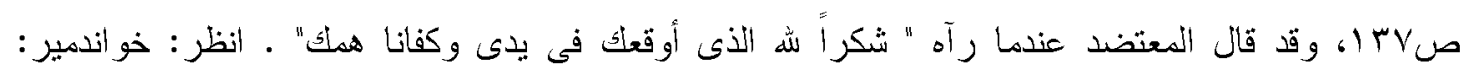

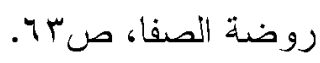

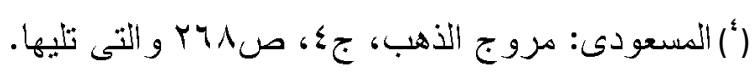


الواضحة للشاكرية إبان فترة الدراسة، بعد أن شغلت العديد من أحداث هذا القرن نشاطاً وتحولات

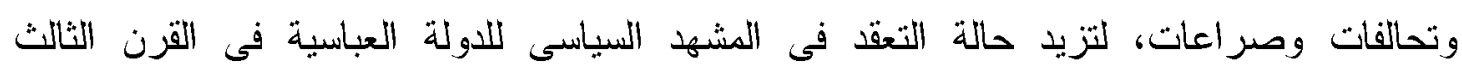

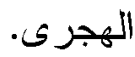

\section{الخلاصة :}

كان الدور الأول الذى لعبته النشاكرية على مسرح الأحداث التاريخية هو دور الخادم، أو

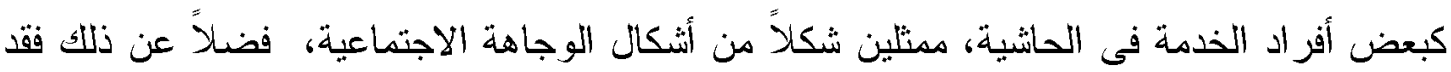

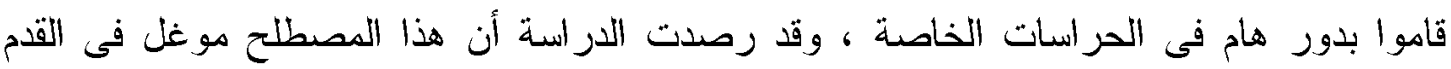

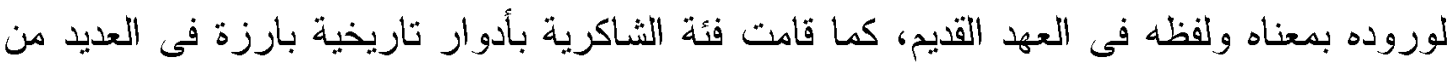

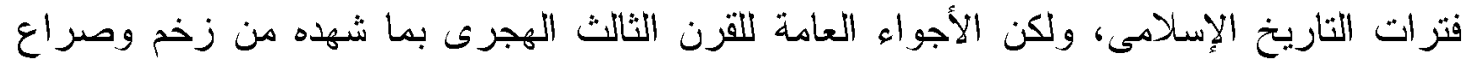
وتغييرات فى ميزان القوى كانت مناسبة لظهور الثاكرية على الساحة السياسية بشكل أكثر أهمية

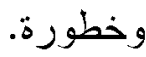
قامت فئة الثاكرية بدور آخر أكثر أهمية من مجرد الخدمة والحراسة، فقد شكلو ا فى العديد

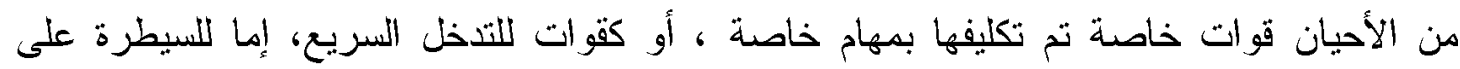

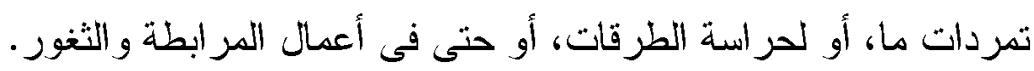

لم تنتمٍ فئة الثناكرية لإثنية أو عرق محدد، بل تنوعت أصول الثناكرية، فقد كانت كهيئة عسكرية مرنة تسمح بالانضمام إليها دون شروط محددة، الأمر الذى جعلها متعددة الو لاءات حسبما تقتضى المصلحة السياسية و المادية.

كان واضحاً بجلاء مدى الأهمية المنعاظمة للثاكرية من خلال النظم والرسوم الخاصة بهم، فقد حظيت هذه الفئة بوضعية مميزة فتم تخصيص دواب خاصة بهم، ومواضع سكنية، وملابس محددة، والأهم من كل هذا تميز هم على غير هم من القوى العسكرية فى الدولة العباسية بالعطاء، فكان

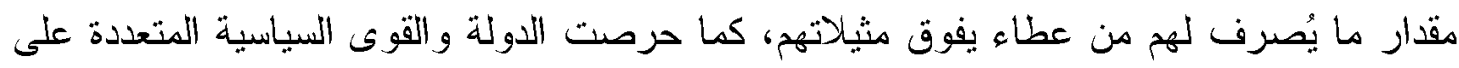
استقطابهر بالمال و الأعطيات فى كل المناسبات، إما لضمان خدماتهر، أو وقاية من تحر كاتهم. - يمثل الخليفة العباسى المتوكل علامة فارقة فى تاريخ الثاكرية، فالرجل الذى أدرك خطورة تحكم الأترالك فى صنع القرار ومسؤوليتهم عن انسداد الأفق السياسى للاولة العباسية أراد تفتيت القوة

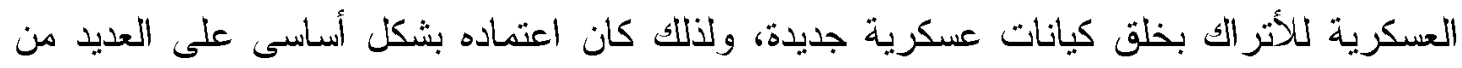


القوى الجديدة كان منها الثاكرية، فضلاً على تأكيده على أهمية الثاكرية فى مرسوم تولية أبنائه ولاية العهد، وورود اسم الثاكرية فى أكثر من موضوع من مواضع هذا المرسوم. - - كان وجود الثناكرية علامة من علامات السلطة والسيادة، وبالتالى كان التجريد منهم هو

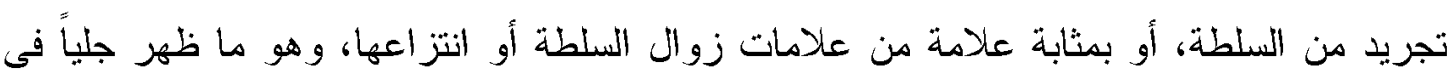

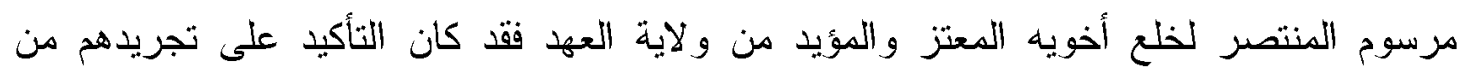
شاكريتهم و اضحاً كمظهر من مظاهر تجريدهم من و لاية العهد. كانت عناصر الثاكرية متخصصبن بامنياز فى القفز على تحركات الآخرين، فما إن يلمح الشاكرية بوادر تحرك فئوى فى المجتم حتى ترافق جموعهم هذه التحركات للضغط على صانعى

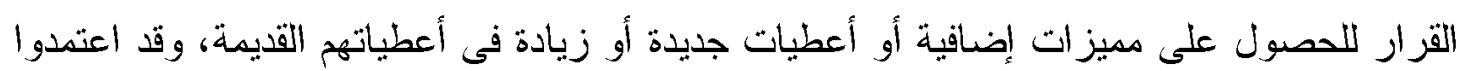

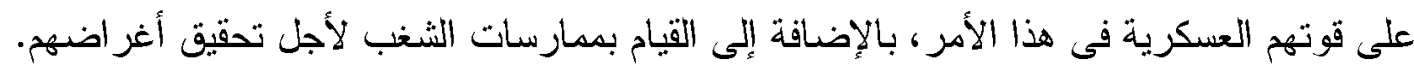
- - عانت عناصر الثناكرية من أزمة القيادة، فلم يُعرف الثاكرية أبدا القائد الواحد ولا القوة

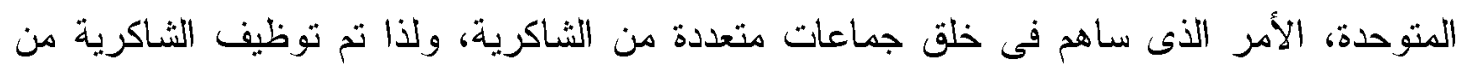
القوى السياسية المتناحرة كأداة لتصفية الخصوم السياسيين، وكأداة لتحقيق أجنداتهم السياسية المختلفة. وفى الأخير فإِنا أمام فئة تطورت من مجرد خدم فى البلاط إلى قوة عسكرية ذات طبيعة خاصة وصو لاً لمرتبة المشاركة فى صنع القزار السياسى، متعاملة ببرجماتية فلم تتبنى قضايا دينية أو فكرية أو سياسية حقفقية، وتحالفت مع الثىى وضده، ولم يعنيها سوى المكتسبات والدصالح

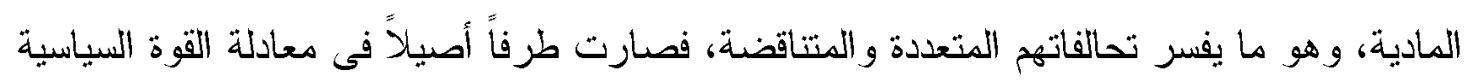
فى الدولة العباسبة فى القرن الثالث الهجرى. 
قائمة المصادر والمراجي

العهد القديم ، كتاب المقدس المشتفل على العهد العتيق الموجودة فى الأصل العبرانى وأيضاً كتاب

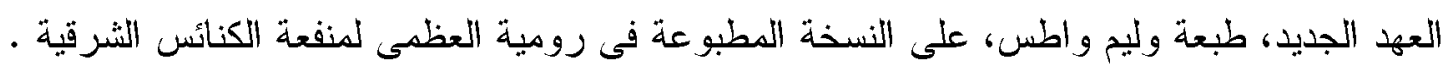
المصادر المطبوعة :

ابن الأثير" أبي الحسن علي بن أبي الكرم محد بن محمد بن عبدالكريم الثثيباني، ت (·r آهـ/ (a) Trut

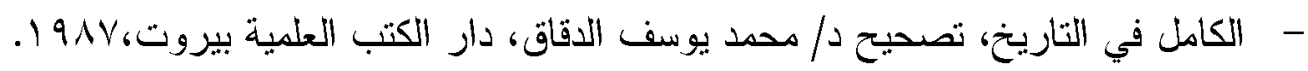

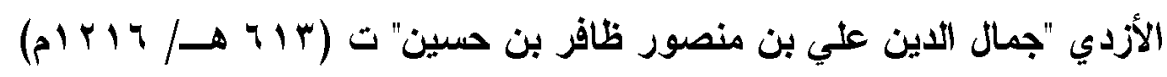

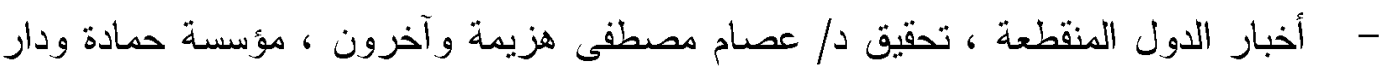

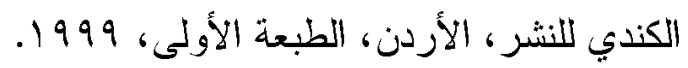

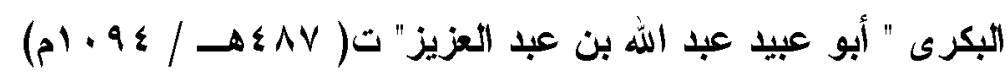

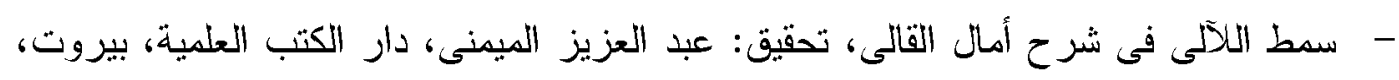
دت،

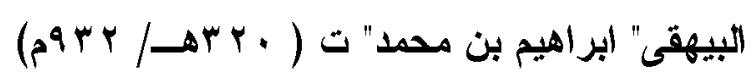

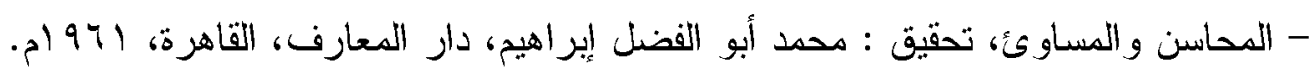

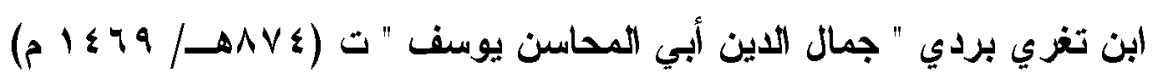

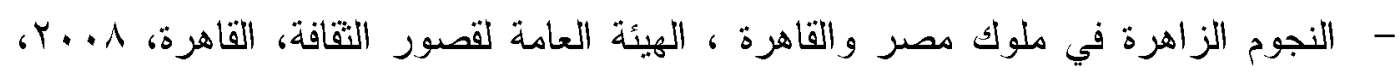

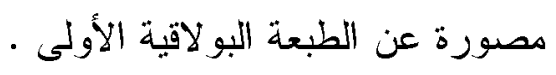

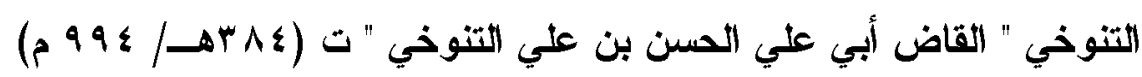

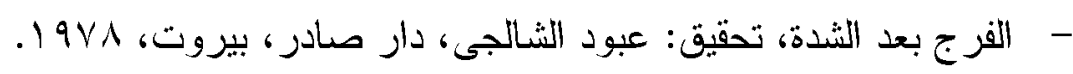

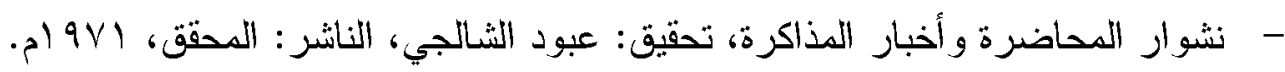

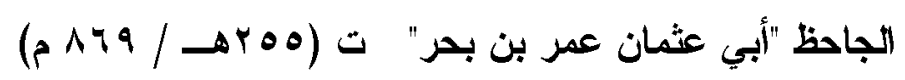

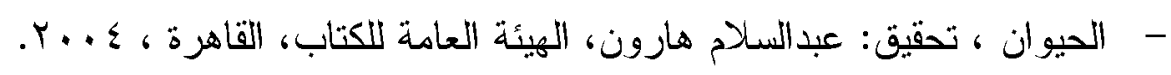

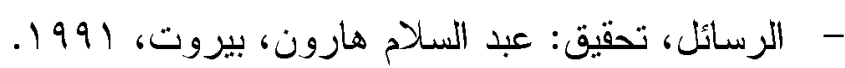

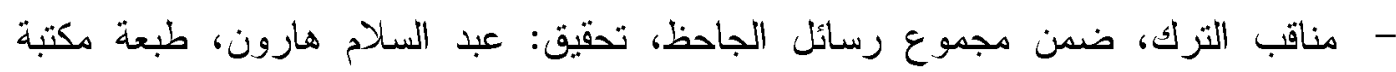

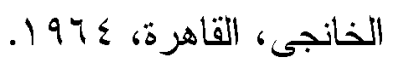




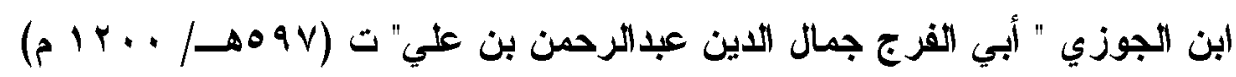

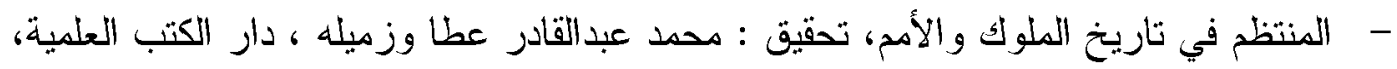

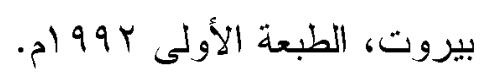

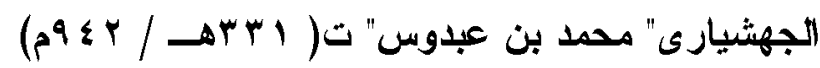

- نصوص ضائعة من كتاب الوزراء والكتاب، جمعها: ميخائيل عو اد، بيروت، 1970 - 1970

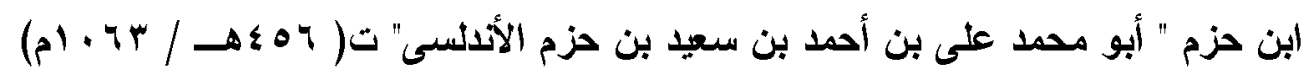

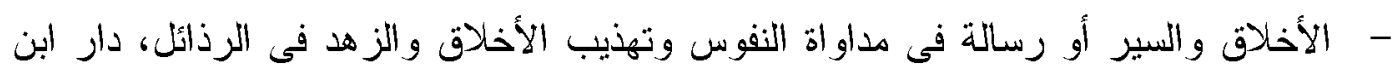

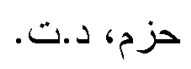

- رسائل ابن حزم، تحقيق: إحسان عباس، المؤسسة العربية للاراسات والنشر، بيروت،

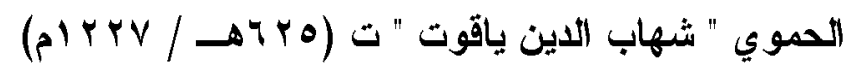

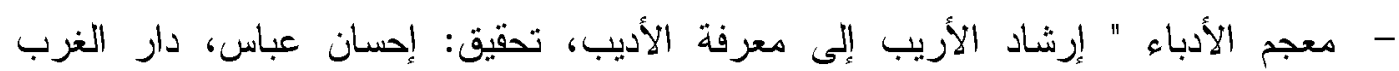

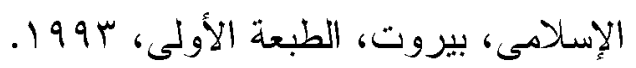

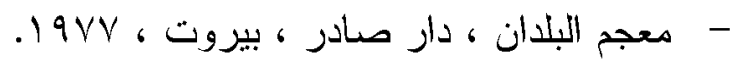

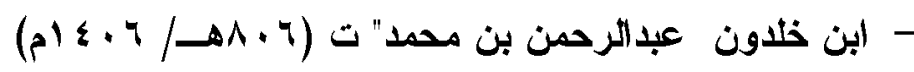

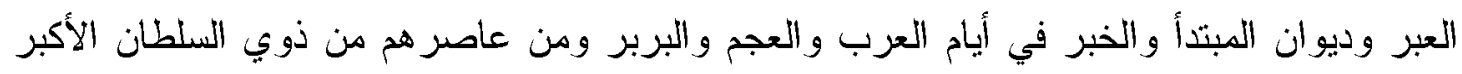

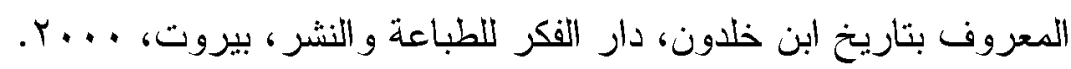

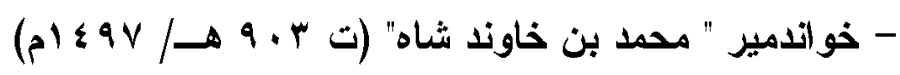
روضة الصفا في سيرة الأنبياء والملوك والخلفا" ترجمة عن الفارسية د/ أحمد عبدالقادر الثاذلي ،

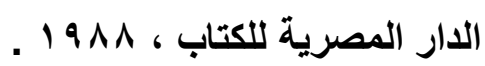

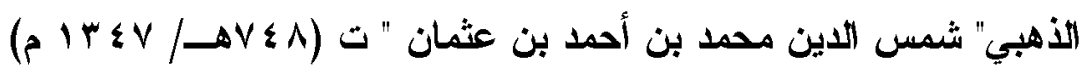

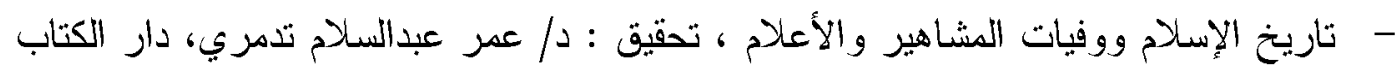

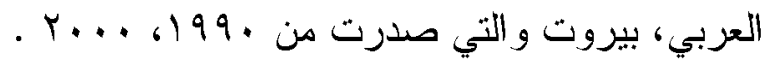

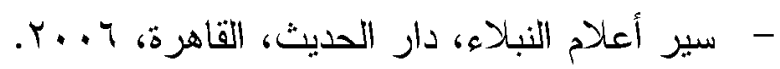

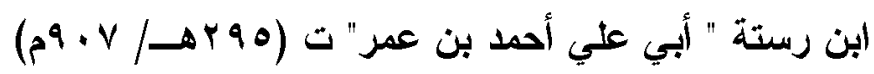

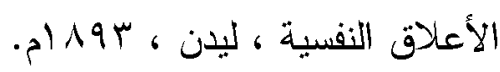

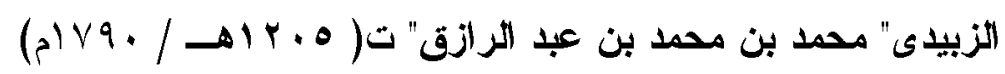
- تاج العروس من جواهر القاموس، دار الهداية، د.ت. 
ابن الزبير" القاضى الرشيد" ث( القرن الخامس الهجرى)

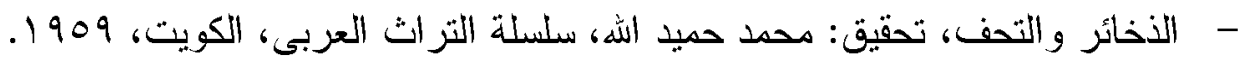

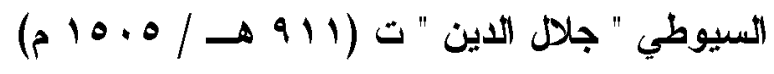

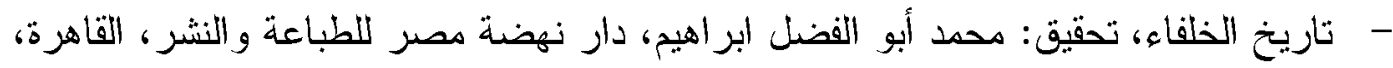

$.19 \vee 0$

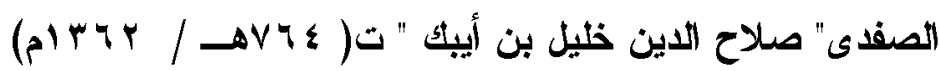

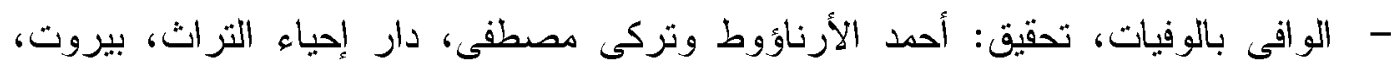
. . . . .

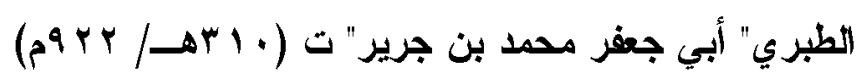

- تاريخ الرسل والملوك، تحقيق: محمد أبو الفضل إبراهيم، دار المعارف، القاهرة ، الطبعة

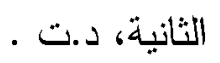

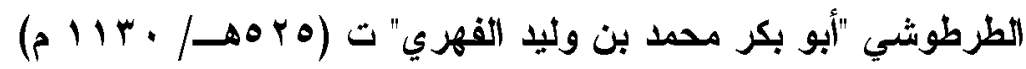

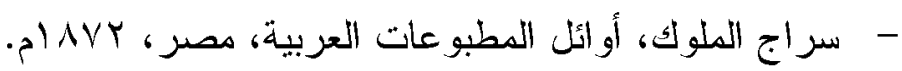

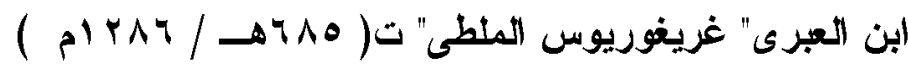

$$
\begin{aligned}
& \text { - - تاريخ مختصر الدول، بيروت، د.ت. }
\end{aligned}
$$

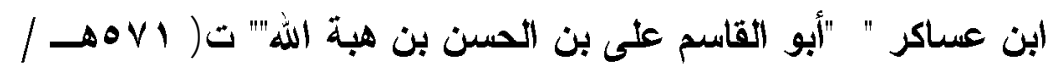

- تاريخ دمشق، تحقيق: عمرو بن غرامة العمروى، دار الفكر للطباعة والنشر، 1990.

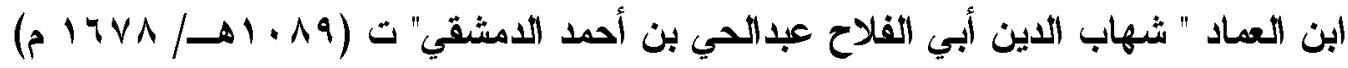

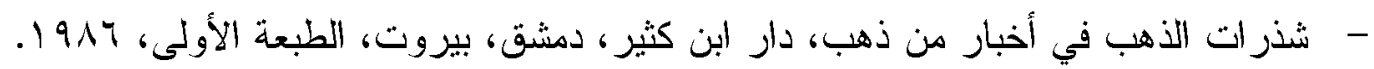

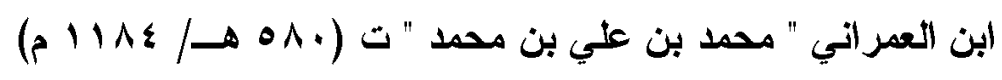
- الأنباء في تاريخ الخلفاء، تحقيق: د/ قاسم السامر ائي، دار الآفاق العربية، القاهرة،

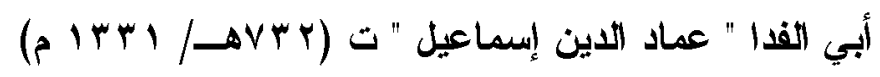

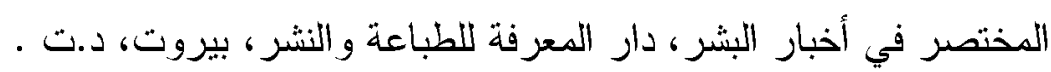

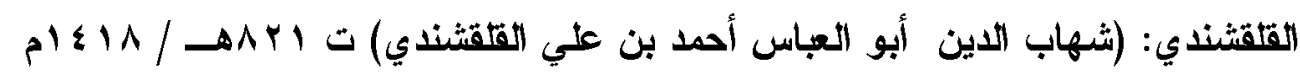

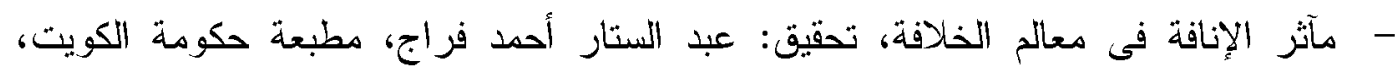

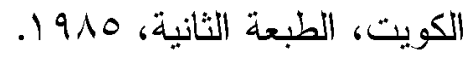




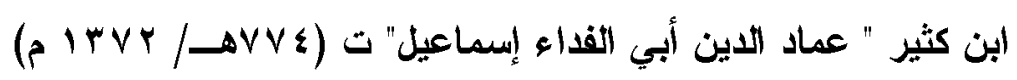
- البداية والنهاية، تحقيق : د / / عبداله بن عبدالمحسن، هجز للطباعة و النشر ، الطبعة الأولى،

$$
\text { . } 1991
$$

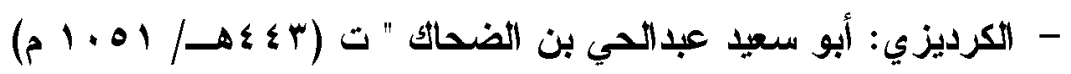

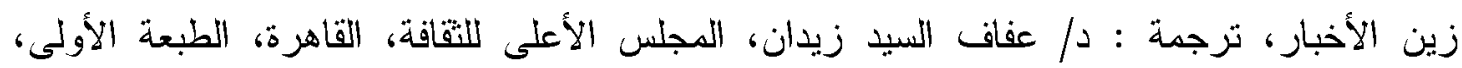

.r. . T

مجهول

- ألف لبلة وليلة، دار الكتب العمية، بيروت، د.ت.

مجهول

- سيرة الظاهر بيبرس، الهيئة العامة للكتاب، القاهرة، 1999.

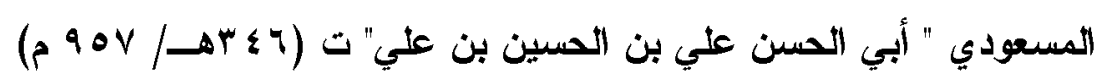

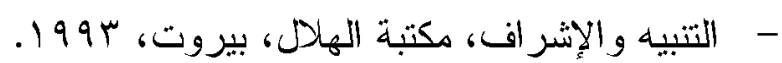

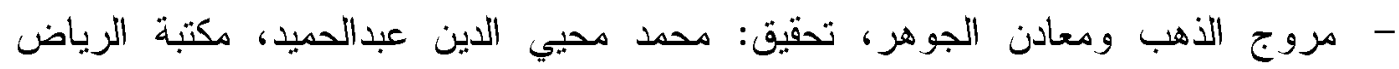

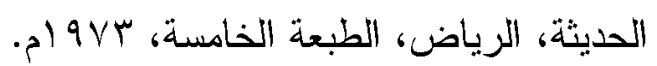

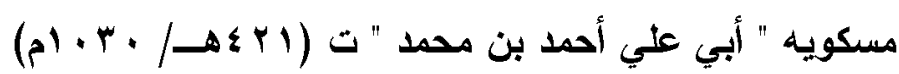

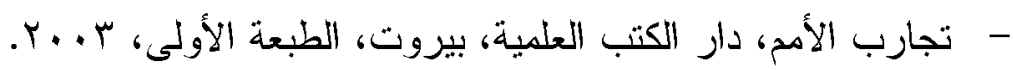

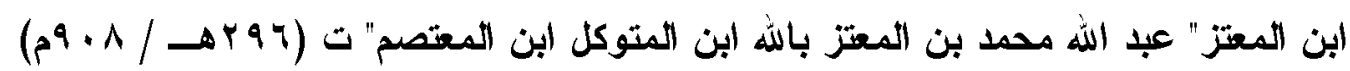

- البديع فى البديع ، دار الجيل، بيروت، الطبعة الأولى، .199.

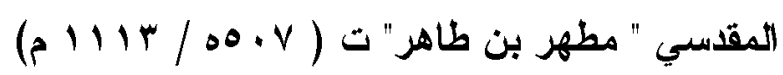

- البده والتاريخ، نشره لأول مرة وعلق عليه: كليمان هوار، الهيئة العامة للكتاب، القاهرة،

.r. . .

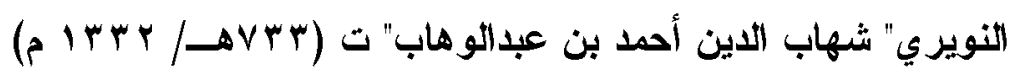

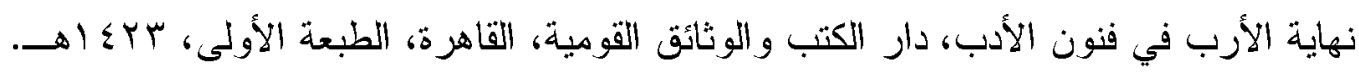

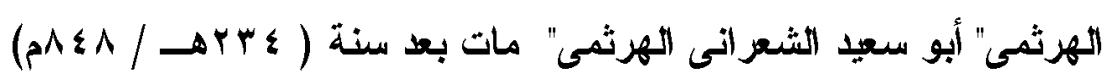

- مختصر سياسة الحرب، تحقيق: عبد الرؤوف عون، المؤسسة المصرية العامة للتأليف و الترجمة و الطباعة و النشر ، د.ت.

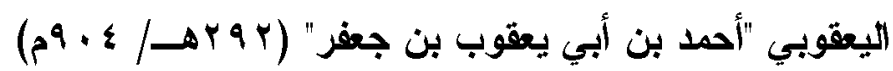

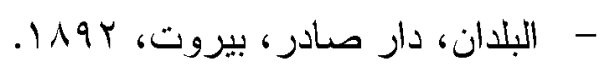




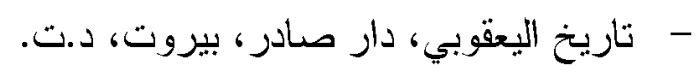

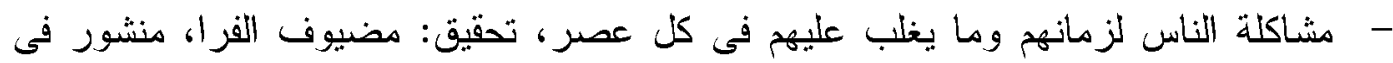

مجلة الوثائق و الدراسات الانسانية،جامعة قطر، السنة الخامسة، العدد الخامس، بـ بو 199 ـ.

\section{المر اجيع العريبة :}

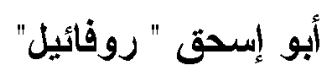

- أحوال نصارى بغداد فى عهن الخلافة العباسية، مطبعة شفيق بغداد، ـ197.

الألوسى"عادل محيى الدين" ( دكتور)

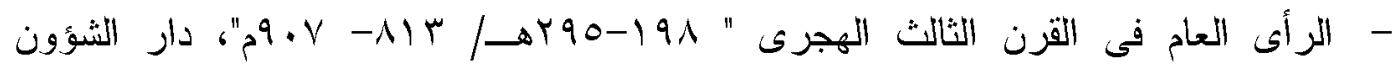

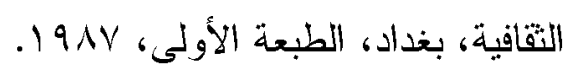

\section{الجنزورى" علية عبد السميع" ( دكتور)}

- الثغور البرية الإسلامية على حدود الدولة البيزنطية فى العصور الوسطى، الهيئة المصرية

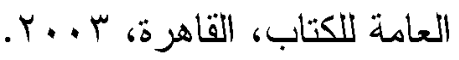

$$
\text { حافظ" صفاء" ( دكتور) }
$$

- - نظم الحكم فى الدولة العباسية من أو ائل القرن الثالث الهجزى إلى دخول بنى بويه بغداد،

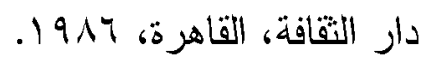

$$
\text { حيدر " محمد على" ( دكتور ) }
$$

- الدويلات الإسلامية فى المشرق، عالم الكتب، القاهرة، د.ت.

الخورى" سليم جبرائيل" و ، سليم ميخائيل شحاده

- INVV، آثار الأدهار - القسم التاريخ، المطبعة السورية، بيزوت،

$$
\text { السامر ائى " حسام الدين" ( دكتور) }
$$

- المؤسسات الإدارية فى الدولة العباسية، دار الفكر العزبى، الطبعة الثانية، د.ت. 


$$
\text { سعد " فهمى عبد الزرازق" ( دكتور) }
$$

- العامة فى بغداد فى القرنين الثالث و الرابع الهجريين"، الأهلية للنشر و التوزيع، بيروت،

$$
\text { أبو سيف" فتحى" ( دكتور) }
$$

- المشرق الإسلامى بين التبعية و الاستقلال، أولاً الطاهريون ( تاريخهم السياسى والحضارى)،

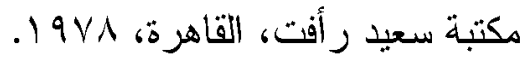

- خراسان تاريخها السياسى من سقوط الطاهريين إلى بداية الغزنويين، مكتبة سعيد رأفت،

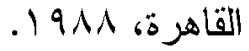

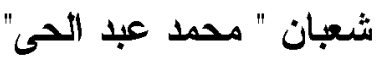

- الدولة العباسية ، الفاطميون، الأهلية للنشر والتوزيع، بيروت، 1911.

عبد الغتى" عارف أحمد"

- - ت تاريخ أمر اء المدينة المنورة، دار كنان، د.ت.

العزى " محمد فياض" ( دكتور)

- النزاع بين قادة الجيش الأتراك والخلافة العباسية فى ظل الفوضى العسكرية، دار الجنان

$$
\begin{aligned}
& \text { لللنشر و التوزيع، الأردن، د.ت. } \\
& \text { العلى" صالح أحمد" ( دكتور) }
\end{aligned}
$$

- معالم بغداد الإدارية و العمر انية، دار الثؤون الثقافية، بغداد، 911 -

$$
\text { فوزى" فاروق عمر" ( دكتور) }
$$

- تاريخ النظم الإِسلامية دراسة لتطور المؤسسات المركزية فى الدولة فى القرون الإسلامية

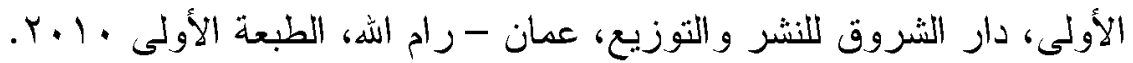

$$
\text { الكعبى " ضياء" ( دكتور ) }
$$

- السرد العربى القديم " الأنساق و إثكاليات التأويل، المؤسسة العربية للاراسات و النشر،

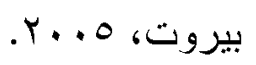


محمود " حسن أحمد" و أحمد الثريف ( دكتور)

- العالم الإسلامى فى العصر العباسى، دار الفكر العربى، القاهرة، د.ت.

المناصير" محمد عبد الحفيظ" ( دكتور)

- الجيش فى العصر العباسى الأول بسار- بسYهـ ،دار مجدولاوى للنشر، عمان-الأردن،

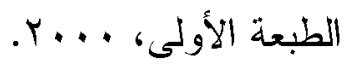

نورى " موفث سائم" ( دكتور)

- العامة و السلطة فى بغداد، دار الكتاب، دار المتنبى، الأردن ه . . .

المقالات والبحوث :

الجبيلى " علياء يحيى على" ( دكتور)

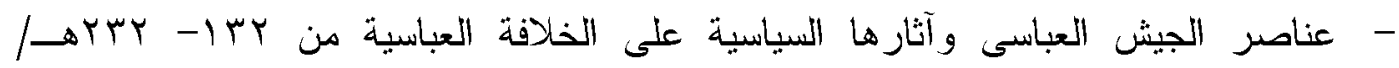



طلفاح" مضر عدنان" ( دكتور)

- بيعة الخليفة العباسى المتوكل على الله لأبنائه الثلاثة بولاية العهد فى عام| هبrهـــ

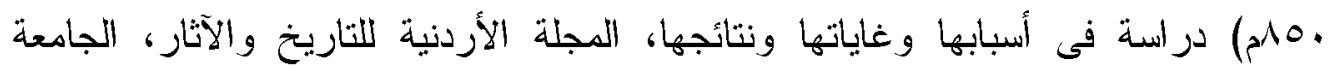

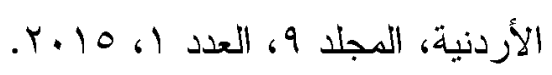

فياض" محمد" ( دكتور)

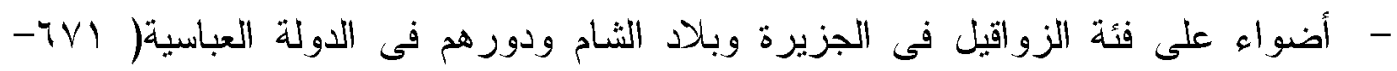

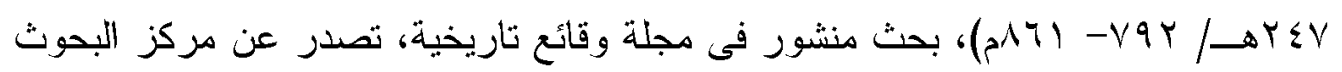

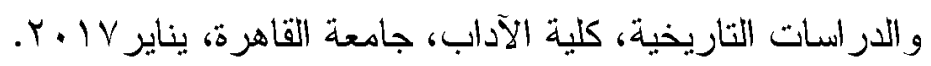

اللرسيائل البطمبة:

فويل" يوسف"

- تنظيمات الجيش فى العصر العباسى الأول، رسالة ماجستير غير منشورة المدرسة العليا

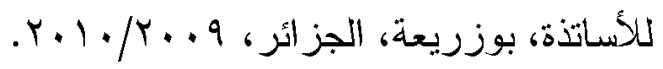


الكعبى" عثياء سائم بن أحمد بن حليس"

- الجيش العباسى تطوره وتتظيماته ( (1)-

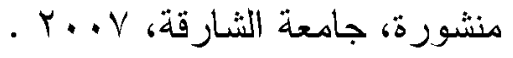

$$
\text { محروس " ريهان نجدى" }
$$

- عامة البصرة من منتصف القرن الثالث الهجرى حتى سقوط الخلافة العباسية، رسالة ماجستير غير منشورة، كلية الآداب، جامعة طنطا، V. . . .

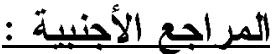

- KHALIL, ATHAMINA, AL-SHAKIRIYYA, The Encylopadeia of Islam, Vol. IX, Leiden, 1997. 